\title{
ANL-78-61
}

\section{EVALUATION OF CERAMIC REFRACTORIES FOR SLAGGING GASIFIERS: SUMMARY OF PROGRESS TO DATE}

by

C. R. Kennedy, R. Swaroop, D. J. Jones, R. J. Fousek, R. B. Poeppel, and D. Stahl

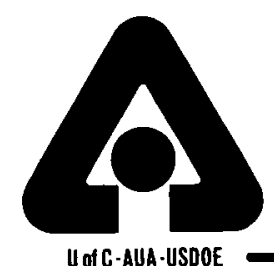

ARGONNE NATIONAL LABORATORY, ARGONNE, ILLINOIS Prepared for the U. S. DEPARTMENT OF ENERGY under Contract W-31-109-Eng-38 


\section{DISCLAIMER}

This report was prepared as an account of work sponsored by an agency of the United States Government. Neither the United States Government nor any agency Thereof, nor any of their employees, makes any warranty, express or implied, or assumes any legal liability or responsibility for the accuracy, completeness, or usefulness of any information, apparatus, product, or process disclosed, or represents that its use would not infringe privately owned rights. Reference herein to any specific commercial product, process, or service by trade name, trademark, manufacturer, or otherwise does not necessarily constitute or imply its endorsement, recommendation, or favoring by the United States Government or any agency thereof. The views and opinions of authors expressed herein do not necessarily state or reflect those of the United States Government or any agency thereof. 


\section{DISCLAIMER}

Portions of this document may be illegible in electronic image products. Images are produced from the best available original document. 
The facilities of Argonne National Laboratory are owned by the United States Government. Under the terms of a contract (W-31-109-Eng-38) between the U. S. Department of Energy, Argonne Universities Association and The University of Chicago, the University employs the staff and operates the Laboratory in accordance with policies and programs formulated, approved and reviewed by the Association.

\section{MEMBERS OF ARGONNE UNIVERSITIES ASSOCIATION}

The University of Arizona

Carnegie-Mellon University

Case Western Reserve University

The University of Chicago

University of Cincinnati

Illinois Institute of Technology

University of Illinois

Indiana University

lowa State University

The University of Iowa
Kansas State University The University of Kansas Loyola University Marquette University Michigan State University The University of Michigan University of Minnesota University of Missouri Northwestern University University of Notre Dame
The Ohio State University

Ohio University

The Pennsylvania State University

Purdue University

Saint Louis University

Southern Illinois University

The University of Texas at Austin

Washington University

Wayne State University

The University of Wisconsin

\section{NOTICE}

This report was prepared as an account of work sponsored by the United States Government. Neither the United States nor the United States Department of Energy, nor any of their employees, nor any of their contractors, subcontractors, or their employees, makes any warranty, express or implied, or assumes any legal liability or responsibility for the accuracy, completeness or usefulness of any information, apparatus, product or process disclosed, or represents that its use would not infringe privately-owned rights. Mention of commercial products, their manufacturers, or their suppliers in this publication does not imply or connote approval or disapproval of the product by Argonne National Laboratory or the U. S. Department of Energy.

Printed in the United States of America

Available from

National Technical Information Service

U. S. Department of Commerce

5285 Port Royal Road

Springfield, Virginia 22161

Price: Printed Copy $\$ 5.25$; Microfiche $\$ 3.00$ 
Distribution Category:

Coal Conversion and Utilization--

Materials and Components (UC-90h)

ANL-78-61

ARGONNE NATIONAL LABORATORY

9700 South Cass Avenue

Argonne, Illino is 60439

EVALUATION OF CERAMIC REFRACTORIES FOR SLAGGING GASIFIERS:

SUMMARY OF PROGRESS TO DATE

by

C. R. Kennedy, R. Swaroop, D. J. Jones, R. J. Fousek,

R. B. Poeppe1, and D. Stah1

Materials Science Division

September 1978

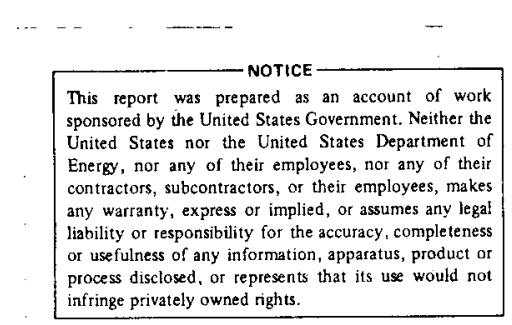

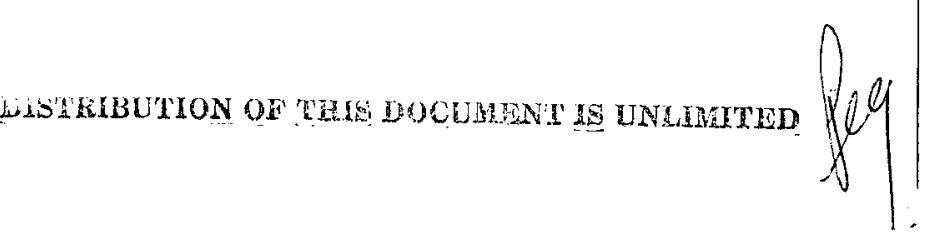


TABLE OF CONTENTS

$\underline{\text { Page }}$

ABSTRACT ........................... 7

I. INTRODUCTION . . . . . . . . . . . . . . . . 7

A. Objective .................... . 7

B. Scope ...................... . 7

C. Previous Reports ................... 8

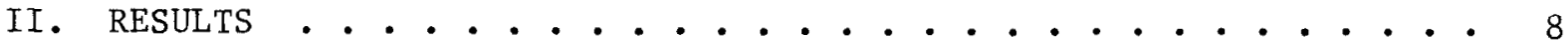

A. Corrosion Tests Without Water Cooling . . . . . . . . 8

B. Corrosion Tests With Water Cooling . . . . . . . . 18

III. SUMMARY ...................... 55

ACKNOWLEDGMENTS . . . . . . . . . . . . . . . . 55

REFERENCES . . . . . . . . . . . . . . . . . . . 55 
LIST OF FIGURES

No.

$\underline{\text { Title }}$

$\underline{\text { Page }}$

1. Schematic of the Slag-corrosion Furnace as Originally

Designed . . . . . . . . . . . . . . . . . . .

2. Cut Sections of the Fused-cast Refractories Exposed to Slag

Attack in Test Run 3.................... 17

3. Top and Side Views of the New Bottom Section of the Slag-

corrosion Furnace . . . . . . . . . . . . . . . .

4. Furnace Plenum Temperature and Midheight Brick Temperatures

$12.7 \mathrm{~mm}$ (0.5 in.) from the Hot Face of 3/4-1ength Bricks of

Each Composition During Test Run 4. . . . . . . . . . .

5. Midheight Temperatures in Bricks During Test Run 4 at Four Locations in Full-length Bricks and at Three Locations in 3/4- and 1/2-1ength Bricks .................

6. Cut Sections of the 3/4-1ength Refractories Exposed to Slag Attack in Test Run 4. . . . . . . . . . . . . . . 24

7. Maximum Depth of Removal as a Function of Brick Length for Silicon Oxynitride Refractory Bricks Exposed in Test Run 4....

8. Furnace P1enum Temperature and Midheight Brick Temperatures $38.1 \mathrm{~mm}$ (1.5 in.) from the Hot Face of Magnesia-Chrome 3/4-1ength Refractory Bricks During Test Run 5.........

9. Midheight Temperatures in Direct-bonded Magnesia-Chrome Bricks During Test Run 5 at Four Locations in Full-1ength Bricks and at Three Locations in 3/4- and 1/2-1ength Bricks . . . . . . .

10. Cut Sections of the Full-1ength Refractories Exposed to Slag Attack in Test Run 5... . . . . . . . . . . . .

11. Furnace Plenum Temperature and Midheight Brick Temperatures $38.1 \mathrm{~mm}$ from the Hot Face of 3/4-1ength Bricks of Each

Composition During Test Run 6 . . . . . . . . . . . .

12. Midheight Temperatures in Bricks During Test Run 6 at Four Locations in Full-1ength Bricks and at Three Locations in 3/4- and 1/2-length Bricks . . . . . . . . . . . . .

13. Cut Sections of the 3/4-length Refractories Exposed to Slag

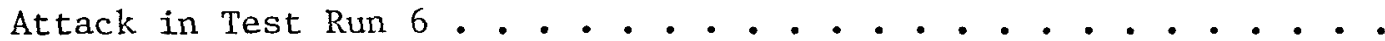

14. Furnace Plenum Temperature and Midheight Brick Temperatures $12.7 \mathrm{~mm}$ ( $0.5 \mathrm{in.})$ from the Hot Face of 3/4-1ength Bricks of Each Composition During Test Run 7............. 
LIST OF FIGURES

No. Title

$\underline{\text { Page }}$

15. Midheight Temperatures in Bricks During Test Run 7 at Four

Locations in Full-length Bricks and at Three Locations in

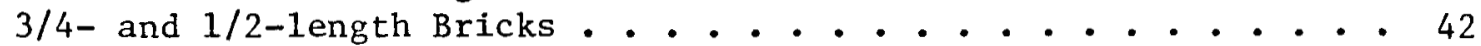

16. Cut Sections of the 3/4-1ength Refractories Exposed to Slag

Attack in Test Run 7... . . . . . . . . . . . . 43

17. Posttest Photograph Showing the Placement of the Standard

Specimen of Refractory Number 2 in Test Run 8 . . . . . . . 45

18. Furnace Plenum Temperature and Midheight Brick Temperatures

$38.1 \mathrm{~mm}$ (1.5 in.) from the Hot Face of Full-1ength Bricks of

Each Composition During Test Run 8... . . . . . . . 47

19. Midheight Brick Temperature Versus Distance from Hot Face

in Test Run 8 with Furnace Plenum Temperature $=1610^{\circ} \mathrm{C}$. . . . 48

20. Midheight Brick Temperature Versus Distance from Hot Face

in Test Run 8 with Furnace Plenum Temperature $=1520^{\circ} \mathrm{C}$. . . . 50

21. Cut Sections of Ful1-length Refractories Exposed to Slag

Attack in Test Run 8... . . . . . . . . . . 52

22. Cut Sections of Refractories Exposed to Slag Attack in

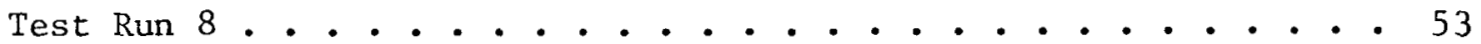

23. Posttest Photograph of the Standard Specimen of Refractory

Number 2 That Was Partially Immersed in the Slag Bath

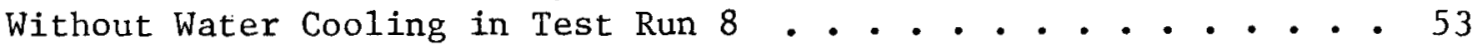

24. Schematic of the Plasma Torch Materials Testing Facility . . . . 54 


\section{LIST OF TABLES}

No.

$\underline{\text { Title }}$

$\underline{\text { Page }}$

I. Slag Composition During Test Run I . . . . . . . . . . 10

II. Relative Corrosion Resistance of Refractories Exposed to

Slag Attack in Test Run 1............... 11

III. Slag Composition During Test Run 2. . . . . . . . . 12

IV. Relative Corrosion Resistance of Refractories Exposed to Slag Attack in Test Run 2 . . . . . . . . . . . . . 14

V. Slag Composition During Test Run 3... . . . . . . . 15

VI. Relative Corrosion Resistance of Refractories Exposed to Slag Attack in Test Run 3 . . . . . . . . . . . . 16

VII. Slag Composition During Test Run 4 . . . . . . . . . . 20

VIII. Relative Corrosion Resistance of Refractories Exposed to Slag Attack in Test Run 4. . . . . . . . . . . . 25

IX. Slag Composition During Test Run 5. . . . . . . . . . 29

X. Relative Corrosion Resistance of Refractories Exposed to Slag Attack in Test Run 5.............. 30

XI. Slag Composition During Test Run 6 . . . . . . . . . 33

XII. Relative Corrosion Resistance of Refractories Exposed to Slag Attack in Test Run 6. . . . . . . . . . . . 34

XIII. Slag Composition During Test Run 7 . . . . . . . . . . 39

XIV. Relative Corrosion Resistance of Refractories Exposed to Slag Attack in Test Run 7... . . . . . . . . . 40

XV. Relative Corrosion Resistance of Refractories Exposed to Slag Attack in Test Run 8 . . . . . . . . . . . 44 


\section{EVALUATION OF CERAMIC REFRACTORIES FOR SLAGGING GASIFIERS: SUMMARY OF PROGRESS TO DATE}

by

C. R. Kennedy, R. Swaroop, D. J. Jones, R. J. Fousek, R. B. Poeppe1, and D. Stahl

ABSTRACT

Commercial refractories were tested for up to $500 \mathrm{~h}$ in both basic and acidic slags. The slag compositions typify those expected in slagging coal gasifiers. The slag temperatures ranged up to $1600^{\circ} \mathrm{C}$. Compositions tested have included silicon carbides, chrome-alumina-magnesia spinels, and alumina and magnesia-based refractories with various amounts of chromia and silica. In some tests, the cold faces were water cooled. With water cooling, the silicon carbides showed virtually no attack after $500 \mathrm{~h}$. In the absence of water cooling, the chrome-alumina-magnesia spinels were the most resistant to slag attack but were subject to thermal-shock cracking. Alumina-chrome refractories performed well in acid slags when water cooled, are probably more stable than silicon carbide in coal-gasification atmospheres, and, in the form of ramming mixes, showed excellent thermal-shock resistances. Plans for future testing are described.

\section{INTRODUCTION}

\section{A. Objective}

The overall objectives of this program are to (a) determine, on the basis of laboratory tests under prototypic conditions, which commercial refractories can best withstand the conditions expected in slagging coalconversion systems, (b) establish which refractory structure-bond systems have potential for improved performance under a slagging environment, and (c) work with commercial refractory suppliers to improve the potential of their refractories for coal-conversion plant use.

\section{B. Scope}

Refractory bricks supplied by commercial vendors are being evaluated for use in coal-conversion plants where slagging conditions exist. A variety of refractory compositions have been exposed to both basic and acidic slags. The most promising of these have been selected for further testing under prototypic thermal gradients established by use of water cooling. Posttest metallography and scanning-electron microscopy (SEM) are being utilized to determine the attack mechanisms. Refractory selection and evaluation are based on chemical compatibility, suitable abrasive, mechanical, and thermal properties, ease of fabrication, and cost. 
C. Previous Reports

The complete set of quarterly reports detailing the progress of this study at Argonne National Laboratory are:

$\begin{array}{ll}\text { ANL-76-7 } & \text { July-September 1975 } \\ \text { ANL-76-22 } & \text { October-December 1975 } \\ \text { ANL-76-60 } & \text { January-March 1976 } \\ \text { ANL-76-111 } & \text { April-June 1976 } \\ \text { ANL-76-125 } & \text { July-September 1976 } \\ \text { ANL-77-5 } & \text { October-December 1976 } \\ \text { ANL-77-41 } & \text { January-March 1977 } \\ \text { ANL-77-62 } & \text { April-June 1977 } \\ \text { ANL-78-6 } & \text { July-December 1977 } \\ \text { ANL-78-54 } & \text { January-March 1978 }\end{array}$

II. RESULTS

\section{A. Corrosion Tests Without Water Cooling}

Figure 1 shows a schematic of the slag-corrosion furnace as originally designed. The rotating sample holder in the center of the furnace was dismantled after repeated failures, and the refractories to be tested were embedded in the wall of the furnace. The refractory samples tested without water cooling (test runs 1-3) were $65-75 \mathrm{~mm}$ long and $0110 \mathrm{~mm}$ (4-1/2 in.) wide.

For the first run, a North Dakota 1ignite slag with a base-to-acid $(B / A)$ ratio of 0.5 was charged into the furnace so that the level of slag reached approximately the midheight of the test bricks. The temperature in the furnace plenum was maintained at $1450-1500^{\circ} \mathrm{C}$ for $200 \mathrm{~h}$ with an oxygen partial pressure of $\sim 10^{-2} \mathrm{~Pa}$. During the run, three shutdowns to $<500^{\circ} \mathrm{C}$ occurred. The variation in slag composition with time during test run 1 is shown in Table $\mathrm{I}$. Table II lists the relative corrosion resistances of 15 refractories tested. These data are reported in terms of the maximum abraded (or eroded) depth of the refractory and the normalized material loss. This table also 1ists the maximum depth of visible slag penetration into the refractory. The minimum and maximum material losses were observed in refractories 22 and 7 , respectively. Refractories 4,12,15-17, and 19-22 showed fairly good corrosive and abrasive resistance to the slag. Refractories 4, 14, 18, and 22 developed cracks during the run. The development of cracks in the fused-cast dense refractories ( 4 and 22) as a result of the thermal cycling was expected. Refractories 7 and 8 , which are castable refractories, disintegrated badly and showed a large materials loss during the run.

In test run 2, 17 refractories were exposed to slag attack for $500 \mathrm{~h}$ at $1500^{\circ} \mathrm{C}$ and an oxygen partial pressure of $\sim 10^{-3} \mathrm{~Pa}$. The slag composition, which again varied as a function of time, is shown in Table III. The slag was slightly acidic for the first $\sim 150 \mathrm{~h}(\mathrm{~B} / \mathrm{A}=0.85)$, but quite basic (B/A 1.5 ) for the last $\sim 340 \mathrm{~h}$, probably as the result of mullite and alumina precipitation at the lower and outside edges of the slag pool, which are cooler than the center. The time-averaged $\mathrm{B} / \mathrm{A}$ ratio was 1.35 . 

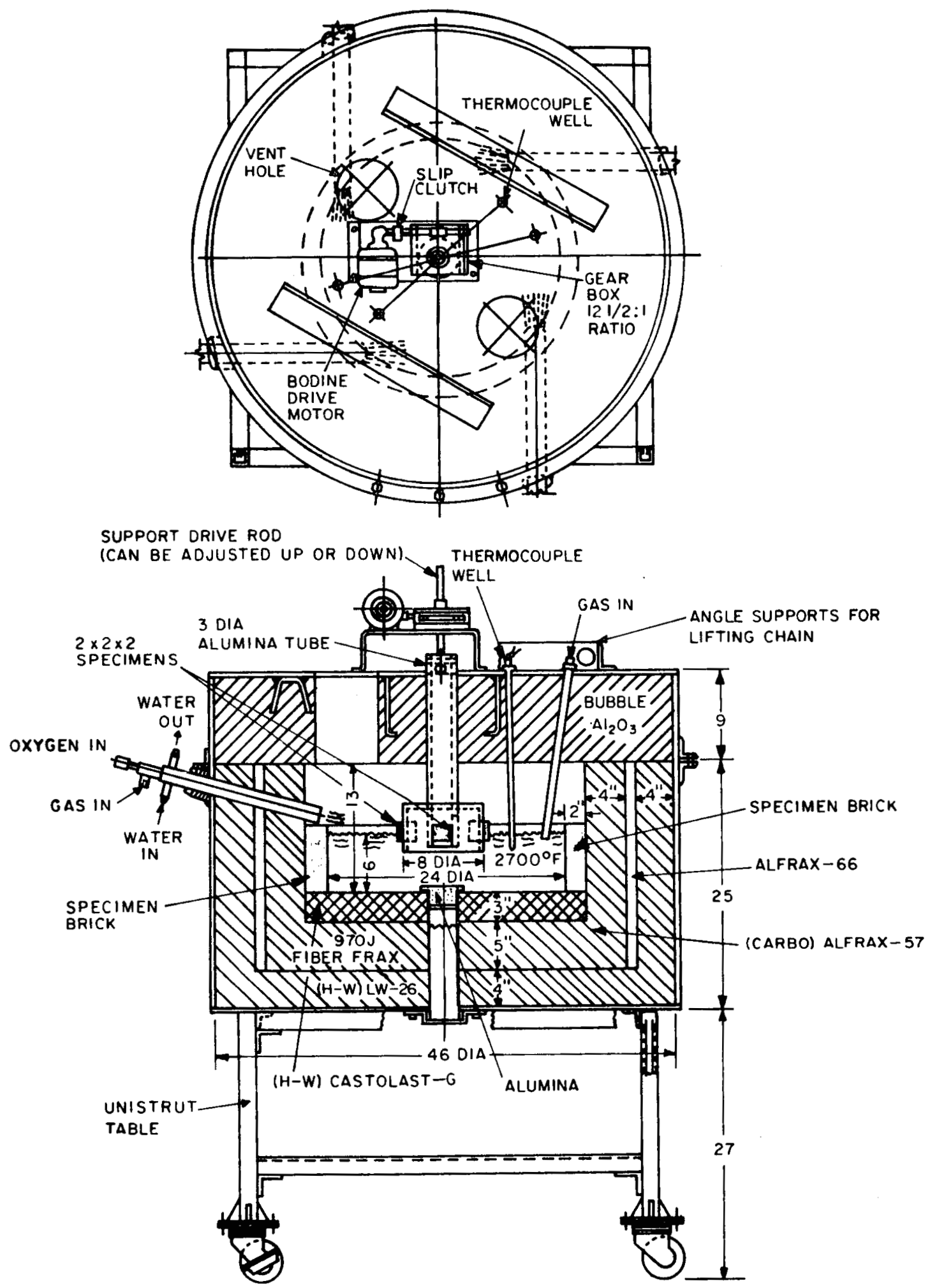

Fig. 1. Schematic of the Slag-corrosion Furnace as Originally Designed. The rotating sample holder in the center of the furnace was dismantled after repeated failures. ANL Neg. No. 306-78-767. 
TABLE I. Slag Composition During Test Run 1

\begin{tabular}{|c|c|c|c|c|}
\hline & & \multicolumn{3}{|c|}{ Exposure Time, $\mathrm{h}$} \\
\hline \multicolumn{2}{|c|}{ Component } & 0 & 55 & 201 \\
\hline $\mathrm{Al}_{2} \mathrm{O}_{3}$ & (A) & $17.2^{\mathrm{a}}$ & 24.0 & 26.1 \\
\hline $\mathrm{SiO}_{2}$ & (S) & 50.2 & 46.0 & 47.2 \\
\hline $\mathrm{TiO}_{2}$ & $(\mathrm{~T})$ & 0.8 & 0.8 & 0.7 \\
\hline $\mathrm{CaO}$ & (C) & 13.2 & 12.2 & 13.0 \\
\hline $\mathrm{MgO}$ & $(M)$ & 4.8 & 4.7 & 3.9 \\
\hline $\mathrm{Na}_{2} \mathrm{O}+\mathrm{K}_{2} \mathrm{O}$ & $(N+K)$ & $3-6$ & $3-6$ & 2.4 \\
\hline $\mathrm{Fe}_{2} \mathrm{O}_{3}$ & (F) & 11.0 & 9.7 & 8.1 \\
\hline $\mathrm{SO}_{3}$ & - & 0.02 & 0.01 & $<0.01$ \\
\hline $\mathrm{P}_{2} \mathrm{O}_{5}$ & (P) & 0.10 & 0.09 & 0.07 \\
\hline $\mathrm{V}_{2} \mathrm{O}_{5}$ & $(\mathrm{~V})$ & 0.05 & 0.04 & 0.04 \\
\hline B/A Ratiob & & 0.49 & 0.44 & 0.40 \\
\hline
\end{tabular}


TABLE II. Relative Corrosion Resistance of Refractories Exposed to Slag Attack in Test Run 1

\begin{tabular}{|c|c|c|c|c|c|}
\hline Number & Composition & Bond & $\begin{array}{l}\text { Normalized } \\
\text { Material } \\
\text { Lost, } \\
\text { vol } \%\end{array}$ & $\begin{array}{c}\text { Maximum } \\
\text { Depth of } \\
\text { Penetration, } \\
\mathrm{mm}\end{array}$ & $\begin{array}{l}\text { Maximum } \\
\text { Depth of } \\
\text { Removal, } \\
\quad \mathrm{mm}\end{array}$ \\
\hline 1 & $\mathrm{Al}_{2} \mathrm{O}_{3}(99)$ & Sintered & 6.4 & 49 & 16 \\
\hline 4 & $\mathrm{Al}_{2} \mathrm{O}_{3}(99)$ & Fused-cast & 0.7 & 4 & 3 \\
\hline 7 & $\mathrm{Al}_{2} \mathrm{O}_{3}(95)-\mathrm{CaO}(5)$ & Chemical & 22.2 & 78 & 27 \\
\hline 8 & $\mathrm{Al}_{2} \mathrm{O}_{3}(94)-\mathrm{CaO}(5)$ & Chemical & 21.4 & 57 & 24 \\
\hline 10 & $\mathrm{Al}_{2} \mathrm{O}_{3}{ }^{(93)-\mathrm{P}_{2} \mathrm{O}_{5}(6)}$ & Chemical & 7.1 & 50 & 20 \\
\hline 12 & $\mathrm{Al}_{2} \mathrm{O}_{3}(90)-\mathrm{SiO}_{2}(9)$ & Sintered & 3.0 & 12 & 10 \\
\hline 14 & $\mathrm{Al}_{2} \mathrm{O}_{3}(91)-\mathrm{SiO}_{2}(8)$ & Sintered & 2.7 & 20 & 12 \\
\hline 15 & $\mathrm{Al}_{2} \mathrm{O}_{3}(91)-\mathrm{SiO}_{2}(8)$ & Sintered & 1.9 & 12 & 7 \\
\hline 16 & $\mathrm{Al}_{2} \mathrm{O}_{3}(89)-\mathrm{Cr}_{2} \mathrm{O}_{3}(10)$ & Sintered & 1.1 & 20 & 5 \\
\hline 17 & $\mathrm{Al}_{2} \mathrm{O}_{3}(84)-\mathrm{SiO}_{2}(9)-\mathrm{P}_{2} \mathrm{O}_{5}(4)$ & Chemical & 1.9 & 25 & 7 \\
\hline 18 & $\begin{aligned} \mathrm{Cr}_{2} \mathrm{O}_{3}(40) & -\mathrm{Fe}_{2} \mathrm{O}_{3}(23) \\
& -\mathrm{Al}_{2} \mathrm{O}_{3}(21)-\mathrm{MgO}(10)\end{aligned}$ & Chemical & 21.35 & $\mathrm{~b}$ & 21 \\
\hline 19 & $\begin{aligned} \mathrm{MgO}(53) & -\mathrm{Cr}_{2} \mathrm{O}_{3}(20) \\
& -\mathrm{Al}_{2} \mathrm{O}_{3}(17)-\mathrm{Fe}_{2} \mathrm{O}_{3}(8)\end{aligned}$ & Sintered & 2.7 & 21 & 8 \\
\hline 20 & $\begin{array}{l}\mathrm{MgO}(59)-\mathrm{Cr}_{2} \mathrm{O}_{3}(19) \\
-\mathrm{AI}_{2} \mathrm{O}_{3}(13)-\mathrm{Fe}_{2} \mathrm{O}_{3}(7)\end{array}$ & Sintered & 2.6 & 20 & 7 \\
\hline 21 & $\begin{aligned} \mathrm{MgO}(64) & -\mathrm{Cr}_{2} \mathrm{O}_{3}(15) \\
& -\mathrm{Al}_{2} \mathrm{O}_{3}(13)-\mathrm{Fe}_{2} \mathrm{O}_{3}(6)\end{aligned}$ & Sintered & 1.6 & 22 & 7 \\
\hline 22 & $\mathrm{Cr}_{2} \mathrm{O}_{3}(80)-\mathrm{MgO}(8)-\mathrm{Fe}_{2} \mathrm{O}_{3}(6)$ & Fused-cast & $\sim 0$ & $\sim_{0}$ & $\sim_{0}$ \\
\hline
\end{tabular}

${ }^{a}$ Measured from the original hot face.

${ }^{b}$ Complete attack. 
TABLE III. Slag Composition During Test Run 2

\begin{tabular}{|c|c|c|c|c|c|c|c|c|}
\hline \multirow[b]{2}{*}{ Component } & \multicolumn{8}{|c|}{ Exposure Time, $\mathrm{h}$} \\
\hline & $0^{a}$ & 86 & 158 & 186 & 278 & 375 & 422 & 494 \\
\hline $\mathrm{A}_{2} \mathrm{O}_{3}$ & $13.76^{\mathrm{b}}$ & 21.25 & 15.9 & 13.60 & 15.20 & 15.30 & 15.40 & 13.44 \\
\hline $\mathrm{CaO}$ & 34.0 & 31.96 & 39.60 & 41.0 & 38.46 & 36.56 & 39.52 & 37.18 \\
\hline $\mathrm{SiO}_{2}$ & 39.20 & 28.75 & 22.90 & 24.20 & 25.56 & 26.04 & 23.68 & 25.26 \\
\hline $\mathrm{SO}_{3}$ & 0.106 & 0.025 & 0.035 & 0.037 & 0.022 & 0.022 & 0.025 & 0.025 \\
\hline $\mathrm{Fe}_{2} \mathrm{O}_{3}$ & 6.97 & 7.01 & 10.17 & 8.86 & 9.73 & 8.54 & 10.06 & 10.39 \\
\hline $\mathrm{MgO}$ & 3.62 & 5.82 & 8.84 & 9.54 & 8.85 & 8.68 & 9.26 & 9.28 \\
\hline $\mathrm{K}_{2} \mathrm{O}+\mathrm{Na}_{2} \mathrm{O}$ & $0.5-1.5$ & $0.5-1.5$ & $0.5-1.5$ & $0.5-1.5$ & $0.5-1.5$ & $0.5-1.5$ & $0.5-1.5$ & $0.5-1.5$ \\
\hline $\mathrm{TiO}_{2}$ & 0.46 & 0.35 & 0.37 & 0.30 & 0.31 & 0.31 & 0.31 & 0.30 \\
\hline $\mathrm{V}_{2} \mathrm{O}_{5}$ & 0.03 & 0.03 & 0.01 & 0.02 & 0.02 & 0.01 & 0.05 & 0.05 \\
\hline B/A Ratio ${ }^{c}$ & 0.85 & 0.91 & 1.52 & 1.58 & 1.41 & 1.52 & 1.52 & 1.49 \\
\hline
\end{tabular}

${ }^{\mathrm{a}} \mathrm{S}$ lag composition was adjusted after $72 \mathrm{~h}$.

$\mathrm{b}_{\text {Wt } \% \text {. }}$

${ }^{\mathrm{C}}$ As in Table $\mathrm{I}$. 
The results of run 2 are presented in Table IV. Of the three highalumina sinter-bonded refractories, on ly the alumina-chrome and the $97.6 \%-$ alumina specimens exhibited small penetration and abrasion depths. The magnesia-chrome specimens performed well, but the silicon carbide types performed poorly. The problem with the latter was the small thermal gradient across the specimen in this test $(~(1 / 3$ to $1 / 2$ of the gradient in later watercooled tests). The phosphate-bonded aluminas, with the possible exception of the specimen that contains chrome, were almost completely penetrated by the slag. The best corrosion resistance of all the bricks tested in run 2 was exhibited by the fused-cast $\mathrm{Cr}_{2} \mathrm{O}_{3}-\mathrm{MgO}_{-}-\mathrm{Fe}_{2} \mathrm{O}_{3}$ spinel (number 22). It is evident that little corrosion or penetration of this spinel brick has occurred.

The third test run exposed 16 refractory bricks to slag attack for $500 \mathrm{~h}$ at $1500^{\circ} \mathrm{C}$ and an oxygen partial pressure of $\sim 10^{-3} \mathrm{~Pa}$. Table $\mathrm{V}$ lists the slag chemistry as a function of time throughout the test. As initially formulated, the slag was basic, with a B/A ratio of 1.25 . As the test proceeded, substantial amounts of alumina, apparently from the furnace bottom (and several chunks of high-alumina refractory that spalled from the roof), dissolved into the slag and caused the slag to become acidic in nature between 3 and $188 \mathrm{~h}(\mathrm{~B} / \mathrm{A}=0.79)$. Slow dissolution of alumina continued through the test until the $B / A$ ratio was 0.65 at $532 \mathrm{~h}$. The time-averaged $\mathrm{B} / \mathrm{A}$ ratio was 0.81 .

The refractories tested in run 3 are identified and their relative corrosion resistance summarized in Table VI. The sintered magnesia-chrome spinel and alumina-chrome specimens exhibited relatively small volume losses and depths of removal despite significant slag penetration. The aluminasilica and alumina-zirconia-silica bricks performed poorly, as did a silicon oxynitride brick. Figure 2 shows the three fused-cast refractories after exposure to the slag in test run 3. The alumina-zirconia-silica brick (number 65) was completely dissolved at the slag line; the alumina refractory showed significant removal, whereas the fused-cast $\mathrm{Cr}_{2} \mathrm{O}_{3}-\mathrm{MgO}-\mathrm{Fe}_{2} \mathrm{O}_{3}$ spinel. brick exhibited negligible interaction with the slag.

Comparison between the results of runs 2 and 3 for the four bricks tested in both runs $(19,20,22$, and 24$)$ indicates that the volume losses and depths of removal are similar despite a wide variation in final slag chemistry, e.g., $\mathrm{B} / \mathrm{A}=1.5$ for run 2 and 0.65 for run 3 .

To obtain thermal-gradient data across the brick specimens during test run 3 , holes were drilled radially from the steel shell to the cold face of three bricks. These bricks encompassed a range in thermal conductivity from low (alumina-zirconia-silica and magnesia-chrome) to high (silicon oxynitride). The average measured thermal gradients between the hot and cold faces ranged from 200 to $250^{\circ} \mathrm{C}$ during the first $100 \mathrm{~h}$ of run 3 . Calculations indicate that these gradients are $1 / 3$ to $1 / 2$ of the gradient calculated for a similar radial position of a $230-\mathrm{mm}$ (9-in.) wedge brick with a water-cooled cold face. 
TABLE IV. Relative Corrosion Resistance of Refractories Exposed to Slag Attack in Test Run 2

\begin{tabular}{|c|c|c|c|c|c|}
\hline Number & Composition & Bond & $\begin{array}{l}\text { Normalized } \\
\text { Material } \\
\text { Lost, } \\
\text { vol \% }\end{array}$ & $\begin{array}{c}\text { Maximum } \\
\text { Depth of } \\
\text { Penetration, } \\
\text { mm }\end{array}$ & $\begin{array}{l}\text { Maximum } \\
\text { Depth of } \\
\text { Removal, } \\
\mathrm{mm}\end{array}$ \\
\hline 1 & $\mathrm{Al}_{2} \mathrm{O}_{3}(99)$ & Sintered & 28.4 & 64 & 57 \\
\hline 25 & $\mathrm{Al}_{2} \mathrm{O}_{3}(99.5)$ & Sintered & 9.4 & 76 & $\sim 25$ \\
\hline 16 & $\mathrm{Al}_{2} \mathrm{O}_{3}(90)-\mathrm{Cr}_{2} \mathrm{O}_{3}(10)$ & Sintered & 8.2 & $\sim 25$ & $\sim 10$ \\
\hline 19 & $\begin{array}{c}\mathrm{MgO}(53)-\mathrm{Cr}_{2} \mathrm{O}_{3}(20)-\mathrm{Al}_{2} \mathrm{O}_{3}(17) \\
-\mathrm{Fe}_{2} \mathrm{O}_{3}(8)\end{array}$ & Sintered & 2.3 & $\sim 10$ & $\sim 5$ \\
\hline 20 & $\begin{aligned} \mathrm{MgO}(59) & -\mathrm{Cr}_{2} \mathrm{O}_{3}(19)-\mathrm{Al}_{2} \mathrm{O}_{3}(13) \\
& -\mathrm{Fe}_{2} \mathrm{O}_{3}(7)\end{aligned}$ & Sintered & 1.6 & $\sim 10$ & $\sim 5$ \\
\hline 91 & $\mathrm{SiC}(79)-\mathrm{Si}_{3} \mathrm{~N}_{4}(18.5)$ & Sintered & $\sim 100$ & 64 & 64 \\
\hline 93 & $\mathrm{SiC}(73)-\mathrm{Al}_{2} \mathrm{O}_{3}(14)-\mathrm{SiO}_{2}(11)$ & Sintered & $\sim 100$ & 64 & 64 \\
\hline 17 & $\mathrm{Al}_{2} \mathrm{O}_{3}(85)-\mathrm{SiO}_{2}(9)-\mathrm{P}_{2} \mathrm{O}_{5}(4)$ & Chemical & 40.3 & 76 & 64 \\
\hline 28 & $\mathrm{Al}_{2} \mathrm{O}_{3}(93)-\mathrm{P}_{2} \mathrm{O}_{5}(1)$ & Chemical & 20.5 & 64 & 33 \\
\hline 27 & $\mathrm{Al}_{2} \mathrm{O}_{3}(81)-\mathrm{Cr}_{2} \mathrm{O}_{3}(10)-\mathrm{P}_{2} \mathrm{O}_{5}(7)$ & Chemical & 5.9 & 43 & 18 \\
\hline 202 & $\mathrm{Al}_{2} \mathrm{O}_{3}$ (Winnofos Bond) & Chemical & 45.5 & 76 & 56 \\
\hline 2 & $\mathrm{Al}_{2} \mathrm{O}_{3}(99)-\mathrm{Na}_{2} \mathrm{O}(0.5)$ & Fused-cast & 7.2 & 20 & 19 \\
\hline 4 & $\mathrm{Al}_{2} \mathrm{O}_{3}(99)-\mathrm{B}_{2} \mathrm{O}_{3}(0.5)$ & Fused-cast & 8.3 & 24 & 22 \\
\hline 22 & $\mathrm{Cr}_{2} \mathrm{O}_{3}(80)-\mathrm{MgO}(8)-\mathrm{Fe}_{2} \mathrm{O}_{3}(6)$ & Fused-cast & $\sim 0$ & $\sim 0$ & $\sim 0$ \\
\hline 24 & $\mathrm{Al}_{2} \mathrm{O}_{3}(80)$ & Fused-cast & 4.5 & $\sim 18$ & 17 \\
\hline
\end{tabular}

Measured from the original hot face. 
TABLE V. Slag Composition During Test Run 3

\begin{tabular}{|c|c|c|c|c|}
\hline \multirow[b]{2}{*}{ Component } & \multicolumn{4}{|c|}{ Exposure Time, $\mathrm{h}$} \\
\hline & 3 & 188 & 358 & 532 \\
\hline $\mathrm{SiO}_{2}$ & $29.96^{\mathrm{a}}$ & 26.40 & 24.46 & 22.90 \\
\hline $\mathrm{P}_{2} \mathrm{O}_{5}$ & 0.06 & 0.05 & 0.04 & 0.01 \\
\hline $\mathrm{Cr}_{2} \mathrm{O}_{3}$ & 0.47 & 0.31 & 0.20 & 0.41 \\
\hline $\mathrm{Al}_{2} \mathrm{O}_{3}$ & 13.00 & 27.70 & 32.90 & 34.40 \\
\hline $\mathrm{MgO}$ & 4.10 & 3.44 & 2.44 & 2.04 \\
\hline $\mathrm{TiO}_{2}$ & 0.38 & 0.33 & 0.40 & 0.37 \\
\hline $\mathrm{Fe}_{2} \mathrm{O}_{3}$ & 11.19 & 8.58 & 8.69 & 6.33 \\
\hline $\mathrm{CaO}$ & 35.30 & 31.70 & 27.20 & 28.55 \\
\hline $\mathrm{Na}_{2} \mathrm{O}$ & $1.0-5.0$ & $0.05-0.50$ & $0.05-0.50$ & $0.05-0.50$ \\
\hline $\mathrm{K}_{2} \mathrm{O}$ & $0.5-1.0$ & $0.05-0.50$ & $0.05-0.50$ & $0.05-0.50$ \\
\hline $\mathrm{SO}_{3}$ & 0.037 & 0.020 & 0.020 & 0.025 \\
\hline $\mathrm{V}_{2} \mathrm{O}_{5}$ & $<0.01$ & $<0.01$ & $<0.01$ & $<0.01$ \\
\hline Residue & 0.84 & 0.66 & 2.80 & 4.40 \\
\hline B/A Ratio ${ }^{b}$ & 1.25 & 0.79 & 0.67 & 0.65 \\
\hline
\end{tabular}

at \%.

${ }^{\mathrm{b}}$ As in Table I. 
TABLE VI. Relative Corrosion Resistance of Refractories Exposed to Slag Attack in Test Run 3

\begin{tabular}{|c|c|c|c|c|c|}
\hline Number & Composition & Bond & $\begin{array}{l}\text { Normalized } \\
\text { Material } \\
\text { Lost, } \\
\text { vol } \%\end{array}$ & $\begin{array}{c}\text { Maximum } \\
\text { Depth of } \\
\text { Penetration, } \\
\text { mm }\end{array}$ & $\begin{array}{l}\text { Maximum } \\
\text { Depth of } \\
\text { Removal, } \\
\quad \mathrm{mm}\end{array}$ \\
\hline 19 & $\begin{array}{c}\mathrm{MgO}(53)-\mathrm{Cr}_{2} \mathrm{O}_{3}(20)-\mathrm{Al}_{2} \mathrm{O}_{3}(17) \\
-\mathrm{Fe}_{2} \mathrm{O}_{3}(8)\end{array}$ & Sintered & 3.2 & 35.6 & 11.4 \\
\hline 20 & $\begin{aligned} \mathrm{MgO}(59) & -\mathrm{Cr}_{2} \mathrm{O}_{3}(19)-\mathrm{Al}_{2} \mathrm{O}_{3}(13) \\
& -\mathrm{Fe}_{2} \mathrm{O}_{3}(7)\end{aligned}$ & Sintered & 1.5 & 38.1 & 8.1 \\
\hline 21 & $\begin{array}{c}\mathrm{MgO}(64)-\mathrm{Cr}_{2} \mathrm{O}_{3}(15)-\mathrm{Al}_{2} \mathrm{O}_{3}(13) \\
-\mathrm{Fe}_{2} \mathrm{O}_{3}(6)\end{array}$ & Sintered & 2.3 & 40.6 & 11.4 \\
\hline 29 & $\begin{array}{c}\mathrm{MgO}(63)-\mathrm{Cr}_{2} \mathrm{O}_{3}(18)-\mathrm{Al}_{2} \mathrm{O}_{3}(5) \\
-\mathrm{Fe}_{2} \mathrm{O}_{3}(12)\end{array}$ & Sintered & 1.4 & 38.1 & 5.8 \\
\hline 30 & $\begin{array}{c}\mathrm{MgO}(63)-\mathrm{Cr}_{2} \mathrm{O}_{3}(17)-\mathrm{Al}_{2} \mathrm{O}_{3}(10) \\
-\mathrm{Fe}_{2} \mathrm{O}_{3}(9)\end{array}$ & Sintered & 1.5 & 40.6 & 8.9 \\
\hline 23 & $\mathrm{Al}_{2} \mathrm{O}_{3}(90)-\mathrm{Cr}_{2} \mathrm{O}_{3}(10)$ & Sintered & 5.8 & 48.3 & 10.7 \\
\hline 852 & $\mathrm{Al}_{2} \mathrm{O}_{3}(81)-\mathrm{Cr}_{2} \mathrm{O}_{3}(17)$ & Sintered & 2.7 & 27.9 & 14.5 \\
\hline 26 & $\mathrm{Al}_{2} \mathrm{O}_{3}(68)-\mathrm{Cr}_{2} \mathrm{O}_{3}(32)$ & Sintered & 2.8 & 58.4 & 16.0 \\
\hline 36 & $\mathrm{Si}_{2} \mathrm{ON}_{2}(70)-\mathrm{Si}_{3} \mathrm{~N}_{4}(20)-\mathrm{SiC}(10)$ & Sintered & 45.5 & $62.7^{\mathrm{a}}$ & $62.7^{a}$ \\
\hline 14 & $\mathrm{Al}_{2} \mathrm{O}_{3}(92)-\mathrm{SiO}_{2}(8)$ & Sintered & 10.3 & 45.7 & 35.6 \\
\hline 34 & $\mathrm{Al}_{2} \mathrm{O}_{3}(56)-\mathrm{SiO}_{2}(27)-\mathrm{ZrO}_{2}(16)$ & Sintered & 59.0 & $73.7^{\mathrm{a}}$ & $73.7^{\mathrm{a}}$ \\
\hline 33 & $\mathrm{MgO}, \mathrm{Al}_{2} \mathrm{O}_{3}$ & Sintered & 7.0 & $73.7^{\mathrm{a}}$ & 22.9 \\
\hline 18 & $\mathrm{Al}_{2} \mathrm{O}_{3}(2 \mathrm{I})-\mathrm{Cr}_{2} \mathrm{O}_{3}(40)-\mathrm{Fe}_{2} \mathrm{O}_{3}(23)$ & Chemical & 5.8 & 53.3 & 11.4 \\
\hline 24 & $\mathrm{Al}_{2} \mathrm{O}_{3}(98)$ & Fused-cast & 4.0 & 22.9 & 19.6 \\
\hline 22 & $\mathrm{Cr}_{2} \mathrm{O}_{3}(80)-\mathrm{MgO}(8)-\mathrm{Fe}_{2} \mathrm{O}_{3}(6)$ & Fused-cast & 0.3 & 5.1 & 1.9 \\
\hline 65 & $\mathrm{Al}_{2} \mathrm{O}_{3}(50)-\mathrm{ZrO}_{2}(34)-\mathrm{SiO}_{2}(14)$ & Fused-cast & 33.4 & $73.7^{a}$ & $73.7^{a}$ \\
\hline
\end{tabular}

${ }^{\text {a }}$ Complete attack.

$\mathrm{b}_{\text {Measured from the original hot face. }}$ 


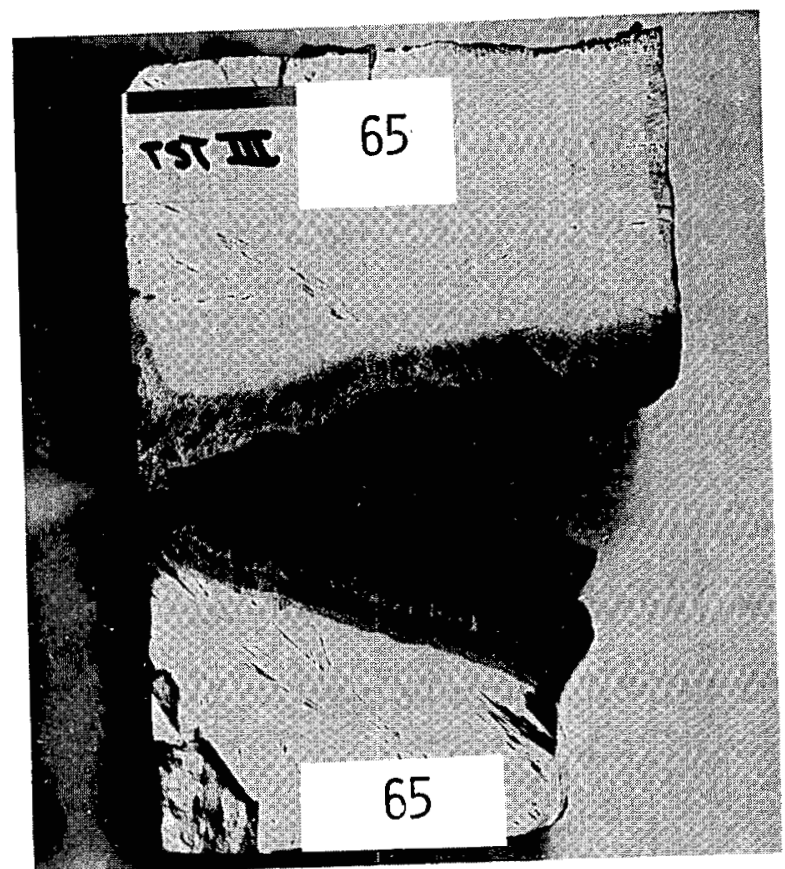

(a)

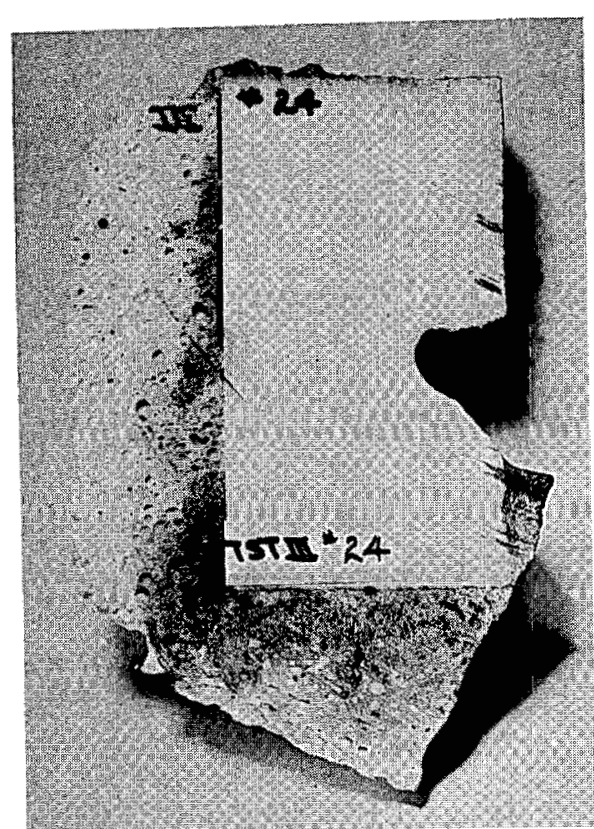

(b)

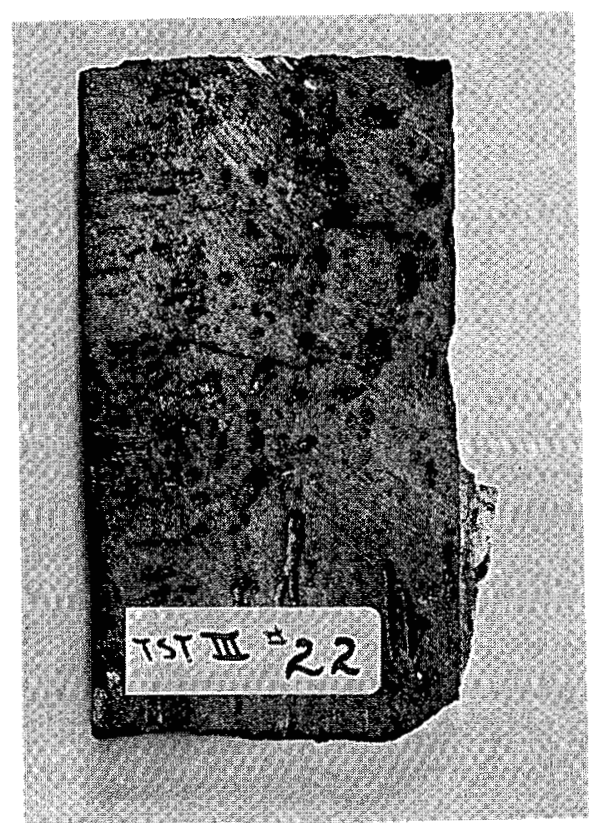

(c)

Fig. 2. Cut Sections of the Fused-cast Refractories Exposed to Slag Attack in Test Run 3. (a) Alumina-zirconia-silica (number 65), (b) alumina (number 24), and (c) $\mathrm{Cr}_{2} \mathrm{O}_{3}-\mathrm{MgO}-\mathrm{Fe}_{2} \mathrm{O}_{3}$ spinel (number 22; note negligible attack). Neg. No. MSD-63801. 
B. Corrosion Tests With Water Cooling

The slag-corrosion furnace was modified to produce prototypic thermal gradients within the refractory bricks through the use of water-cooled chills (Fig. 3). Water temperature and flow were monitored so that heat flux could be calculated. Standard 9-in. x 4-1/2-in. x $(3,2)-i n$. wedge bricks were used (if wedges were not available, straights were cut to fit) with the narrow ends of the bricks exposed to the slag. The wedges were cut to three different lengths so that three different temperature gradients could be studied. Bricks of four different compositions were tested simultaneously. Each chill cooled three bricks of the same length and composition. The center brick was thereby shielded from the effects of neighboring bricks of different lengths and/or composition.

The fourth test run included silicon carbide refractories with three different bond systems: nitride (number 91), silicate (number 93), and oxynitride (number 37). A silicon oxynitride composition (number 36) was also included. Thermocouples were inserted in the center brick in each group of three at $12.7 \mathrm{~mm}(0.5 \mathrm{in.}), 38.1 \mathrm{~mm}$ (1.5 in.), $88.9 \mathrm{~mm}$ (3.5 in.), and (for full-length bricks) $177.8 \mathrm{~mm}$ ( 7 in.) from the hot face. To enhance heat transfer between the chills and bricks, a high thermal conductivity silicon carbide cement* mixed with a monoaluminum phosphate solution ${ }^{\dagger}$ was utilized.

The slag used in test run 4 was a simulated Montana Rosebud (Table VII). Slag was introduced three times during the test (at 0,50 , and $160 \mathrm{~h}$ ). The initially high iron oxide content resulted from a batching error that was rectified at $160 \mathrm{~h}$. In the determination of the ferritic content, the weight percent of $\mathrm{Fe}_{2} \mathrm{O}_{3}$ was obtained by subtracting the weight percent $\mathrm{Fe}^{++}$from the total Fe content. The ferritic content at $500 \mathrm{~h}$ was $\sim 15 \%$, which indicated a reducing atmosphere. Posttest examination of the slag bath revealed two layers that were quite different in appearance. A dark greenish-black glassy slag, with a composition essentially identical to that of the sample taken from the hot furnace just prior to shutdown, rested upon a grayish slag with a crystalline, rocky appearance. Posttest chemical analysis of the frozen slag showed that the rocky slag was somewhat lower in $\mathrm{SiO}_{2}$ and somewhat higher in $\mathrm{Fe}_{2} \mathrm{O}_{3}$ than the glassy slag. Probing during slag sampling indicated that the rocky slag crystallized slowly during the test and, therefore, did not contribute to the attack on the brick.

The furnace plenum temperature and the temperatures in the $3 / 4-1$ ength bricks at a midheight location, $12.7 \mathrm{~mm}(0.5 \mathrm{in.})$ from the hot faces, are shown in Fig. 4. The slag-refractory interfacial temperature was $\sim 1450^{\circ} \mathrm{C}$ for the full-length bricks, as determined with an optical pyrometer. The thermal profile that existed within the bricks after the slag was added on April 21 is shown in Fig. 5. Note that since the slag covered only part of the hot face of the brick, the heat flow through the brick was not uniform; this made determination of the hot-face temperature difficult. Oxygen partial pressure was maintained at $\sim 10^{-3} \mathrm{~Pa}$.

*Carborundum Company, Keasbey, NJ.

${ }^{\dagger}$ Mobil Chemical Company, Richmond, VA. 


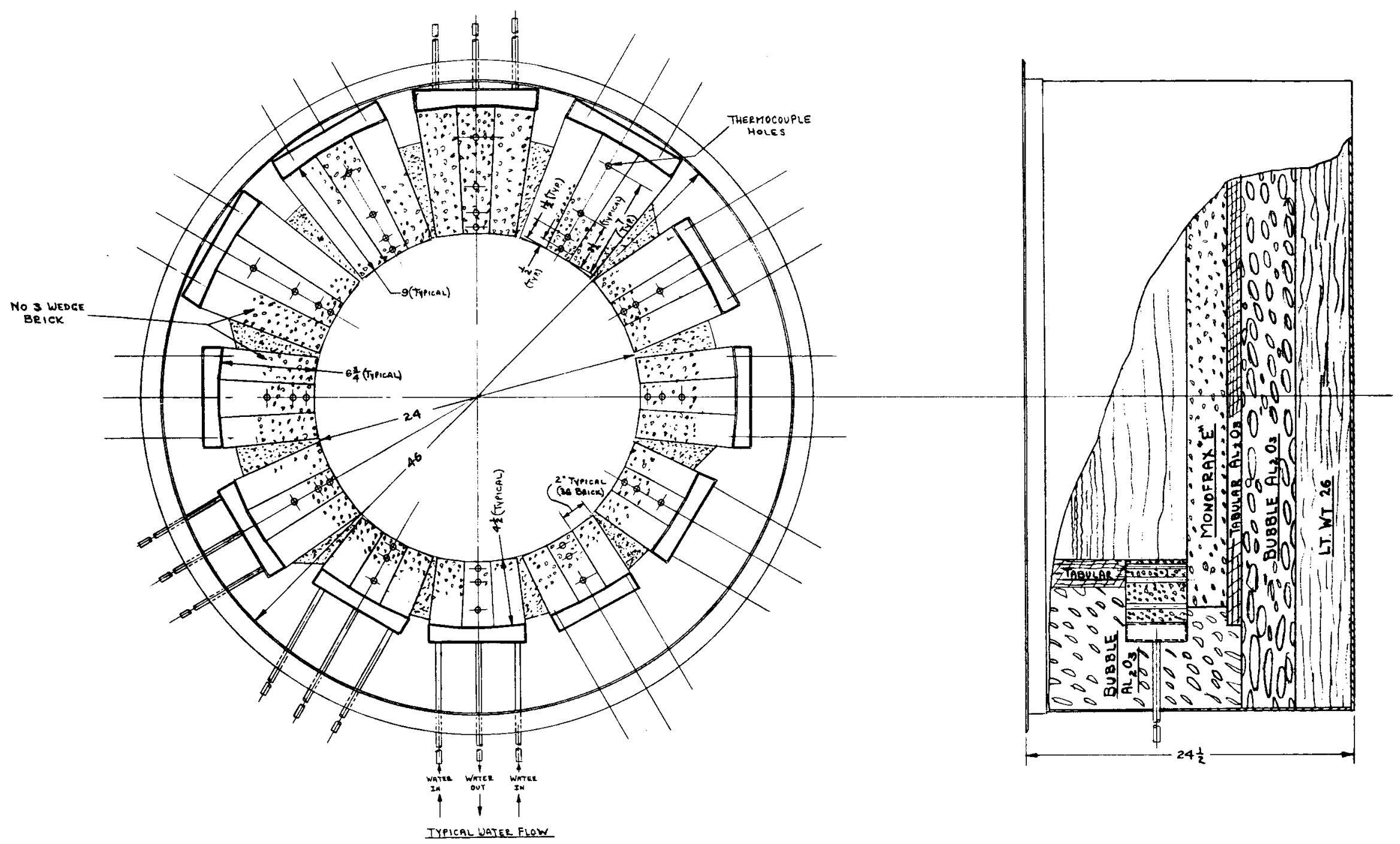

Fig. 3. Top and Side Views of the New Bottom Section of the Slag-corrosion Furnace. Dimensions are in inches. ANL Neg. No. 306-77-47. 
TABLE VII. Slag Composition During Test Run 4

\begin{tabular}{|c|c|c|c|c|c|c|}
\hline \multirow{2}{*}{\multicolumn{2}{|c|}{ Component }} & \multicolumn{3}{|c|}{ Exposure Time, h } & \multirow[b]{2}{*}{ Glassy Slag } & \multirow[b]{2}{*}{ Rocky Slag } \\
\hline & & 3 & 184 & 500 & & \\
\hline $\mathrm{SiO}_{2}$ & $(S)$ & $35^{\mathrm{a}}$ & 41 & 41.6 & 42 & 35 \\
\hline $\mathrm{Al}_{2} \mathrm{O}_{3}$ & (A) & 14 & 20 & 21 & 21.1 & 20.9 \\
\hline $\mathrm{Fe}_{2} \mathrm{O}_{3}$ & $\left(F_{1}\right)$ & 4.7 & 0.4 & 1.3 & 1.4 & 6.5 \\
\hline $\mathrm{FeO}$ & $\left(F_{2}\right)$ & 16 & 5.9 & 6.4 & 6.9 & 8.6 \\
\hline $\mathrm{CaO}$ & (C) & 21.1 & 24.2 & 22 & 20.2 & 21 \\
\hline $\mathrm{MgO}$ & (M) & 6.2 & 4.5 & 5.5 & 6.2 & 5.2 \\
\hline $\mathrm{Na}_{2} \mathrm{O}$ & $(\mathrm{N})$ & 1.2 & 1.8 & 0.6 & 0.6 & 1.2 \\
\hline $\mathrm{K}_{2} \mathrm{O}$ & (K) & 1.1 & 1.1 & 0.6 & 0.6 & 0.7 \\
\hline $\mathrm{TiO}_{2}$ & $(\mathrm{~T})$ & 0.7 & 1.1 & 1.0 & 1.0 & 0.9 \\
\hline \multicolumn{2}{|c|}{ B/A Ratio ${ }^{a}$} & 1.0 & 0.62 & 0.59 & 0.57 & 0.78 \\
\hline $\begin{array}{l}\text { Ferrit } \\
\text { Conten }\end{array}$ & , c \% & 21 & 6 & 15 & Ferritic & 40 \\
\hline
\end{tabular}

Wt $\%$.

$\mathrm{b}_{\mathrm{B} / \mathrm{A}}=\left(\mathrm{F}_{1}+\mathrm{F}_{2}+\mathrm{C}+\mathrm{M}+\mathrm{N}+\mathrm{K}\right) /(\mathrm{S}+\mathrm{A}+\mathrm{T})$.

$\mathrm{c}_{\text {Ferritic content }}=\frac{\text { wt } \%\left(\mathrm{Fe}_{2} \mathrm{O}_{3}\right)}{\mathrm{wt} \%\left(\mathrm{Fe}_{2} \mathrm{O}_{3}\right)+1.11 \mathrm{wt} \%(\mathrm{Fe})+1.43 \mathrm{wt} \%(\mathrm{Fe})} \cdot$ 


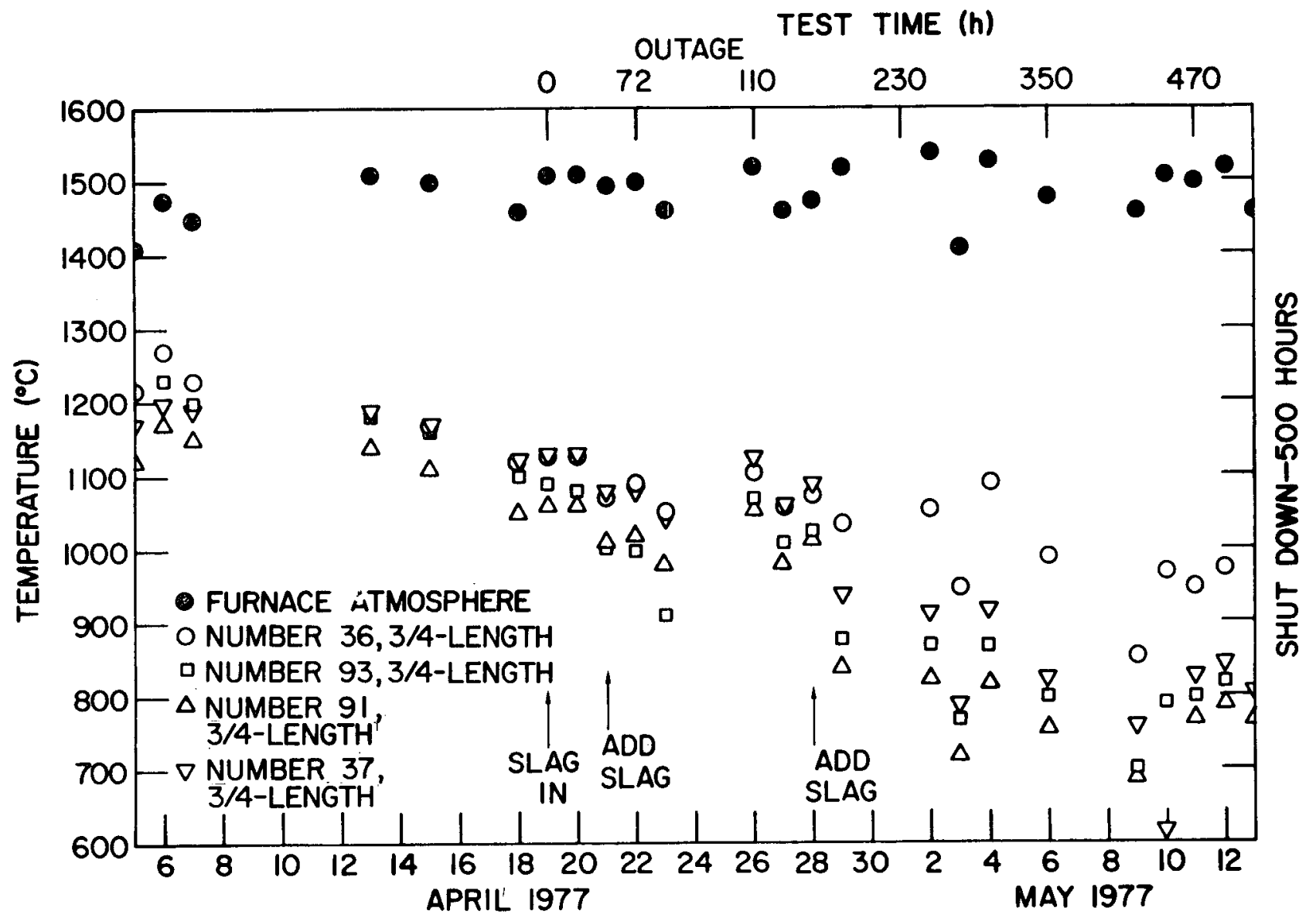

Fig. 4. Furnace Plenum Temperature and Midheight Brick Temperatures $12.7 \mathrm{~mm}$ (0.5 in.) from the Hot Face of 3/4-length Bricks of Each Composition During Test Run 4. ANL Neg. No. 306-77-382. 
(a)

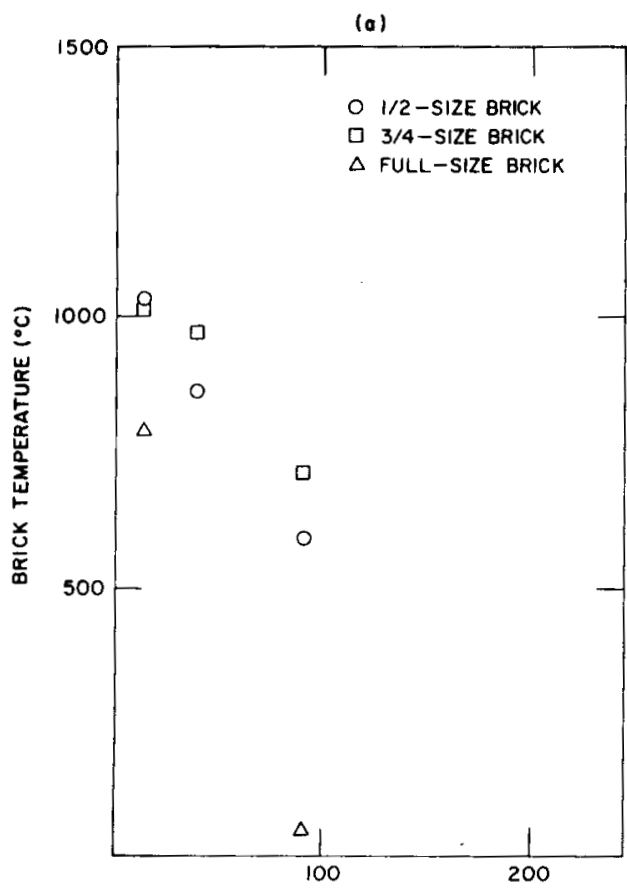

DISTANCE FROM HOT FACE (mm)

(c)

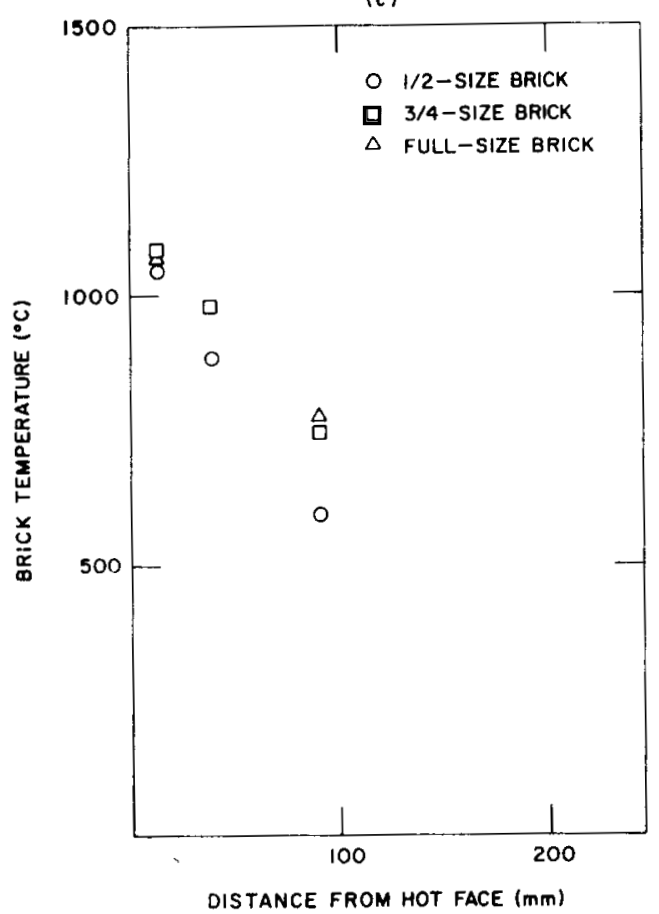

(b)

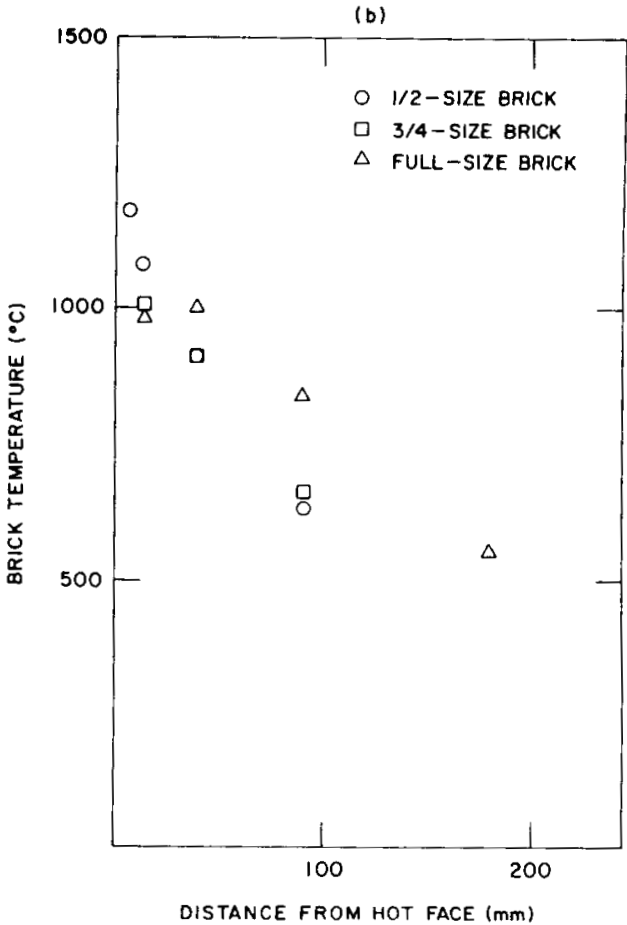

(d)

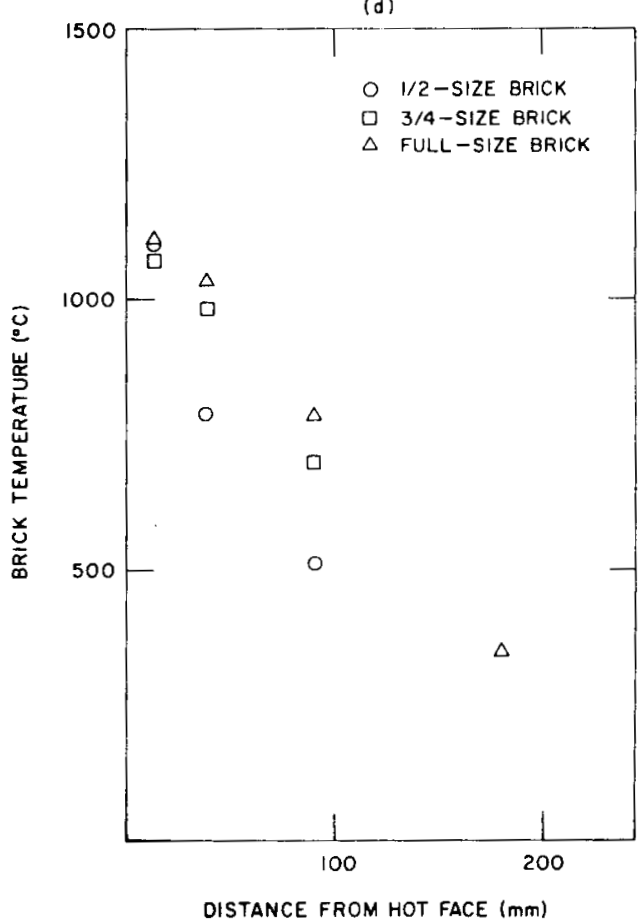

Fig. 5. Midheight Temperatures in Bricks During Test Run 4 at Four Locations in Fu11-1ength Bricks and at Three Locations in 3/4- and 1/2-1ength Bricks. (a) Nitride-bonded silicon carbide (number 91), (b) silicate-bonded silicon carbide (number 93), (c) oxynitride-bonded silicon carbide (number 37), and (d) silicon oxynitride (number 36). Missing data points indicate thermocouple failures. ANL Neg. No. 306-77-386. 
The bricks were removed from the furnace after $500 \mathrm{~h}$. They were sectioned lengthwise in the vertical plane so that slag attack (material removal and slag penetration) could be viewed in cross section. The vertical sections cut from the 3/4-1ength bricks of each type are shown (right side up) in Fig. 6. The vertical face of each brick opposite the ruler was exposed to slag. Three lines of attack are visible that correspond to the three levels of slag during the test. Although these three lines are apparent on a11 bricks, in the photographs they are most evident on the silicon oxynitride, the material that was attacked the most.

The relative resistance of the four refractory compositions to slag attack in test run 4 is summarized in Table VIII. The first attack line (designated "bottom" in Table VIII) corresponds to an $\sim 50-h$ exposure to slag with a B/A ratio of 1.0 . The second attack line corresponds to an $\sim 110-\mathrm{h}$ exposure to slag of similar composition. The third attack line resulted from a 340-h exposure to slag with a B/A ratio of $\sim 0.6$. Since the vertical temperature gradient in the slag is large, little attack occurs below the slag line. For each position, Table VIII indicates the maximum depth to which the refractory was actually removed.

All of the silicon carbide bricks exhibited little attack, contrary to the results obtained in test run 2 in which water cooling was not employed. The capability of the silicon carbide to resist attack may be attributed to the high thermal flux within the bricks, which reduced the hot-face temperature to $\sim 1450^{\circ} \mathrm{C}$. Typical values of heat flux for the silicon carbide bricks with chills were $40-50 \mathrm{~kW} / \mathrm{m}^{2}$ for full-length bricks; $50-70 \mathrm{~kW} / \mathrm{m}^{2}$ for $3 / 4-$ length bricks; and $60-90 \mathrm{~kW} / \mathrm{m}^{2}$ for $1 / 2-1$ ength bricks. The heat flux values were obtained by multiplying the measured thermal gradient by the published value of thermal conductivity, and should be considered only approximate because of the nonuniform heat-flow conditions mentioned previously.

Only slight differences in resistance to slag attack among the three types of silicon carbide bricks were detected. The oxynitride-bonded silicon carbide brick (number 37) was somewhat less resistant; the silicon oxynitride brick (number 36) was much less resistant, with the maximum depth of removal an order of magnitude higher than in any of the carbide bricks. The effect of the length of the brick on the depth of removal is shown in Fig. 7, and, as can be seen, even the 1/2-size silicon oxynitride brick exhibited substantial attack. 


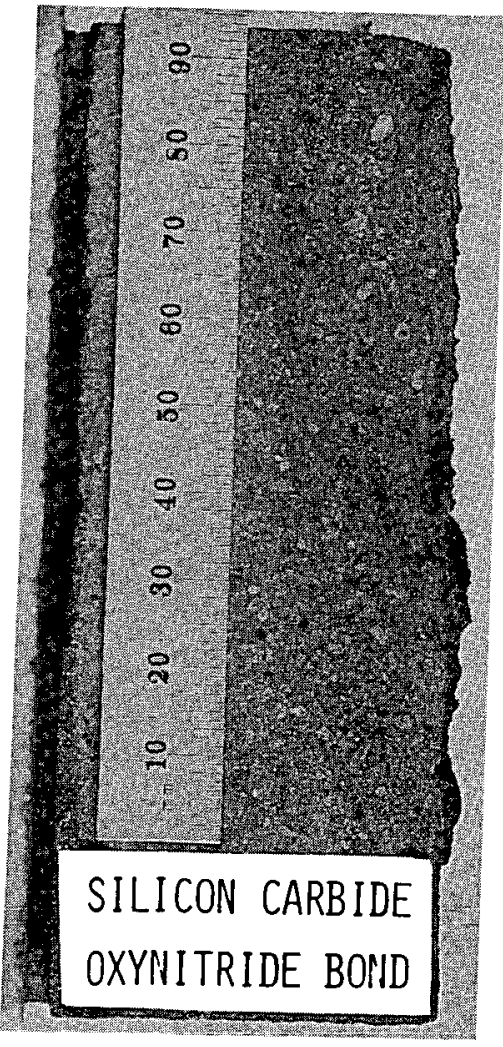

(a)

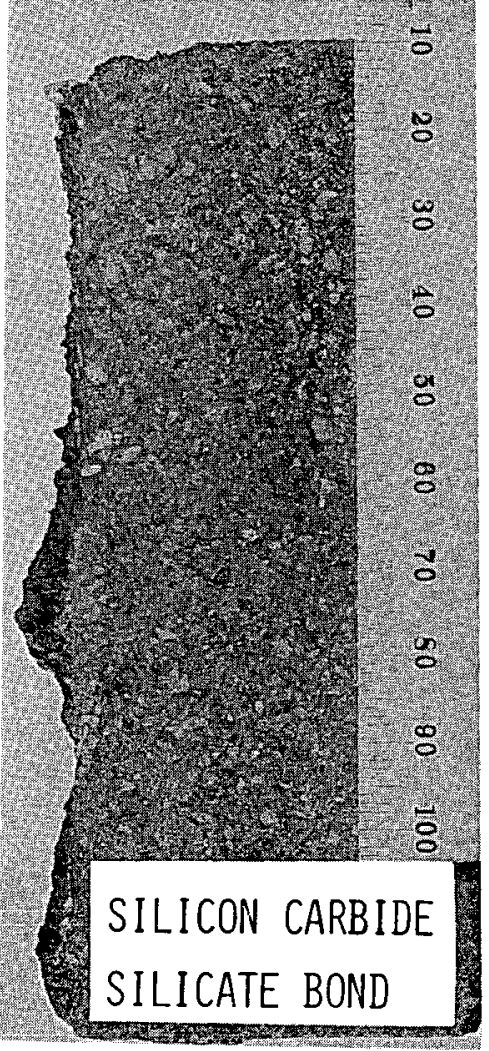

(b)

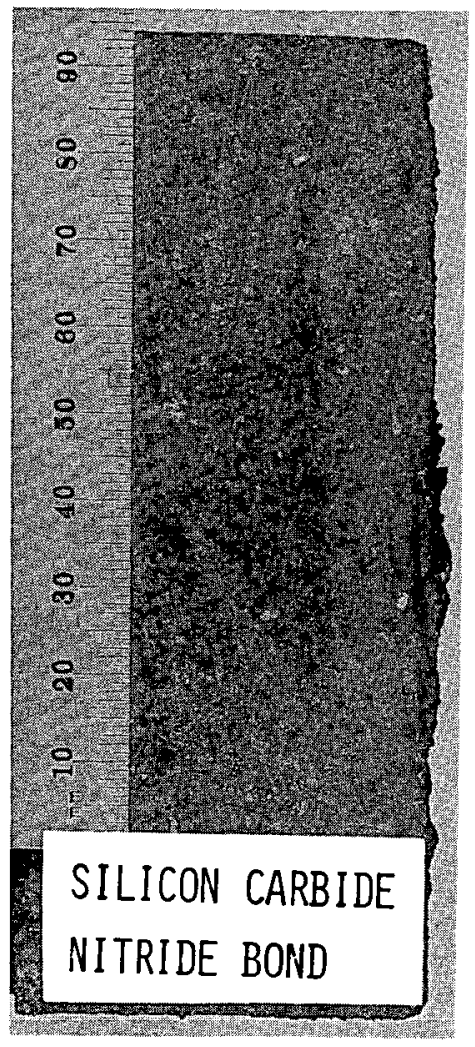

(c)

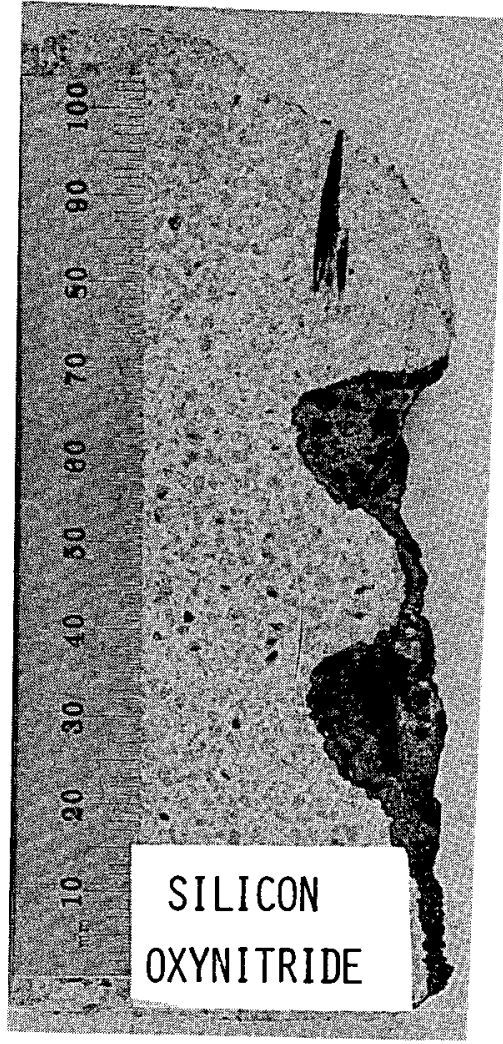

(d)

Fig. 6. Cut Sections of the 3/4-1ength Refractories Exposed to Slag Attack in Test Run 4 . The vertical faces opposite the ruler were exposed to the slag. (a) 0xynitride-bonded silicon carbide (number 37),

(b) silicate-bonded silicon carbide (number 93), (c) nitride-bonded silicon carbide (number 91), and (d) silicon oxynitride (number 36). Note the three levels of slag attack. ANL Neg. No. 306-77-387. 
TABLE VIII. Relative Corrosion Resistance of Refractories Exposed to Slag Attack in Test Run 4

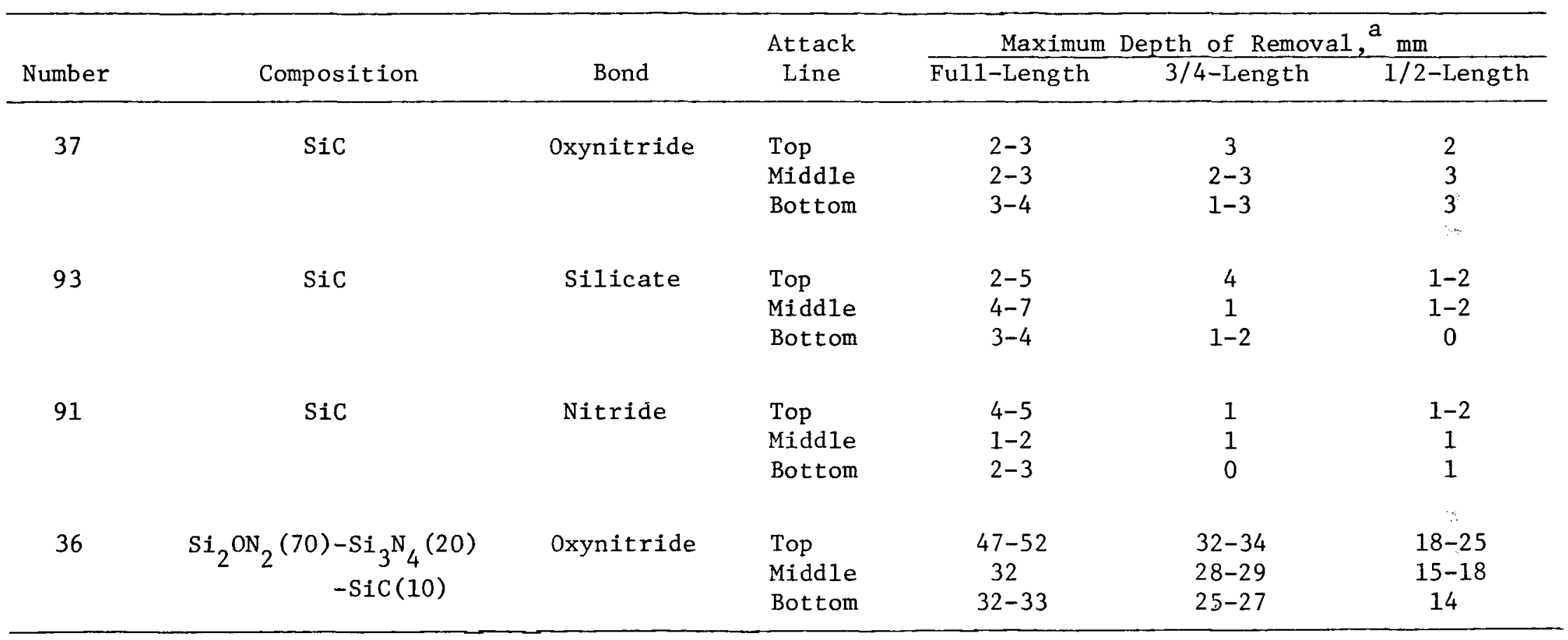

Measured from the original hot face. 


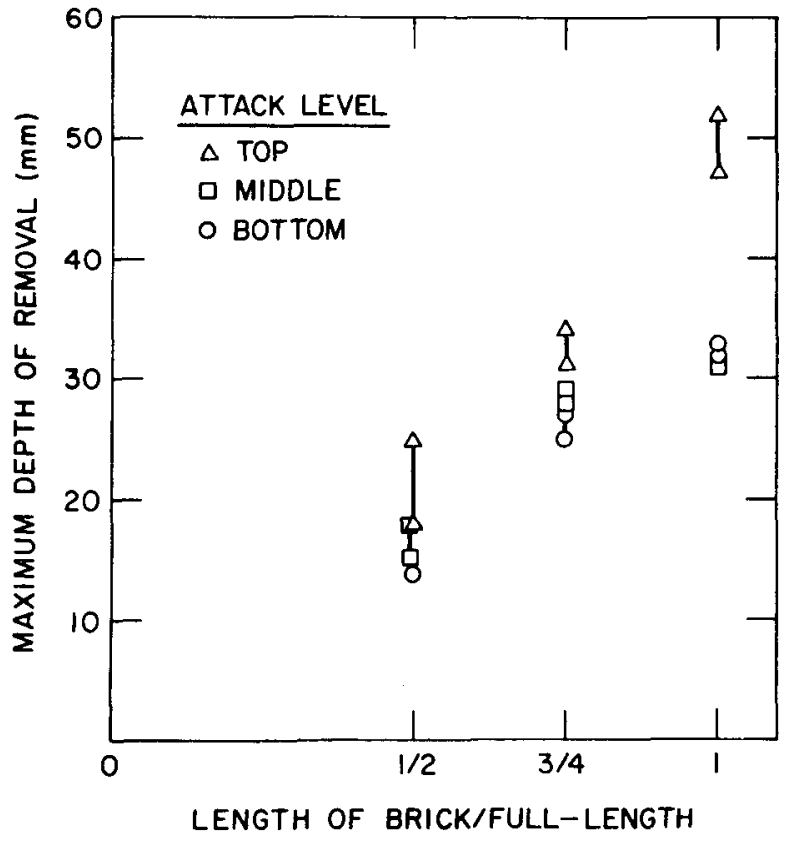

Fig. 7. Maximum Depth of Removal as a Function of Brick Length for Silicon Oxynitride Refractory Bricks Exposed in Test Run 4. ANL Neg. No. 306-77-372.
The fifth run included four direct-bonded magnesia-chrome spinel bricks. The furnace temperatures, and midheight temperatures in the 3/4-1ength bricks at a location $38.1 \mathrm{~mm}$ from the hot face, are shown in Fig. 8. Shown for comparison are the temperatures within a 3/4-length silicon carbide brick (number 93) from run 4, also at a location $38.1 \mathrm{~mm}$ from the hot face. Typical thermal profiles within the bricks are shown in Fig. 9. Since the thermal conductivity of silicon carbide refractories is almost an order of magnitude higher than that of the magnesiachrome refractories, some differences in the thermal profiles were observed (compare Fig. 9 with Fig. 5). Typical heat fluxes in the magnesia-chrome bricks were $8 \mathrm{~kW} / \mathrm{m}^{2}$ for full-length bricks, $11 \mathrm{~kW} / \mathrm{m}^{2}$ for $3 / 4-1$ ength bricks, and $13 \mathrm{~kW} / \mathrm{m}^{2}$ for $1 / 2-1$ ength bricks. These values are $1 / 5$ to $1 / 7$ of the heat-flux values in the silicon carbide bricks.

The composition of the slag during test run 5 is summarized in Table IX. The $B / A$ ratio was $\sim 0.7$ and the ferritic content was negligible. The partial pressure of oxygen was $\sim 10^{-3}$ to $10^{-4} \mathrm{~Pa}$. Two charges of synthetic slag were made. A glassy-rocky slag separation similar to that which occurred in run 4 was observed during posttest examination. Two slag-attack lines, corresponding to the two slag-bath levels but not to the slag-separation level, was noted.

The relative corrosion resistance of the magnesia-chrome refractories tested in run 5 is summarized in Table $X$. Posttest photographs of partial sections of the full-length bricks are shown in Fig. 10. For each brick, the vertical side opposite the ruler was exposed to the slag and two lines of slag attack are evident, corresponding to the two additions of slag made during the test. The B/A ratio of the slag (a simulated Montana Rosebud) was constant at $\sim 0.6$ throughout the entire test, but an excursion of the plenum temperature to $\sim 1600^{\circ} \mathrm{C}$ occurred just before the second slag addition. Thus, the bottom line of slag attack corresponds to an $\sim 70-\mathrm{h}$ exposure at a plenum temperature of 1500 to $1600^{\circ} \mathrm{C}$, whereas the top line of attack was the result of an $\sim 430-\mathrm{h}$ exposure at a plenum temperature of $1500^{\circ} \mathrm{C}$. 


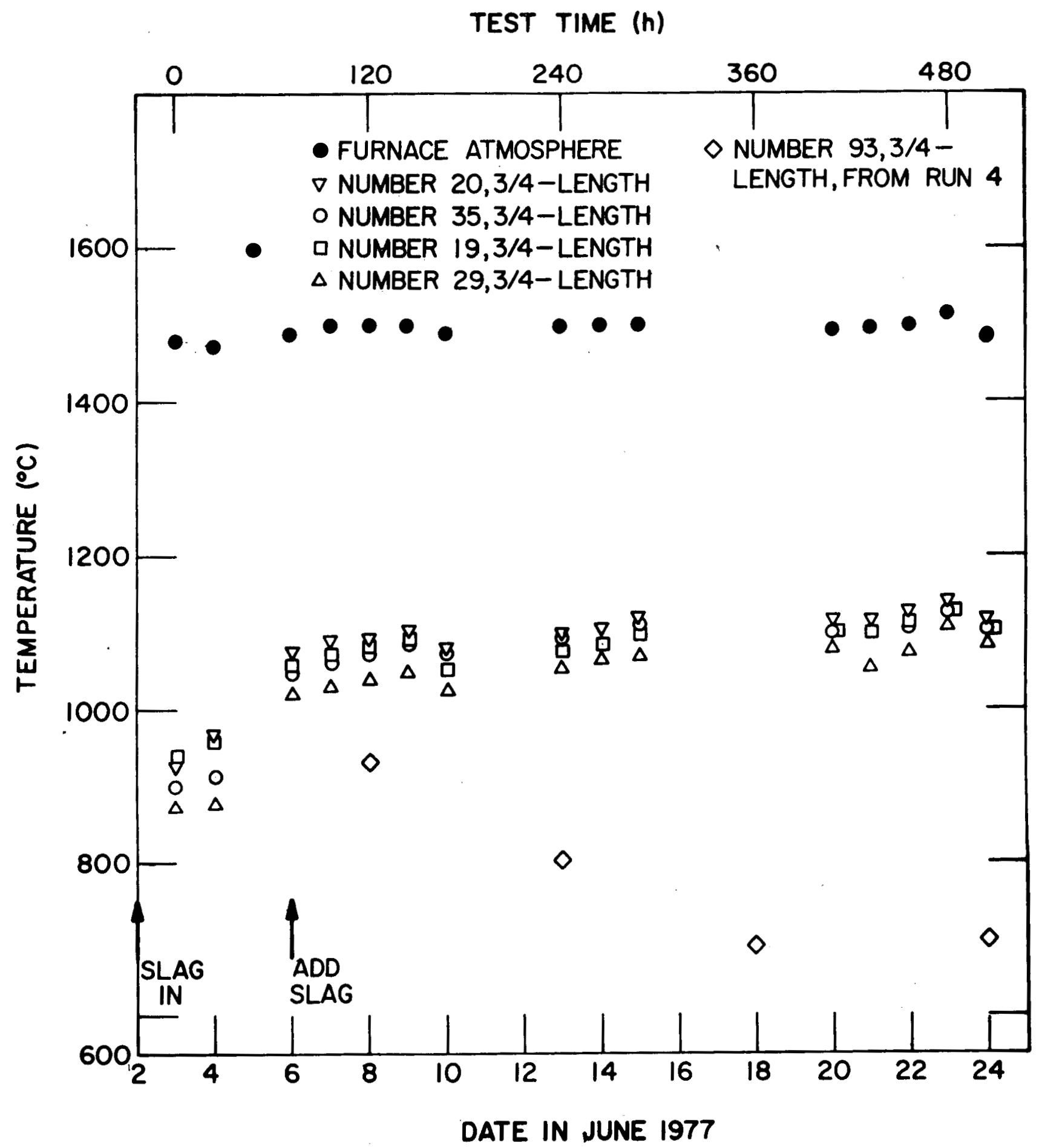

Fig. 8. Furnace Plenum Temperature and Midheight Brick Temperatures $38.1 \mathrm{~mm}$ (1.5 in.) from the Hot Face of Magnesia-Chrome 3/4-length Refractory Bricks During Test Run 5. ANL Neg. No. 306-77-381. 


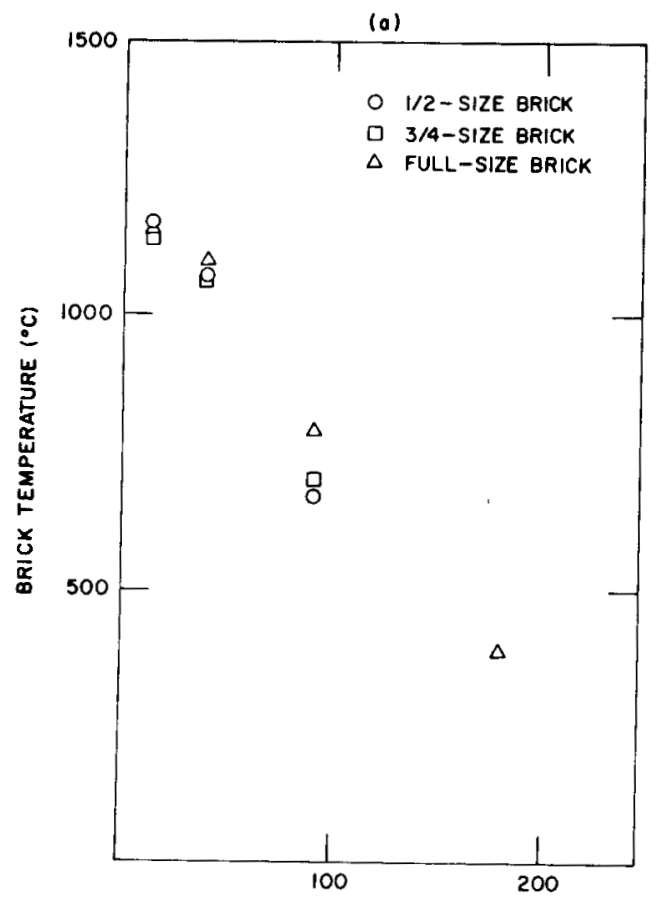

DISTANCE FROM HOT FACE (mm)

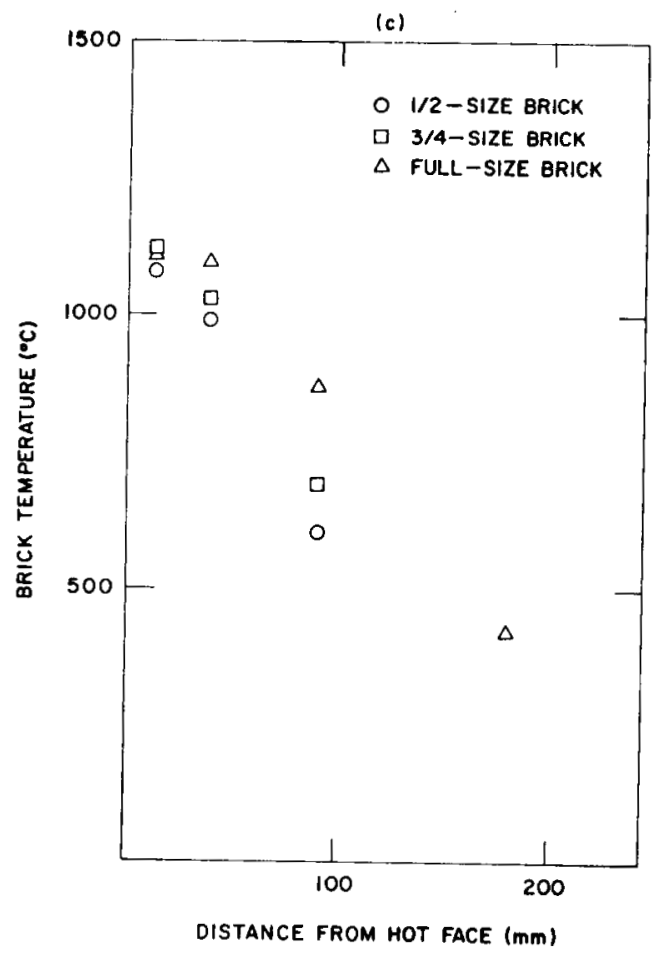

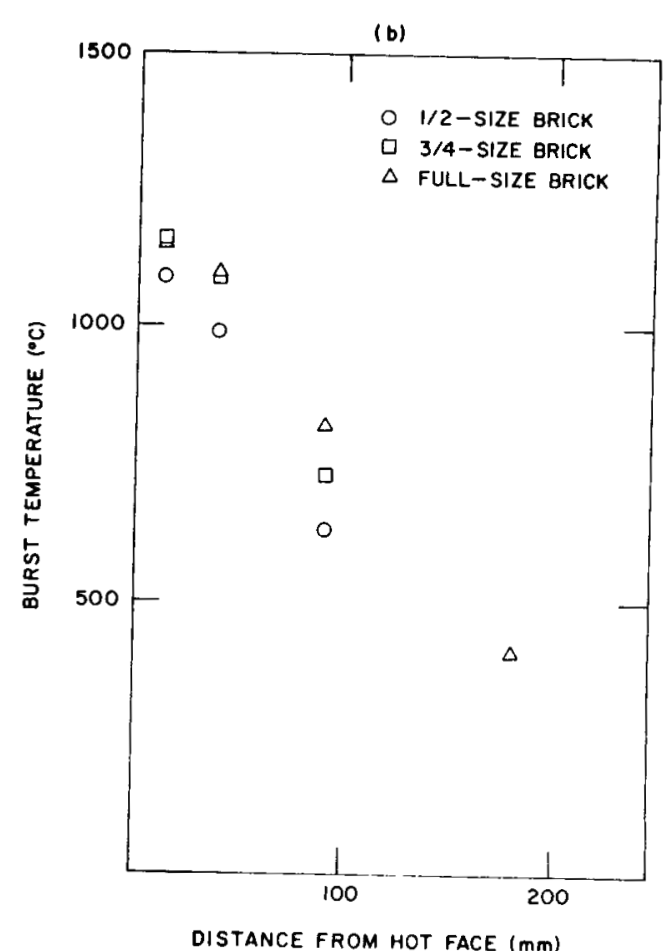

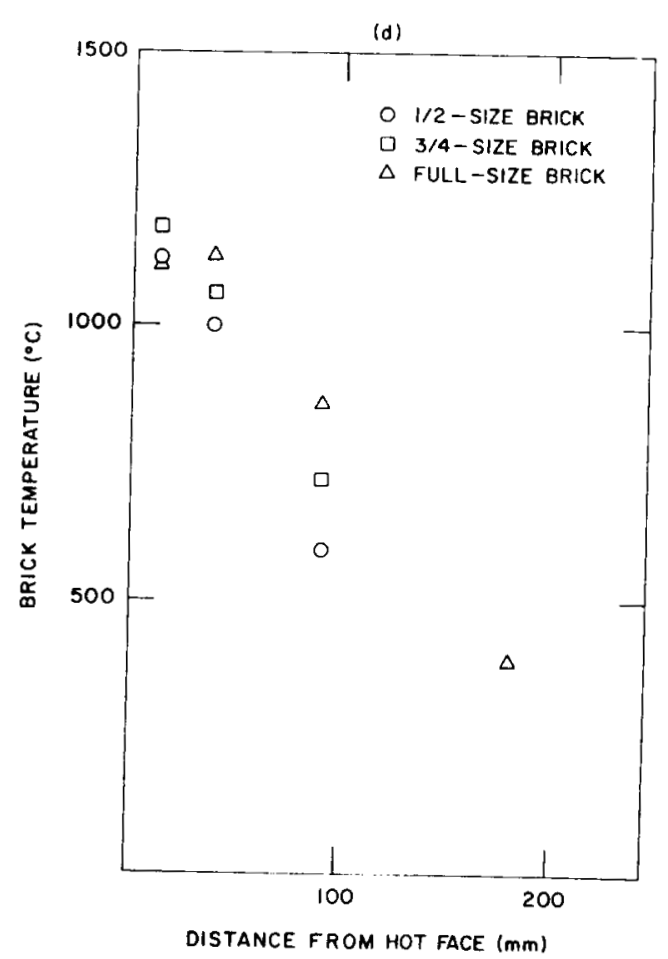

Fig. 9. Midheight Temperatures in Direct-bonded Magnesia-Chrome Bricks During Test Run 5 at Four Locations in Full-length Bricks and at Three Locations in 3/4- and 1/2-length Bricks. (a) Number 19, (b) number 20, (c) number 29 , and (d) number 35. ANL Neg. No. 306-77-385. 
TABLE IX. Slag Composition During Test Run 5

\begin{tabular}{|c|c|c|c|c|c|c|c|}
\hline \multirow[b]{2}{*}{ Component } & \multicolumn{7}{|c|}{ Exposure Time, $h$} \\
\hline & 68 & (Near & $\begin{array}{c}163 \\
\text { Brick }\end{array}$ & Face) & $\begin{array}{l}163 \\
\text { (Near Center) }\end{array}$ & 331 & 499 \\
\hline $\mathrm{SiO}_{2}$ & $38^{a}$ & & 39.4 & & 39.1 & 40.5 & 40.7 \\
\hline $\mathrm{Al}_{2} \mathrm{O}_{3}$ & 22 & & 19 & & 18.6 & 20.4 & 20.1 \\
\hline $\mathrm{Fe}_{2} \mathrm{O}_{3}$ & 0.4 & & - & & - & - & - \\
\hline $\mathrm{FeO}$ & 6.2 & & 6.9 & & 7.0 & 6.4 & 6.4 \\
\hline $\mathrm{CaO}$ & 22 & & 24 & & 25 & 24 & 24.9 \\
\hline $\mathrm{MgO}$ & 7.6 & & 6.6 & & 6.2 & 5.8 & 5.9 \\
\hline $\mathrm{Na}_{2} \mathrm{O}$ & 1.6 & & 1.7 & & 1.8 & 1.2 & 0.7 \\
\hline $\mathrm{K}_{2} \mathrm{O}$ & 0.7 & & 1.0 & & 1.1 & 0.7 & 0.3 \\
\hline $\mathrm{TiO}_{2}$ & 0.9 & & 0.9 & & 1.0 & 0.8 & 0.9 \\
\hline $\mathrm{Cr}_{2} \mathrm{O}_{3}$ & 0.6 & & 0.5 & & 0.2 & 0.2 & 0.1 \\
\hline B/A Ratio ${ }^{b}$ & 0.6 & & 0.7 & & 0.7 & 0.6 & 0.6 \\
\hline $\begin{array}{l}\text { Ferritic } \\
\text { Content, } b \%\end{array}$ & $<1$ & & - & & - & - & - \\
\hline
\end{tabular}

$a_{\text {Wt }} \%$

${ }^{\mathrm{b}}$ As in Table VII. 
TABLE X. Relative Corrosion Resistance of Refractories Exposed to Slag Attack in Test Run 5

\begin{tabular}{|c|c|c|c|c|c|c|c|c|c|c|c|}
\hline \multirow[b]{2}{*}{ Number } & \multirow[b]{2}{*}{ Composition } & \multirow[b]{2}{*}{$\begin{array}{l}\text { Attack } \\
\text { Line }\end{array}$} & \multicolumn{3}{|c|}{$\begin{array}{l}\text { Maximum Depth } \\
\text { of Removal, } \mathrm{mm}\end{array}$} & \multicolumn{3}{|c|}{$\begin{array}{l}\text { Depth of Obvious } \\
\text { Penetration, }{ }^{a} \text { mm }\end{array}$} & \multicolumn{3}{|c|}{$\begin{array}{c}\text { Depth of Microstructural } \\
\text { Alteration, }{ }^{a} \mathrm{~mm}\end{array}$} \\
\hline & & & $\begin{array}{l}\text { Full- } \\
\text { length }\end{array}$ & $\begin{array}{l}3 / 4- \\
\text { length }\end{array}$ & $\begin{array}{l}1 / 2- \\
\text { length }\end{array}$ & $\begin{array}{l}\text { Ful1- } \\
\text { length }\end{array}$ & $\begin{array}{l}3 / 4- \\
\text { length }\end{array}$ & $\begin{array}{l}1 / 2- \\
\text { length }\end{array}$ & $\begin{array}{l}\text { Full- } \\
\text { length }\end{array}$ & $\begin{array}{l}3 / 4- \\
\text { length }\end{array}$ & $\begin{array}{l}1 / 2- \\
\text { length }\end{array}$ \\
\hline \multirow[t]{2}{*}{19} & $\mathrm{MgO}(53)-\mathrm{Cr}_{2} \mathrm{O}_{3}(20)-\mathrm{Al}_{2} \mathrm{O}_{3}(17)-\mathrm{Fe}_{2} \mathrm{O}_{3}(8)$ & Top & 7 & 8 & 7 & 9 & 9 & 9 & 52 & 41 & 37 \\
\hline & $-\mathrm{SiO}_{2}(2)-\mathrm{CaO}(1)$ & Bottom & 7 & 7 & 8 & 9 & 11 & 11 & 47 & 35 & 33 \\
\hline \multirow[t]{2}{*}{20} & $\mathrm{MgO}(59)-\mathrm{Cr}_{2} \mathrm{O}_{3}(19)-\mathrm{Al}_{2} \mathrm{O}_{3}(13)-\mathrm{Fe}_{2} \mathrm{O}_{3}(7)$ & Top & 7 & 6 & 5 & 11 & 7 & 6 & 52 & 41 & 31 \\
\hline & $-\mathrm{SiO}_{2}(1.5)-\mathrm{CaO}(0.5)$ & Bottom & 8 & 6 & 4 & 10 & 8 & 9 & 43 & 36 & 31 \\
\hline \multirow[t]{2}{*}{29} & $\mathrm{MgO}(63)-\mathrm{Cr}_{2} \mathrm{O}_{3}(18)-\mathrm{AI}_{2} \mathrm{O}_{3}(5)-\mathrm{Fe}_{2} \mathrm{O}_{3}(12)$ & Top & 7 & 8 & 5 & 8 & 9 & 6 & 44 & 32 & 28 \\
\hline & $-\mathrm{SiO}_{2}(1)-\mathrm{CaO}(1)$ & Bottom & 6 & 7 & 6 & 7 & 9 & 6 & 36 & 28 & 26 \\
\hline \multirow[t]{2}{*}{35} & $\mathrm{MgO}(60)-\mathrm{Cr}_{2} \mathrm{O}_{3}(15.5)-\mathrm{Al}_{2} \mathrm{O}_{3}(15)$ & Top & 9 & 9 & 4 & 9 & 10 & 5 & 53 & 37 & 32 \\
\hline & $-\mathrm{Fe}_{2} \mathrm{O}_{3}(7)-\mathrm{SiO}_{2}(1.5)-\mathrm{CaO}(1)$ & Bottom & 16 & 17 & 9 & 20 & 21 & 14 & 53 & 39 & 32 \\
\hline
\end{tabular}

Measured from the original hot face. 


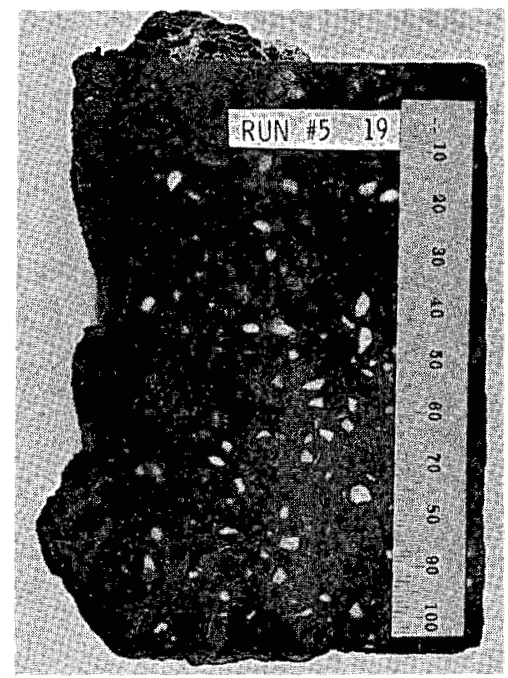

(a)

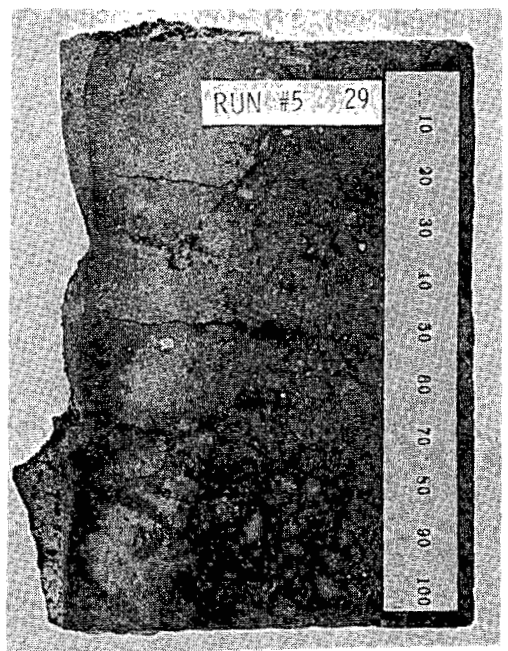

(c)

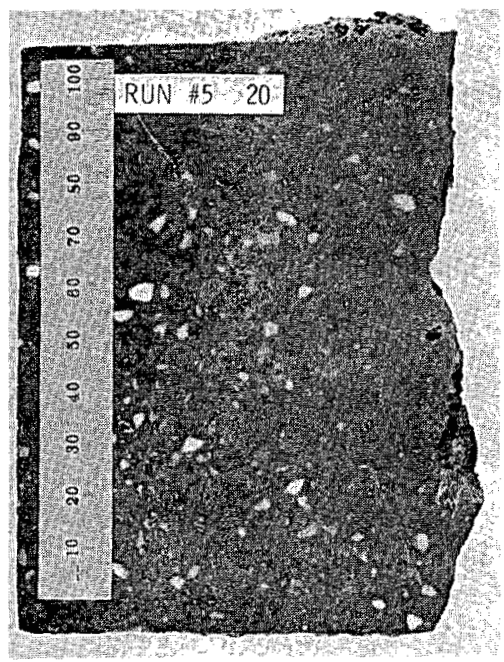

(b)

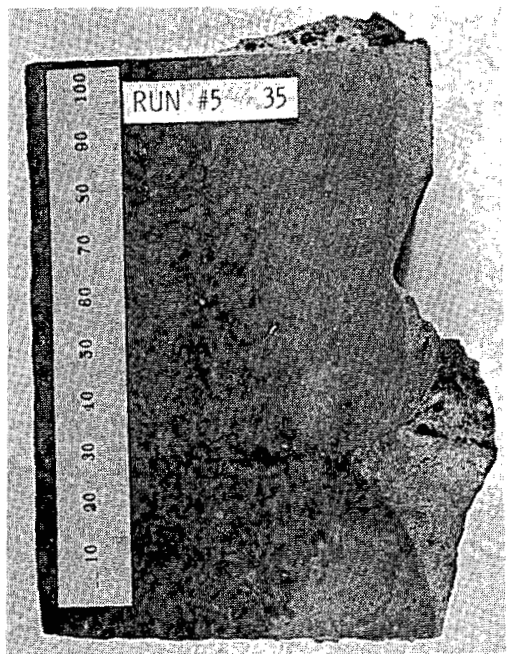

(d)

Fig. 10. Cut Sections of the Full-length Refractories Exposed to Slag Attack in Test Run 5. (a) Number 19, (b) number 20, (c) number 29, and (d) number 35. The vertical face opposite the ruler was exposed to the slag. There are two lines of attack, corresponding to the two levels of slag during the test. ANL Neg. No. 306-78-94. 
Bricks number 19, 20, and 29 exhibited similar resistance to corrosion, as measured by the depth of removal, whereas brick number 35 showed a marked sensitivity to the temperature excursion (Table $\mathrm{X}$ ). In addition to the bulk removal of the refractory material, a zone that was obviously penetrated by the slag and a zone in which the microstructure had been altered were evident (Fig. 10). Brick number 29 showed slightly greater resistance to penetration and alteration than the other three. Whereas the effect of length on the depth of removal and obvious penetration was small for numbers 19, 20, and 29 , the 1/2-length brick number 35 performed distinctly better than the fullor 3/4-length brick of the same composition. Also, the depth of alteration decreased as the length decreased for all bricks tested. In order to determine if the alterations in the microstructure were a result of penetration by slag, samples were core drilled and examined with the SEM using $x$-ray dispersive analysis. The relative intensities of the $\mathrm{Mg}, \mathrm{Al}, \mathrm{Si}, \mathrm{Cr}$, and $\mathrm{Fe}$ peaks were compared in the slag, slag-refractory interface, obviously penetrated refractory, and in the zone of microstructural alteration $\sim 40 \mathrm{~mm}$ from the hot face. Evidence for slag penetration was most clear-cut in brick number 35, somewhat less so in bricks number 19 and 20, and inconclusive in brick number 29 .

The sixth run was designed to evaluate the corrosion resistance of three fused-cast and one high-density sintered brick to the simulated Montana Rosebud slag (Table XI). The compositions of the bricks tested are listed in Table XII. Refractory number 2 is an electrically fused-cast alpha-alumina within a beta-alumina matrix. Refractory number 38 is an electrically fusedcast solid solution of alumina-chrome within a complex magnesia-chrome-alumina spinel matrix. Refractory number 39 is a fused-cast magnesia-chrome composition, whereas number 40 is of similar composition but is a direct-bonded, high-density brick.

The furnace plenum temperature and the midheight temperatures $38.1 \mathrm{~mm}$ ( 1.5 in.) from the hot face of the 3/4-length bricks are shown in Fig. 11 . At $305 \mathrm{~h}$ into the run, a temperature excursion, which occurred as a result of a thermocouple failure, caused the bubble-alumina insulating wall to slump; the test had to be terminated because of the resulting hot spot on the shell. It is estimated that the plenum temperature reached $\sim 1700$ to $1800^{\circ} \mathrm{C}$ overnight during the excursion. Temperature profiles in the bricks on August 18, 1977 are shown in Fig. 12. The relative resistance to corrosion of the refractories in run 6 is presented in Table XII, and cut sections of the 3/4-length bricks are shown in Fig. 13. Only one line of attack is evident upon examination despite the fact that slag was added twice during the test. The absence of two lines of attack indicates that the corrosion which occurred during the temperature excursion was sufficient to eradicate the first line of attack. A comparison of the attack on brick number 39 in this test with the attack on numbers 19 and 20 in test 5 (bricks of similar composition and structure) indicates that the conditions in run 6 were very severe indeed. In light of this severity, the corrosion resistance of the fused-cast alumina-chrome brick (number 38) may be quite good at $1450-1500^{\circ} \mathrm{C}$, and therefore it will be retested in the future. As evident from the posttest photographs, bricks number 2 and 39 contained substantial porosity which provided an easy avenue for penetration and corrosion. Also evident are numerous thermal-shock cracks that occurred in the three fused-cast refractories (numbers 2, 38, and 39). No such cracks were found in the sintered brick (number 40). 
TABLE XI. Slag Composition During Test Run 6

\begin{tabular}{|c|c|c|c|}
\hline \multirow[b]{2}{*}{ Component } & \multicolumn{3}{|c|}{ Exposure Time, $\mathrm{h}$} \\
\hline & 8 & 137 & 303 \\
\hline $\mathrm{SiO}_{2} \quad$ (S) & $40.6^{a}$ & 40.1 & 35.5 \\
\hline $\mathrm{Al}_{2} \mathrm{O}_{3}$ & 18.0 & 17.8 & 24.8 \\
\hline $\mathrm{Fe}_{2} \mathrm{O}_{3} \quad\left(\mathrm{~F}_{1}\right)$ & 1.2 & 1.4 & 1.6 \\
\hline $\mathrm{FeO} \quad\left(\mathrm{F}_{2}\right)$ & 6.0 & 5.8 & 5.0 \\
\hline $\mathrm{CaO} \quad(\mathrm{C})$ & 23.5 & 24.7 & 24.7 \\
\hline MgO $\quad(\mathrm{M})$ & 6.9 & 6.9 & 6.9 \\
\hline $\mathrm{Na}_{2} \mathrm{O} \quad(\mathrm{N})$ & 1.4 & 1.2 & 0.2 \\
\hline $\mathrm{K}_{2} \mathrm{O} \quad(\mathrm{K})$ & 1.1 & 0.8 & 0.1 \\
\hline $\mathrm{TiO}_{2}$ & 1.1 & 1.1 & 0.9 \\
\hline Other & 0.2 & 0.2 & 0.3 \\
\hline B/A Ratio & 0.7 & 0.7 & 0.6 \\
\hline $\begin{array}{l}\text { Ferritic } \\
\text { Content, }\end{array}$ & 15 & 17 & 22 \\
\hline
\end{tabular}


TABLE XII. Relative Corrosion Resistance of Refractories Exposed to Slag Attack in Test Run 6

\begin{tabular}{|c|c|c|c|c|c|c|c|c|c|c|}
\hline \multirow[b]{2}{*}{ Number } & \multirow[b]{2}{*}{ Composition } & \multicolumn{3}{|c|}{ Depth of Removal, ${ }^{a} \mathrm{~mm}$} & \multicolumn{3}{|c|}{$\begin{array}{l}\text { Depth of Obvious } \\
\text { Penetration, }{ }^{2} \text { mm }\end{array}$} & \multicolumn{3}{|c|}{$\begin{array}{c}\text { Depth of Microstructural } \\
\text { Alteration, }{ }^{a} \mathrm{~mm}\end{array}$} \\
\hline & & $\begin{array}{l}\text { Ful1- } \\
\text { length }\end{array}$ & $\begin{array}{l}3 / 4- \\
\text { length }\end{array}$ & $\begin{array}{c}1 / 2- \\
\text { length }\end{array}$ & $\begin{array}{l}\text { Full- } \\
\text { length }\end{array}$ & $\begin{array}{l}3 / 4- \\
\text { length }\end{array}$ & $\begin{array}{l}1 / 2- \\
\text { length }\end{array}$ & $\begin{array}{l}\text { Ful1- } \\
\text { length }\end{array}$ & $\begin{array}{l}3 / 4- \\
\text { length }\end{array}$ & $\begin{array}{l}\text { 1/2- } \\
\text { length }\end{array}$ \\
\hline 2 & $\begin{array}{l}\mathrm{Al}_{2} \mathrm{O}_{3}(99.3)-\mathrm{Na}_{2} \mathrm{O}(0.4)-\mathrm{CaO}(0.1) \\
\text { (Fused-cast) }\end{array}$ & 20 & 18 & 16 & 52 & 50 & $\sim 50$ & - & - & - \\
\hline 38 & $\begin{array}{l}\mathrm{Al}_{2} \mathrm{O}_{3}(60.4)-\mathrm{Cr}_{2} \mathrm{O}_{3}(27.3)-\mathrm{MgO}(6.0) \\
-\mathrm{Fe}_{2} \mathrm{O}_{3}(4.2)-\mathrm{SiO}_{2}(1.8) \\
\text { (Fused-cast) }\end{array}$ & 10 & 8 & 9 & $\sim_{12}$ & 10 & $\sim_{10}$ & - & - & - \\
\hline 39 & $\begin{array}{c}\mathrm{MgO}(56.5)-\mathrm{Cr}_{2} \mathrm{O}_{3}(20.0)-\mathrm{Fe}_{2} \mathrm{O}_{3}(10.5) \\
-\mathrm{Al}_{2} \mathrm{O}_{3}(8.0)-\mathrm{SiO}_{2}(2.5) \\
-\mathrm{TiO}_{2}(1.5)-\mathrm{CaO}(0.5) \\
\text { (Fused-cast) }\end{array}$ & 25 & 28 & 24 & 65 & 32 & $\sim 70$ & $\sim 105$ & 118 & 295 \\
\hline 40 & $\begin{array}{c}\mathrm{MgO}(60.8)-\mathrm{Cr}_{2} \mathrm{O}_{3}(18.6)-\mathrm{Fe}_{2} \mathrm{O}_{3}(11.0) \\
-\mathrm{Al}_{2} \mathrm{O}_{3}(6.6)-\mathrm{CaO}(1.9) \\
\quad-\mathrm{SiO}_{2}(1.1) \\
\text { (Sintered) }\end{array}$ & 34 & 27 & 25 & 44 & 32 & 35 & $\sim 100$ & 70 & 40 \\
\hline
\end{tabular}

Measured from the original hot face. 


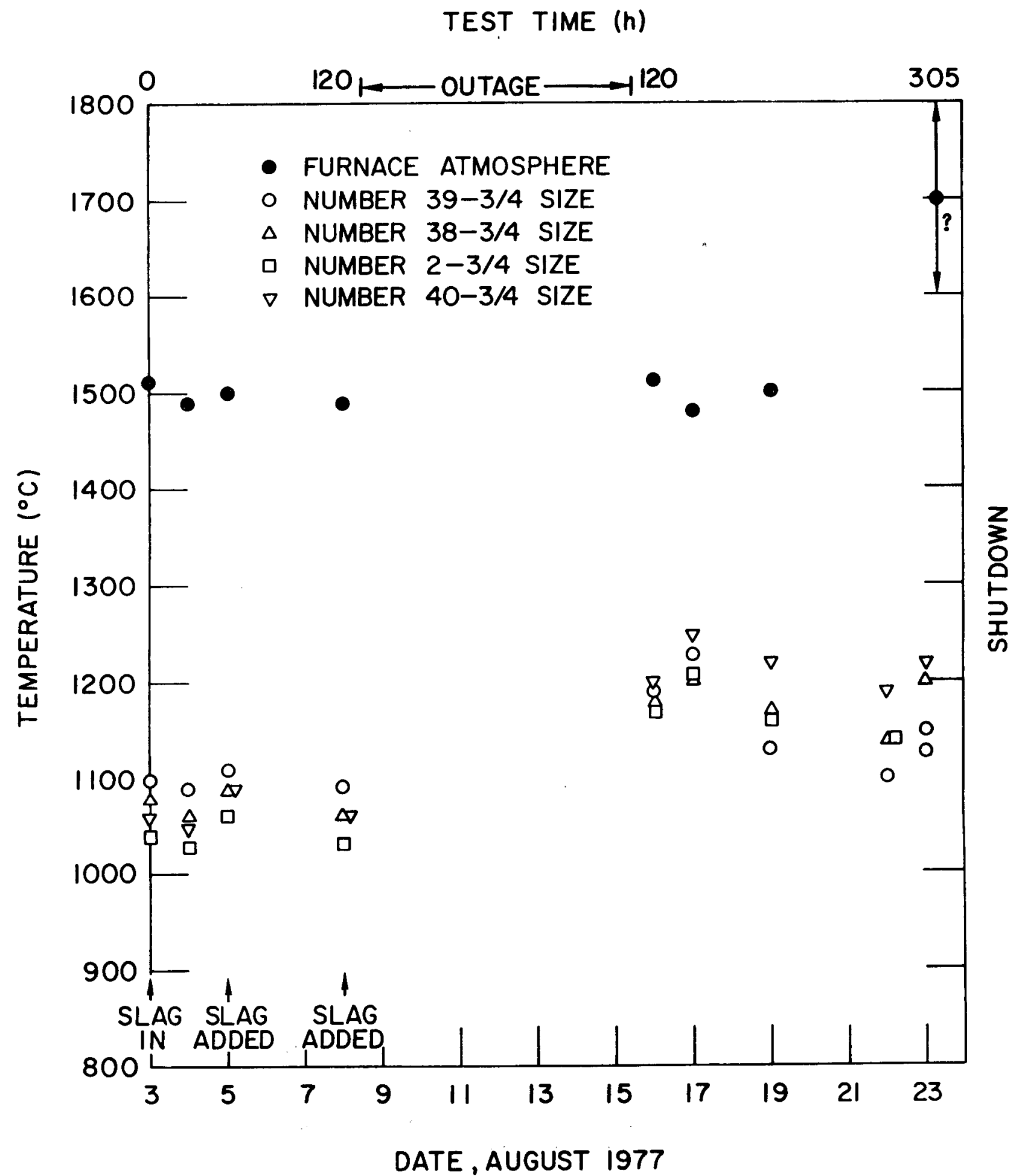

Fig. 11. Furnace Plenum Temperature and Midheight Brick Temperatures $38.1 \mathrm{~mm}$ from the Hot Face of 3/4-1ength Bricks of Each Composition During Test Run 6 . AllL Neg. No. 306-78-48. 


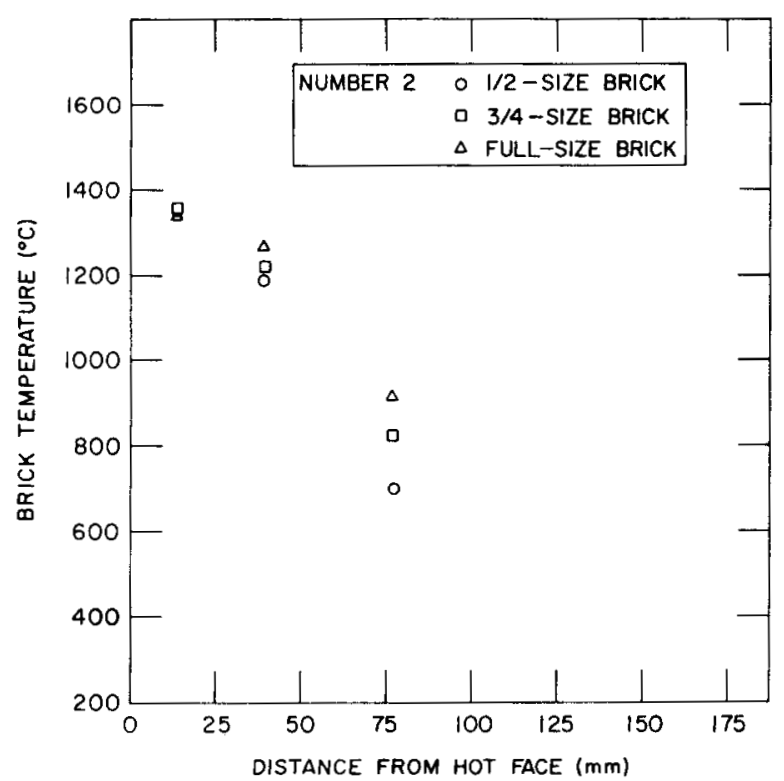

(a)

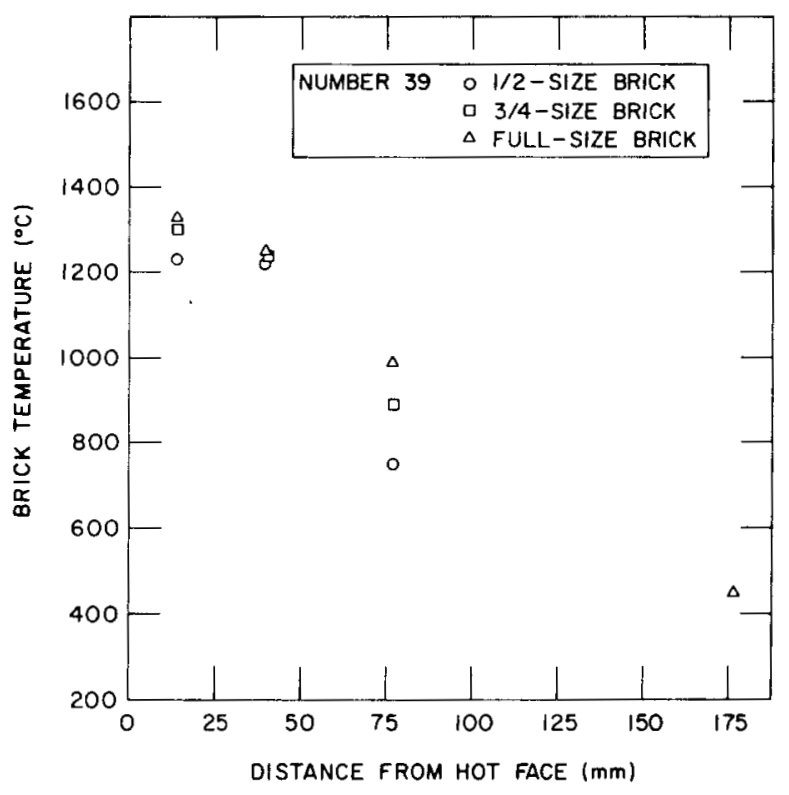

(c)

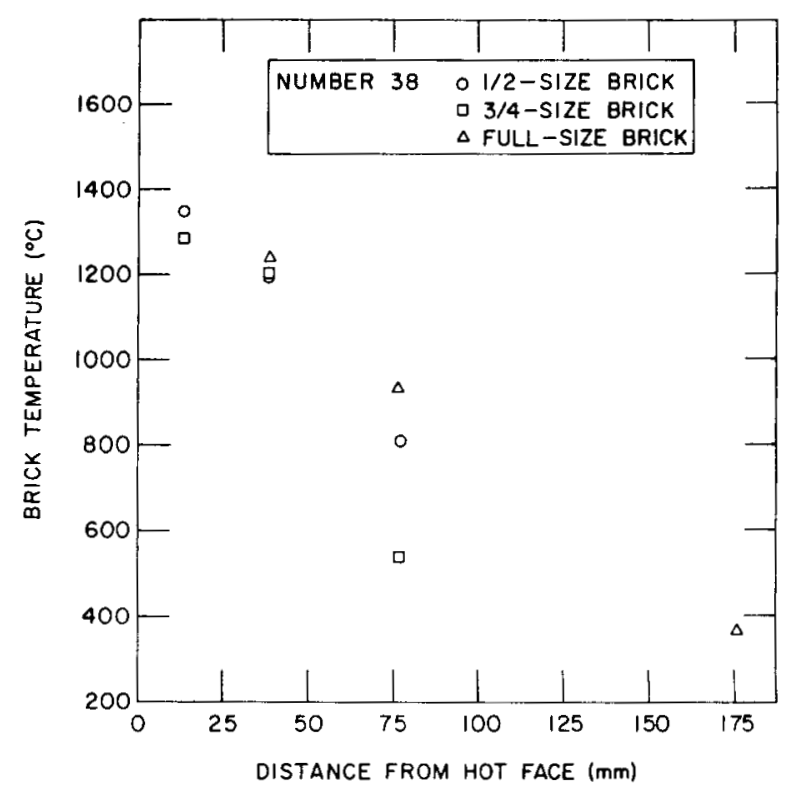

(b)

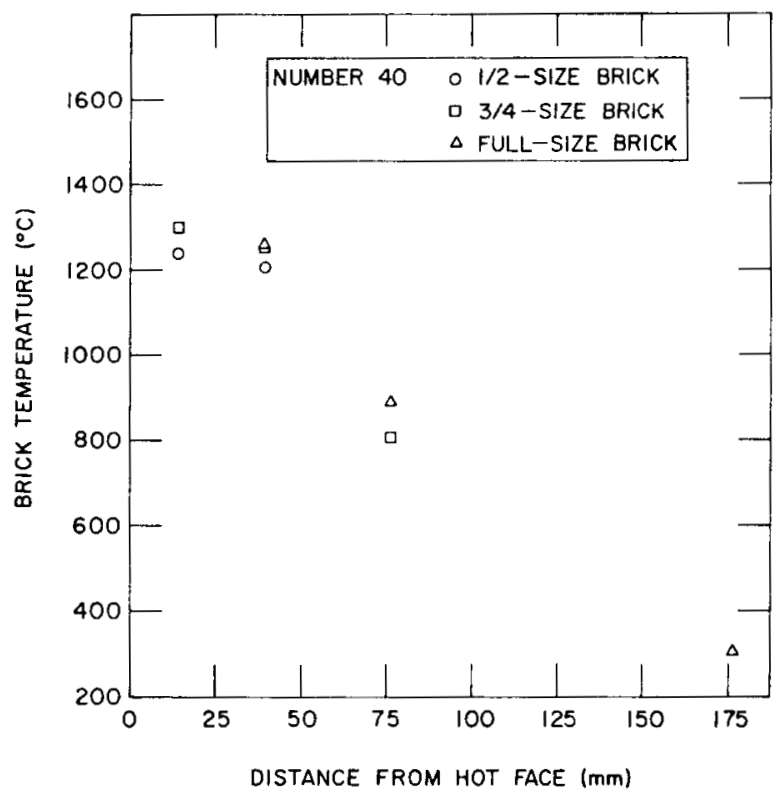

(d)

Fig. 12. Midheight Temperatures in Bricks During Test Run 6 at Four Locations in Ful1-length Bricks and at Three Locations in 3/4- and 1/2-1ength Bricks. (a) Fused-cast alumina, (b) fused-cast alumina-chrome, (c) fused-cast magnesia-chrome, and (d) compacted direct-bonded magnesia-chrome. Missing data points indicate thermocouple failures. ANL Neg. No. 306-78-40. 


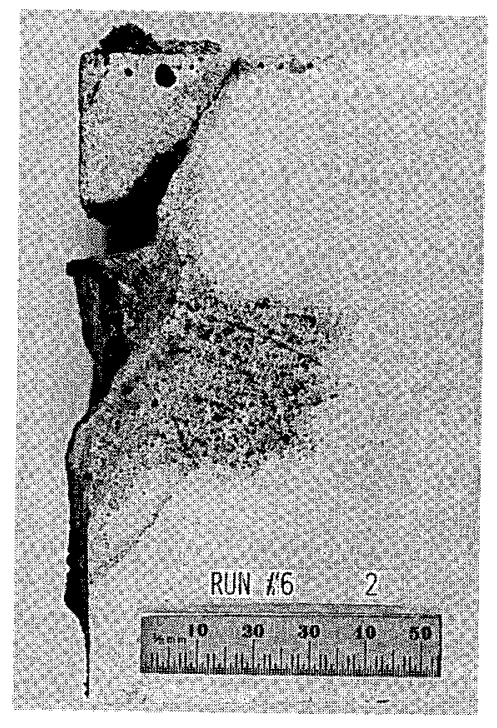

(a)

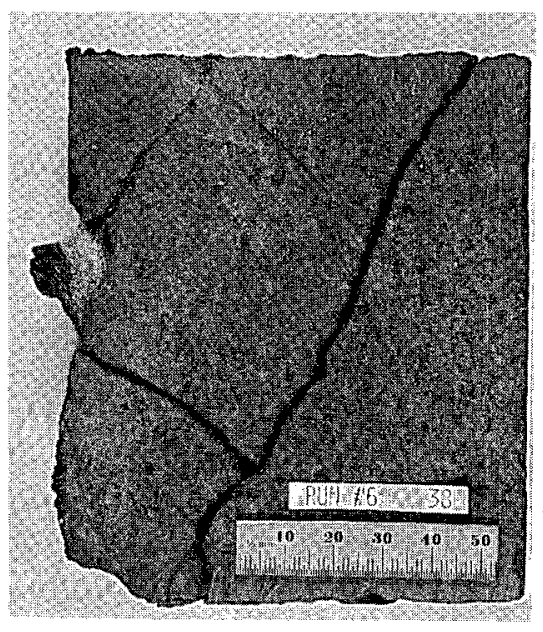

(c)

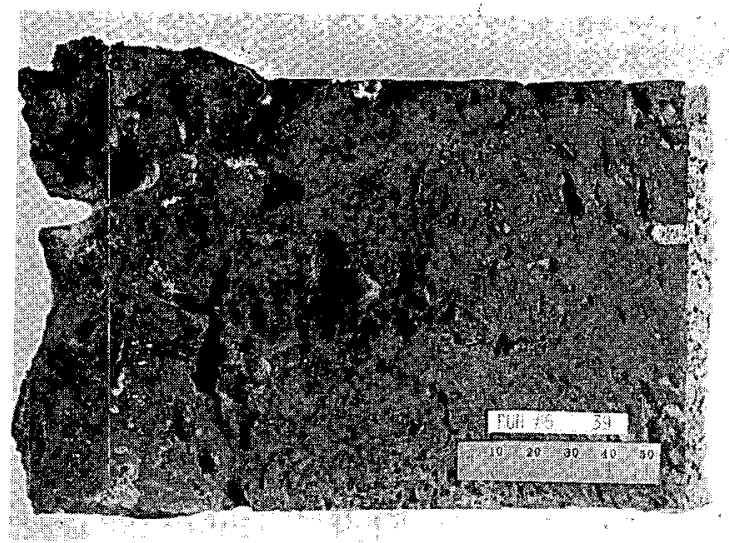

(b)

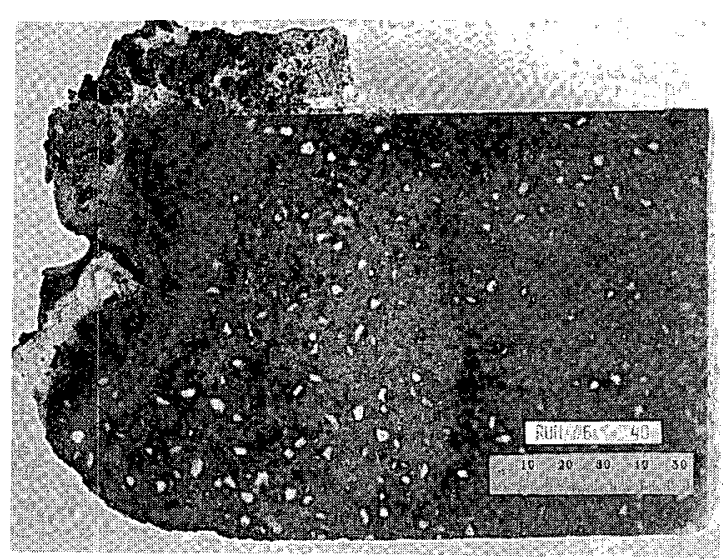

(d)

Fig. 13. Cut Sections of the 3/4-length Refractories Exposed to Slag Attack in Test Run 6. (a) Fused-cast alumina (number 2), (b) fused-cast magnesiachrome (number 39), (c) fused-cast magnesia-alumina-chrome spinel (number 38), and (d) compacted direct-bonded magnesia-chrome (number 40). The vertical face on the left-hand side of each brick was exposed to the slag. ANL Neg. No. 306-78-93. 
Test run 7 exposed alumina-chrome and alumina-silica refractories to a simulated Montana Rosebud slag, the composition of which is presented as a function of time in Table XIII. Full-, 3/4-, and 1/2-length bricks of the four refractories listed in Table XIV were first exposed to a slag pool ( $\sim 30 \mathrm{~mm}$ in depth) at $1500^{\circ} \mathrm{C}$ for $48 \mathrm{~h}$ (see Fig. 14). Additional slag was then added to the bath until it was $80 \mathrm{~mm}$ in depth, and the refractories were held at $1500^{\circ} \mathrm{C}$ for $480 \mathrm{~h}$. Oxygen partial pressure was maintained at $\sim 10^{-3} \mathrm{~Pa}$ throughout the test. The thermal profile that existed within each refractory on October 12, 1977 is shown in Fig. 15. The refractory-slag interfacial temperature was $\sim 1380-1430^{\circ} \mathrm{C}$ as determined by a pyrometer. Two lines of slag attack are visible on refractory number 17 (see arrows on Fig. 16b), the least corrosion-resistant refractory, whereas only one line of slag attack (corresponding to the exposure for $480 \mathrm{~h}$ at $1500^{\circ} \mathrm{C}$ ) is visible on the other three refractories. The two alumina-chrome refractories (numbers 23 and 852) performed the best, exhibiting only slight attack after $480 \mathrm{~h}(2-4 \mathrm{~mm}$ on fulllength bricks). These results are in contrast to those in test run 3 , in which uncooled bricks of numbers 23 and 852 performed somewhat poorly. As with the silicon carbides, the corrosion resistance of the alumina-chrome refractories improved significantly with water cooling. Comparison with results of test run 5 reveals that, when exposed to an acidic slag at a furnace plenum temperature of $1500^{\circ} \mathrm{C}$, the alumina-chrome refractories outperformed the magnesia-chrome refractories with respect to corrosion resistance. However, as a result of the thermal gradient, the front faces of the number 852 brick cracked at an $245^{\circ}$ angle to the top front edge.

Test run 8 evaluated $1 / 2-$ and full-length specimens of five raming mixes (two alumina-silica, two alumina-chrome, and one alumina-magnesia) and one sintered alumina-chrome refractory (Table XV). With the exception of the sintered refractory (number 260), wedge-shaped bricks were produced from the as-received mixes by hand ramming into a rigid mold with removable sides. Care was taken to minimize lamination of the material. Each set of bricks was dried and cured according to the manufacturer's instructions. The cured bricks were then placed in the slag-corrosion furnace and the hot face was heated to $1500^{\circ} \mathrm{C}$ for $22 \mathrm{~h}$ while the cold face was maintained at $\sim 80^{\circ} \mathrm{C}$. The furnace was then cooled to room temperature and the initial charge of slag was made (to a depth of $\sim 15 \mathrm{~mm}$ ).

Also included in this test was a $115 \mathrm{~mm} \times 64 \mathrm{~mm} \times 54 \mathrm{~mm}$ piece of refractory number 2. This specimen was placed in the slag bath near the center of the furnace and was not water cooled (Fig. 17). Its purpose was to serve as a standard by which intertest comparisons could be made. Similar specimens will be included in all future tests. 
TABLE XIII. Slag Composition During Test Run 7

\begin{tabular}{|c|c|c|c|c|}
\hline \multirow[b]{2}{*}{ Component } & \multicolumn{4}{|c|}{ Exposure Time, $\mathrm{h}$} \\
\hline & 7 & 192 & 387 & 499 \\
\hline $\mathrm{SiO}_{2}$ & $37.9^{\mathrm{a}}$ & 39.4 & 40.6 & 39.7 \\
\hline $\mathrm{Al}_{2} \mathrm{O}_{3}$ & 18.1 & 16.4 & 16.6 & 17.2 \\
\hline $\mathrm{Fe}_{2} \mathrm{O}_{3}$ & 1.3 & 3.6 & 2.9 & 3.5 \\
\hline $\mathrm{FeO}$ & 6.1 & 4.4 & 4.6 & 4.5 \\
\hline $\mathrm{CaO}$ & 25.9 & 25.8 & 26.1 & 25.6 \\
\hline $\mathrm{MgO}$ & 6.4 & 6.3 & 6.2 & 6.8 \\
\hline $\mathrm{Na}_{2} \mathrm{O}$ & 1.7 & 1.5 & 1.0 & 0.9 \\
\hline $\mathrm{K}_{2} \mathrm{O}$ & 1.4 & 1.3 & 0.7 & 0.5 \\
\hline $\mathrm{TiO}_{2}$ & 1.0 & 1.2 & 1.1 & 1.2 \\
\hline Other & 0.2 & 0.1 & 0.2 & 0.1 \\
\hline B/A Ratio ${ }^{b}$ & 0.8 & 0.8 & 0.7 & 0.7 \\
\hline $\begin{array}{l}\text { Ferritic } \\
\text { Content, b \% }\end{array}$ & 16 & 43 & 31 & 42 \\
\hline
\end{tabular}

$a_{\text {Wt }} \%$

${ }^{b}$ As in Table VII. 
TABLE XIV. Relative Corrosion Resistance of Refractories Exposed to Slag Attack in Test Run 7

TABLE XIV. Relative Corrosion Resistance of Refractories Exposed to Slag Attack in Test Run 7

\begin{tabular}{|c|c|c|c|c|c|c|c|c|}
\hline \multirow[b]{2}{*}{ Number } & \multirow[b]{2}{*}{ Composition } & \multirow[b]{2}{*}{$\begin{array}{l}\text { Attack } \\
\text { Line }\end{array}$} & \multicolumn{3}{|c|}{$\begin{array}{c}\text { Maximum Depth of } \\
\text { Removal, }{ }^{\mathrm{mm}}\end{array}$} & \multicolumn{3}{|c|}{$\begin{array}{l}\text { Maximum Depth of } \\
\text { Penetration, } \mathrm{mm}\end{array}$} \\
\hline & & & $\begin{array}{l}\text { Fu11- } \\
\text { length }\end{array}$ & $\begin{array}{l}3 / 4- \\
\text { length }\end{array}$ & $\begin{array}{c}1 / 2- \\
\text { length }\end{array}$ & $\begin{array}{l}\text { Fu11- } \\
\text { length }\end{array}$ & $\begin{array}{c}3 / 4- \\
\text { length }\end{array}$ & $\begin{array}{l}1 / 2- \\
\text { length }\end{array}$ \\
\hline 14 & $\begin{array}{l}\mathrm{Al}_{2} \mathrm{O}_{3}(91.6)-\mathrm{SiO}_{2}(8.0)-\mathrm{Fe}_{2} \mathrm{O}_{3}(0.15) \\
\text { (Sintered) }\end{array}$ & Top & 9 & 5 & 6 & 10 & 6 & 7 \\
\hline 17 & $\begin{array}{l}\mathrm{Al}_{2} \mathrm{O}_{3}(83.9)-\mathrm{SiO}_{2}(9.0)-\mathrm{Fe}_{2} \mathrm{O}_{3}(1.0) \\
-\mathrm{TiO}_{2}(2.3)-\mathrm{P}_{2} \mathrm{O}_{5}(3.6) \\
\text { (Chemically Bonded) }\end{array}$ & $\begin{array}{l}\text { Top } \\
\text { Bottom }\end{array}$ & $\begin{array}{r}13 \\
3\end{array}$ & $\begin{array}{r}11 \\
4\end{array}$ & $\begin{array}{r}11 \\
3\end{array}$ & $\begin{array}{r}17 \\
-\end{array}$ & $\begin{array}{r}16 \\
-\end{array}$ & $\begin{array}{r}14 \\
-\end{array}$ \\
\hline 23 & $\begin{array}{l}\mathrm{Al}_{2} \mathrm{O}_{3}(89.7)-\mathrm{Cr}_{2} \mathrm{O}_{3}(10.0)-\mathrm{SiO}_{2}(0.1) \\
-\mathrm{Fe}_{2} \mathrm{O}_{3}(0.1)-\mathrm{Alkali}(0.1) \\
\text { (Sintered) }\end{array}$ & Top & 4 & 2 & 2 & 7 & 7 & 6 \\
\hline 852 & $\begin{array}{l}\begin{aligned} \mathrm{Al}_{2} \mathrm{O}_{3}(81.1) & -\mathrm{Cr}_{2} \mathrm{O}_{3}(16.6)-\mathrm{P}_{2} \mathrm{O}_{5}(0.8) \\
& -\mathrm{SiO}_{2}(0.5)-\mathrm{Fe}_{2} \mathrm{O}_{3}(0.5) \\
& -\mathrm{Na}_{2} \mathrm{O}(0.5)\end{aligned} \\
\text { (Chemically Bonded) }\end{array}$ & Top & 2 & 2 & 1 & 8 & 9 & 4 \\
\hline
\end{tabular}

Measured from the original hot face. 


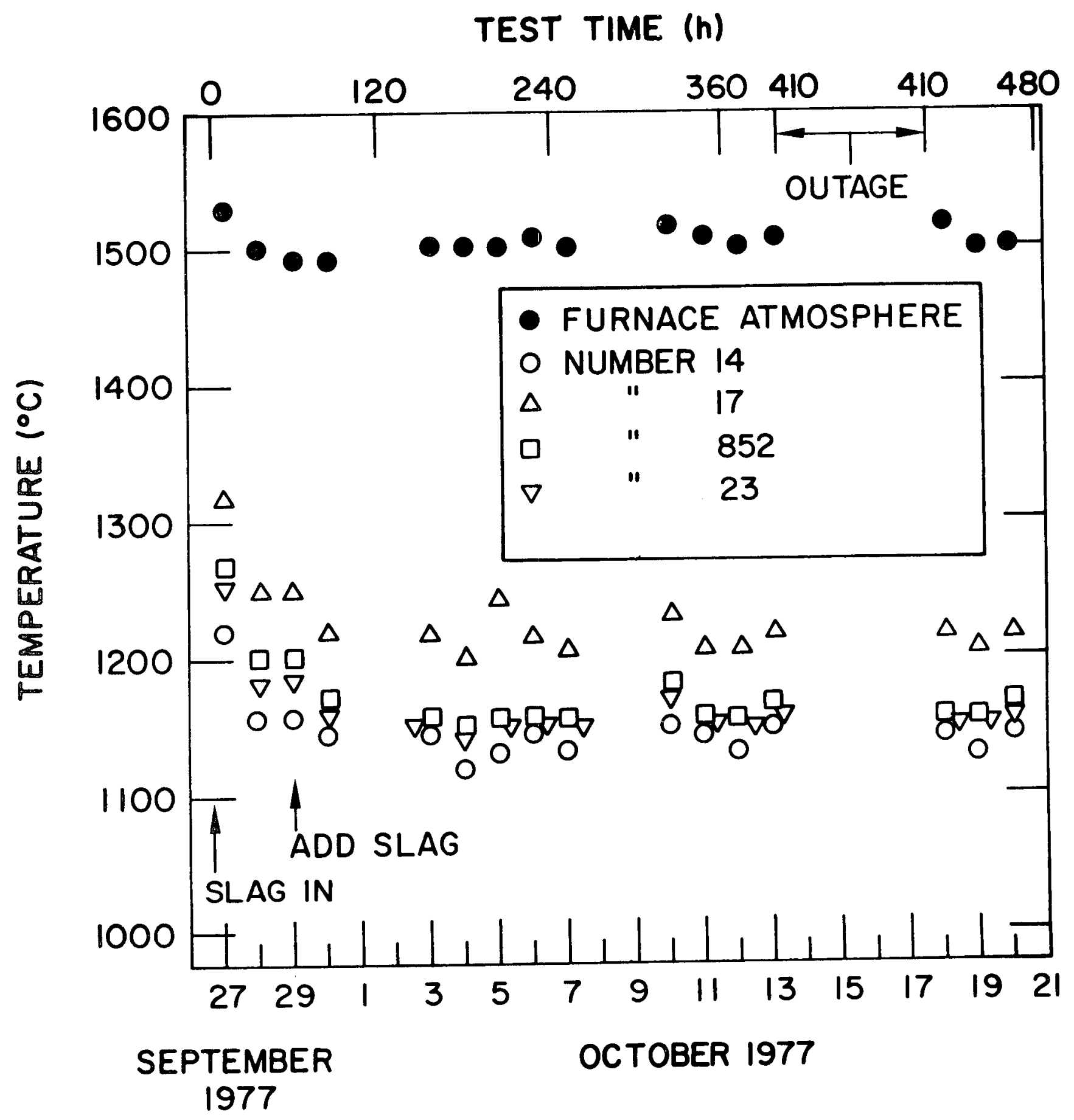

Fig. 14. Furnace Plenum Temperature and Midheight Brick Temperatures $12.7 \mathrm{~mm}$ (0.5 in.) from the Hot Face of 3/4-1ength Bricks of Each Composition During Test Run 7. ANL Neg. No. 306-78-416. 


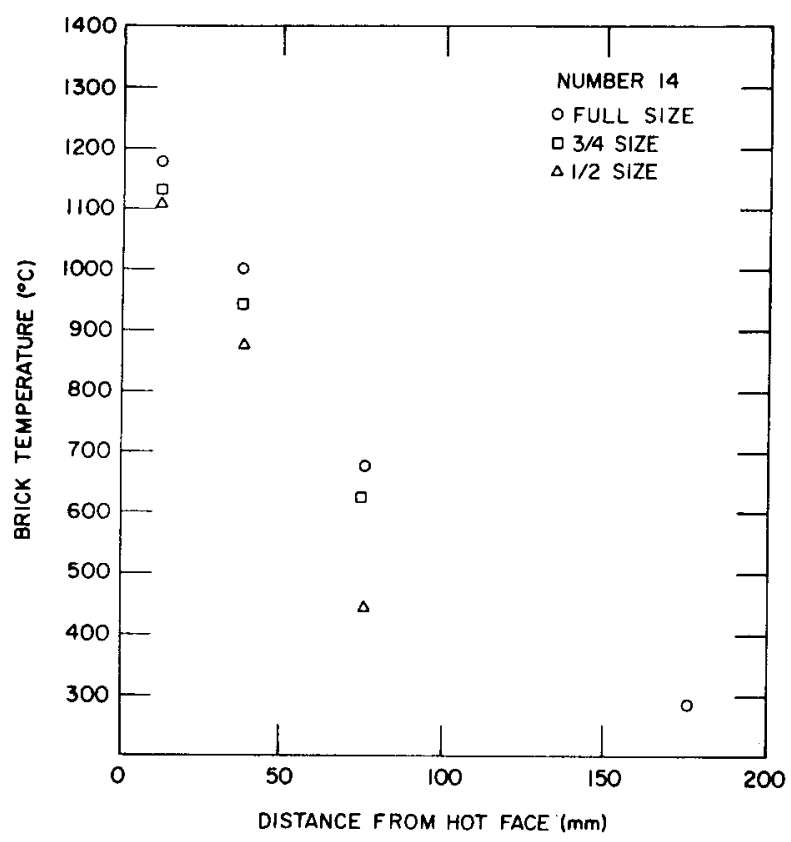

(a)

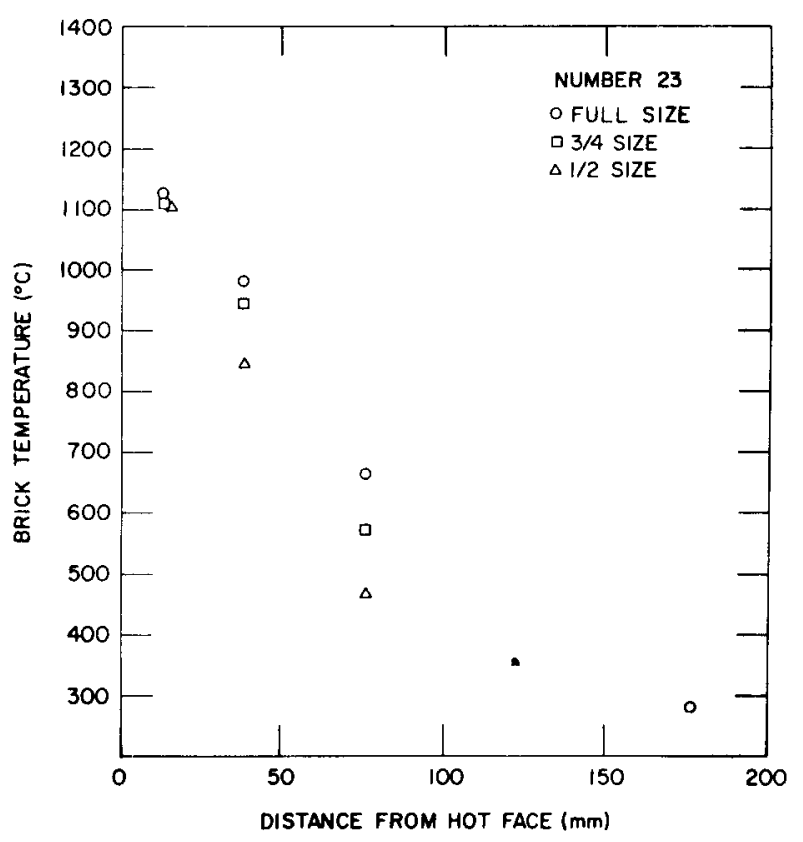

(c)

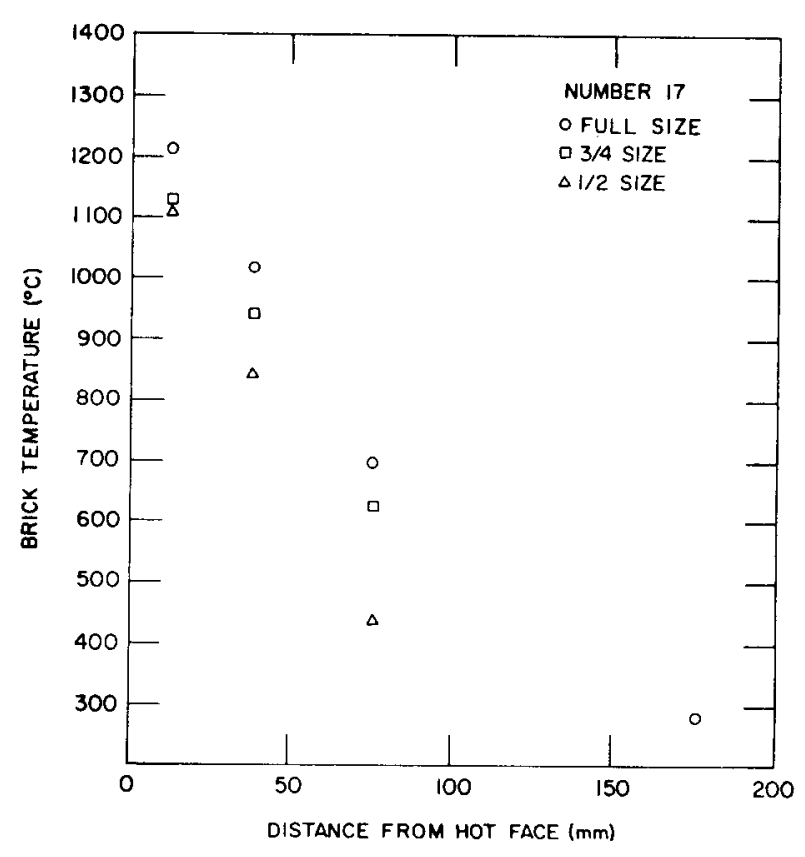

(b)

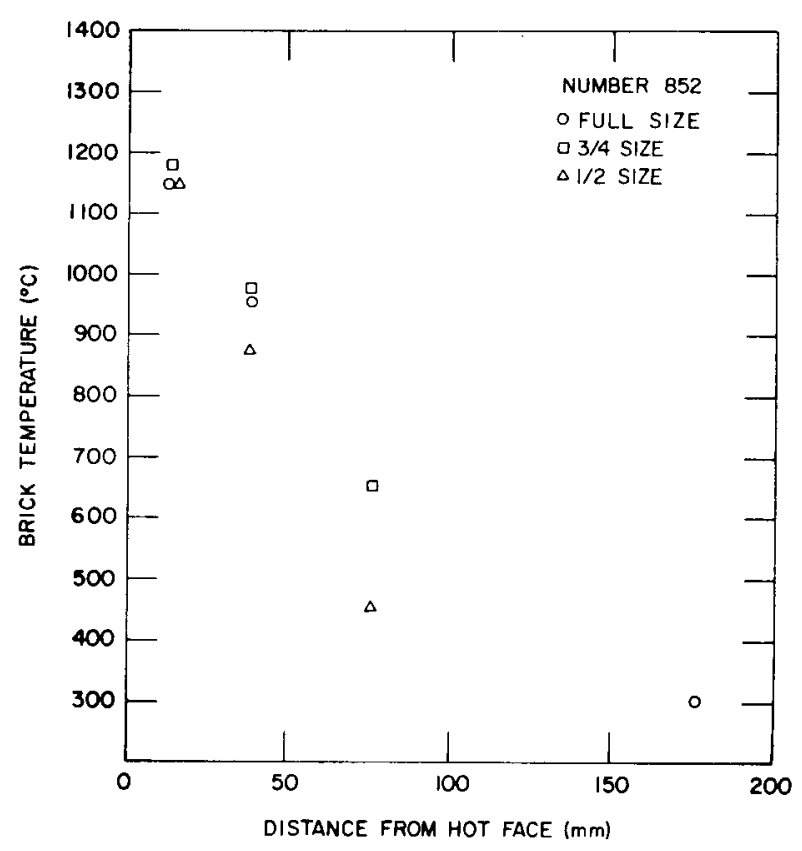

(d)

Fig. 15. Midheight Temperatures in Bricks During Test Run 7 at Four Locations in Ful1-length Bricks and at Three Locations in 3/4- and 1/2-1ength Bricks. (a) Alumina-silica (number 14), (b) alumina-silica (number 17), (c) aluminachrome (number 23), and (d) alumina-chrome (number 852). AlNL Neg. No. 306-78-768. 


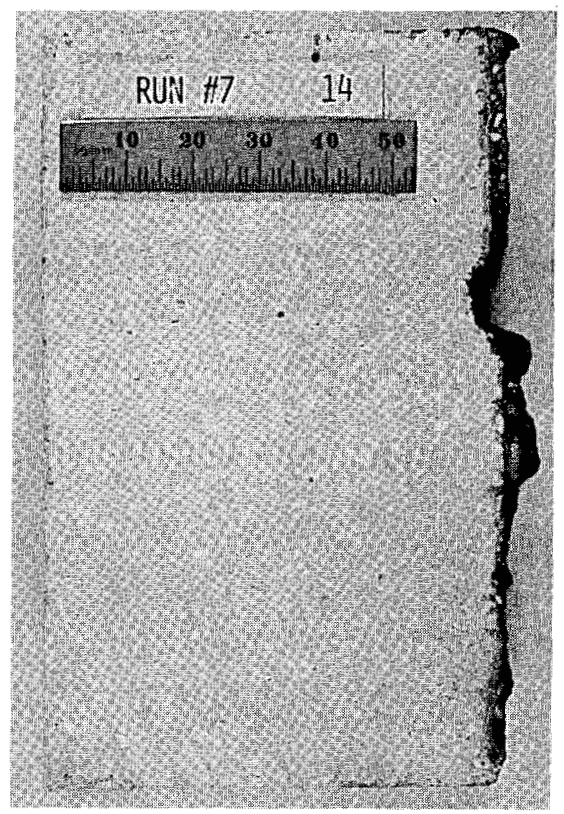

(a)

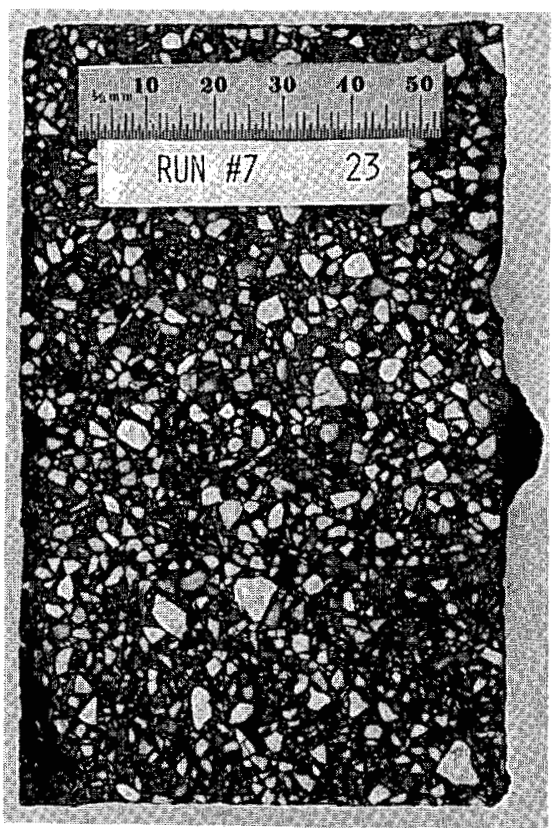

(c)

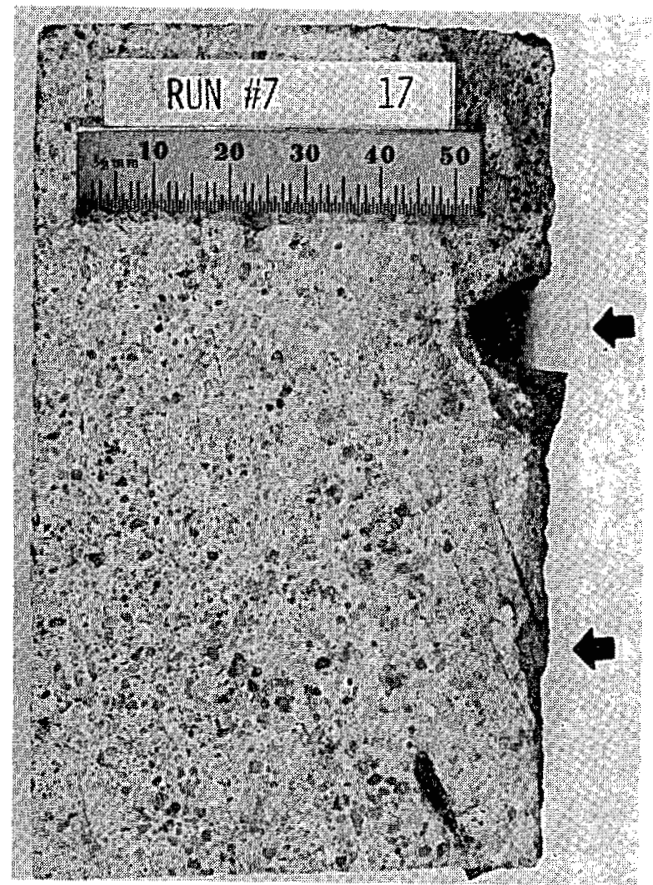

(b)

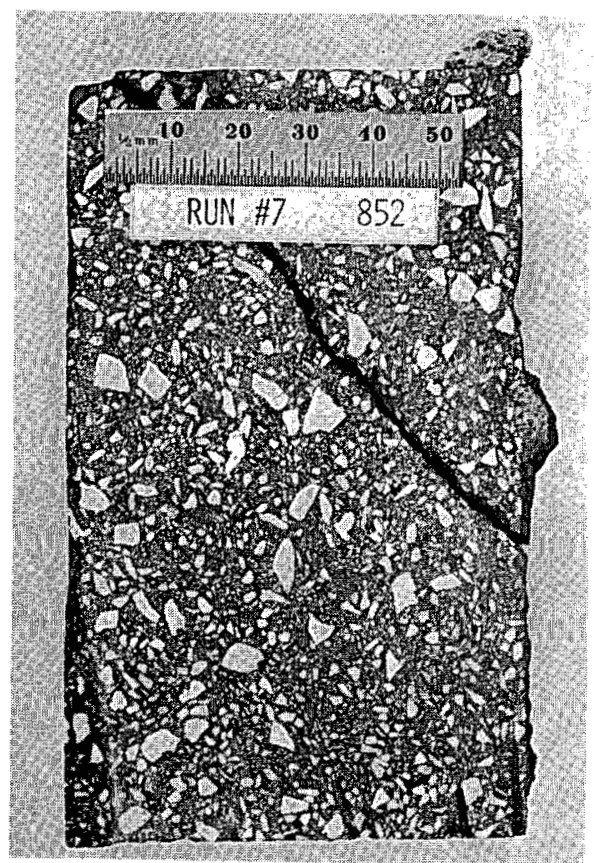

(d)

Fig. 16. Cut Sections of the 3/4-length Refractories Exposed to S1ag Attack in Test Run 7. (a) Alumina-silica (number 14), (b) alumina-silica (number 17), (c) alumina-chrome (number 23), and (d) alumina-chrome (number 852). The vertical face on the right-hand side of each brick was exposed to the slag. Two lines of slag attack are visible on brick number 17 [see arrows in (b)]. ANL Neg. No. 306-78-714. 
TABLE XV. Relative Corrosion Resistance of Refractories Exposed to Slag Attack in Test Run 8

\begin{tabular}{|c|c|c|c|c|c|c|}
\hline \multirow[b]{2}{*}{ Number } & \multirow[b]{2}{*}{ Composition } & \multirow[b]{2}{*}{$\begin{array}{l}\text { Attack } \\
\text { Line }\end{array}$} & \multicolumn{2}{|c|}{$\begin{array}{l}\text { Maximum Depth of } \\
\text { Removal, a mm }\end{array}$} & \multicolumn{2}{|c|}{$\begin{array}{l}\text { Maximum Depth of } \\
\text { Penetration, }{ }^{2} \mathrm{~mm}\end{array}$} \\
\hline & & & $\begin{array}{l}\text { Ful1- } \\
\text { length }\end{array}$ & $\begin{array}{l}1 / 2- \\
\text { length }\end{array}$ & $\begin{array}{l}\text { Ful1- } \\
\text { length }\end{array}$ & $\begin{array}{l}1 / 2- \\
\text { length }\end{array}$ \\
\hline 18 & $\begin{array}{c}\mathrm{Cr}_{2} \mathrm{O}_{3}(39.6)-\mathrm{Al}_{2} \mathrm{O}_{3}(21.4)-\mathrm{Fe}_{2} \mathrm{O}_{3}(22.6) \\
-\mathrm{MgO}(9.6)-\mathrm{SiO}_{2}(2.5) \\
-\mathrm{TiO}_{2}(0.6)-\mathrm{P}_{2} \mathrm{O}_{5}(3.7) \\
\text { (Ramming Mix) }\end{array}$ & $\begin{array}{l}\text { Top } \\
\text { Bottom }\end{array}$ & $\begin{array}{l}\sim 1 \\
\sim 1\end{array}$ & $\begin{array}{l}2 \\
?\end{array}$ & $\begin{array}{l}45 ?^{b} \\
30 ?\end{array}$ & $\begin{array}{c}30 ? \\
?\end{array}$ \\
\hline 88 & $\begin{array}{r}\mathrm{Al}_{2} \mathrm{O}_{3}(85.2)-\mathrm{Cr}_{2} \mathrm{O}_{3}(9.7)-\mathrm{SiO}_{2}(1.9) \\
-\mathrm{Fe}_{2} \mathrm{O}_{3}(0.5)-\mathrm{Na}_{2} \mathrm{O}(0.4) \\
-\mathrm{P}_{2} \mathrm{O}_{5}(2.3)\end{array}$ & $\begin{array}{l}\text { Top } \\
\text { Bottom }\end{array}$ & $\begin{array}{l}3 \\
4\end{array}$ & $\begin{array}{l}1 \\
2\end{array}$ & $\begin{array}{l}20 \\
12\end{array}$ & $\begin{array}{l}12 \\
10\end{array}$ \\
\hline 90 & $\begin{array}{l}\mathrm{Al}_{2} \mathrm{O}_{3}(89.5)-\mathrm{SiO}_{2}(6.0)-\mathrm{Alkali}(0.2) \\
-\mathrm{P}_{2} \mathrm{O}_{5}(3.7) \text {-Other }(0.6) \\
\text { (Ramming Mix) }\end{array}$ & $\begin{array}{l}\text { Top } \\
\text { Bottom }\end{array}$ & $\begin{array}{l}8 \\
9\end{array}$ & $\begin{array}{l}4 \\
7\end{array}$ & $\begin{array}{l}11 \\
14\end{array}$ & $\begin{array}{l}5 \\
8\end{array}$ \\
\hline 220 & $\begin{array}{l}\mathrm{Al}_{2} \mathrm{O}_{3}(89.6)-\mathrm{MgO}(3.4)-\mathrm{SiO}_{2}(0.7) \\
-\mathrm{P}_{2} \mathrm{O}_{5}(6.2)-\mathrm{Alkali}(0.1) \\
\text { (Ramming Mix) }\end{array}$ & $\begin{array}{l}\text { Top } \\
\text { Bottom }\end{array}$ & $\begin{array}{l}8 \\
9\end{array}$ & 7 & $\begin{array}{l}23 \\
24\end{array}$ & $\begin{array}{l}20 \\
10\end{array}$ \\
\hline 95 & $\begin{array}{l}\mathrm{Al}_{2} \mathrm{O}_{3}(95)-\mathrm{SiO}_{2}(0.2)-\mathrm{Na}_{2} \mathrm{O}(0.2) \\
\quad-\mathrm{Fe}_{2} \mathrm{O}_{3}(0.05)-\mathrm{P}_{2} \mathrm{O}_{5}(4.55) \\
\text { (Ramming Mix) }\end{array}$ & $\begin{array}{l}\text { Top } \\
\text { Bottom }\end{array}$ & $\begin{array}{r}10 \\
9\end{array}$ & $\begin{array}{r}7 \\
10\end{array}$ & $\begin{array}{l}40 \\
42\end{array}$ & $\begin{array}{l}32 \\
32\end{array}$ \\
\hline 260 & $\mathrm{Al}_{2} \mathrm{O}_{3}(67)-\mathrm{Cr}_{2} \mathrm{O}_{3}(32)$ (Sintered) & $\begin{array}{l}\text { Top } \\
\text { Bottom }\end{array}$ & $\begin{array}{l}1 \\
2\end{array}$ & $\begin{array}{l}2 \\
2\end{array}$ & $\begin{array}{c}20 ? \\
?\end{array}$ & $\begin{array}{l}? \\
?\end{array}$ \\
\hline
\end{tabular}

Measured from the original hot face.

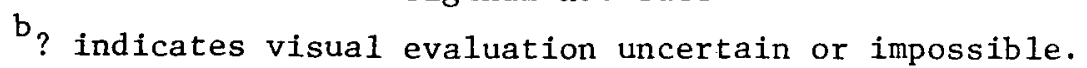




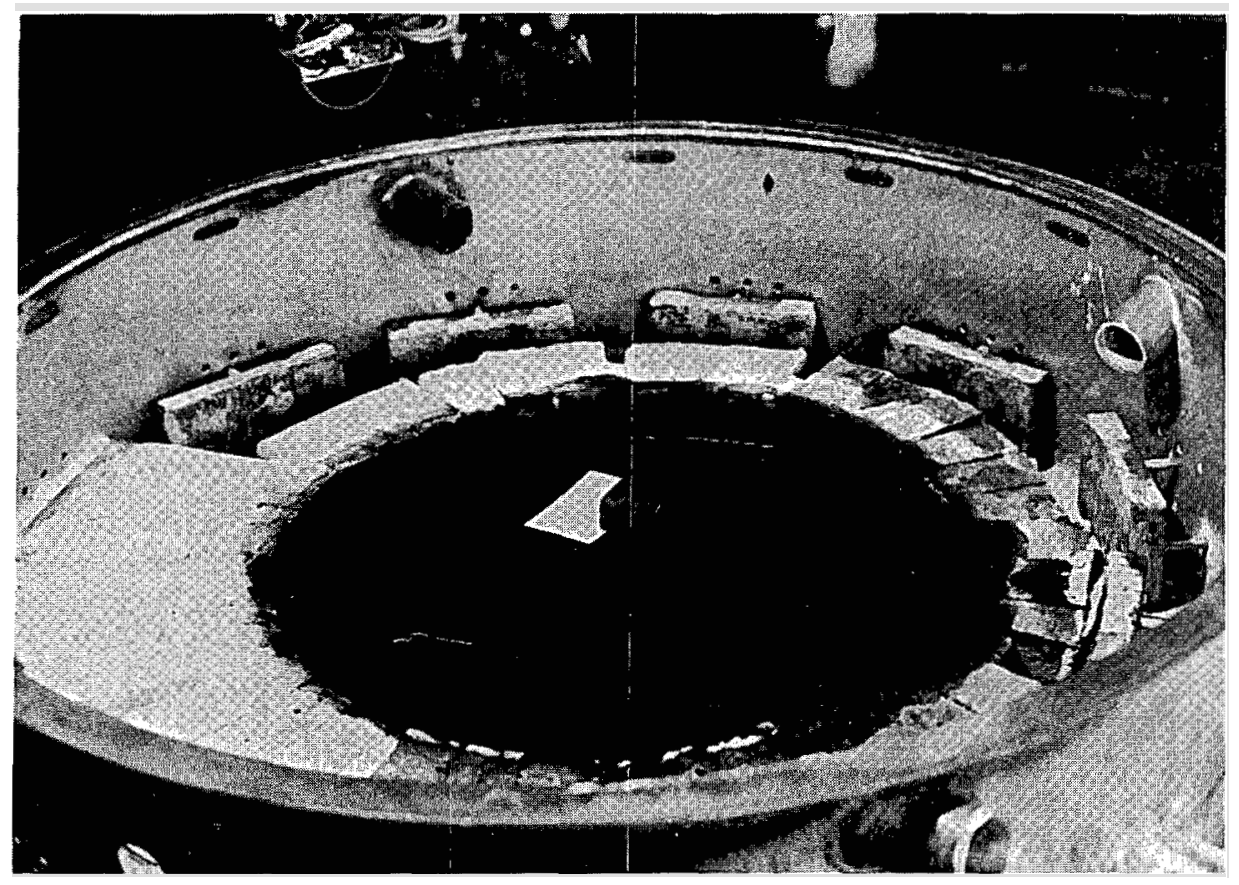

Fig. 17. Posttest Photograph Showing the Placement of the Standard Specimen of Refractory Number 2 in Test Run 8. The furnace has been partially disassembled, the insulating upper wall removed, and the cooling cans for the 1/2-size bricks detached. A $76 \mathrm{~mm} \times 127 \mathrm{~mm}$ ( 3 in. $x 5$ in.) file card has been placed next to the specimen to illustrate the depth of corrosion. ANL Neg. No. 306-78-769. 
The temperature history of run 8 is presented in Fig. 18. A simulated Montana Rosebud slag $(B / A=0.7)$ was introduced to a depth of $\sim 15 \mathrm{~mm}$, and the plenum temperature was raised to $\sim 1600^{\circ} \mathrm{C}$ for $\sim 24 \mathrm{~h}$ with a partial pressure of oxygen of $\sim 10^{-2} \mathrm{~Pa}$. The temperature of the brick-slag interface was $\sim 1550^{\circ} \mathrm{C}$. The plenum temperature was then reduced to $\sim 1500^{\circ} \mathrm{C}$ and additional slag was added to raise the level to $60 \mathrm{~mm}$. The furnace temperature was held at $1500^{\circ} \mathrm{C}$ (brick-slag interface at $1400-1430^{\circ} \mathrm{C}$ ) for $475 \mathrm{~h}$ with a partial pressure of oxygen of $\sim 10^{-3} \mathrm{~Pa}$. The temperature profiles within each refractory at midheight are shown in Fig. 19 (furnace plenum at $1610^{\circ} \mathrm{C}$ ) and Fig. 20 (furnace plenum at $1520^{\circ} \mathrm{C}$ ). Examination of the refractories and the standard reveals two lines of slag attack (Figs. 21-23). Since the vertical temperature gradient in the slag pool was steep $\left(5-10^{\circ} \mathrm{C} / \mathrm{mm}\right)$, the effect of the $475-\mathrm{h}$ hold at $1500^{\circ} \mathrm{C}$ on the bottom slag line was negligible. Thus, the bottom line of attack corresponds to $24 \mathrm{~h}$ at $1600^{\circ} \mathrm{C}$, whereas the top line of attack is the result of $475 \mathrm{~h}$ at $1500^{\circ} \mathrm{C}$. Table XV summarizes the relative resistance of the refractories tested in run 8 . The alumina-chrome compositions exhibited superior corrosion resistance, even during the short exposure at $1600^{\circ} \mathrm{C}$. Brick number 260, a sintered alumina-chrome composition, showed almost no attack, although a number of deep thermal-shock cracks developed during the test. Note in Fig. 22 that a crack parallel to the hot face (about $20-30 \mathrm{~mm}$ from it) completely separated the hotter and cooler (not shown) portions of the brick. Refractory number 18, an alumina-chrome ramming mix, also exhibited negligible corrosion but substantial cracking, which may have resulted from either thermal shock or physical growth. The other alumina-chrome ramming mix, number 88, was also very resistant to corrosion and did not crack, although it did suffer considerable penetration. The alumina-silica compositions (numbers 90 and 95) also remained free of cracks, although they suffered considerable penetration and corrosion.

Samples have been taken from the slag-refractory interface and are currently being examined, using reflected light and scanning-electron microscopes, to determine the mechanisms of attack. The results of these examinations will be published in several papers in the near future. 1-2

Further tests are planned in the slag corrosion furnace to evaluate the performance of the leading candidate materials to basic slags. Additional testing will be conducted using the plasma torch facility at ANL (Fig. 24). In this facility, samples can be exposed at temperatures up to $1700^{\circ} \mathrm{C}$ to the simultaneous effects of a dynamic flowing/frozen slag layer, erosion from slag particles that have been injected into the plasma, and to gaseous corrosion. 


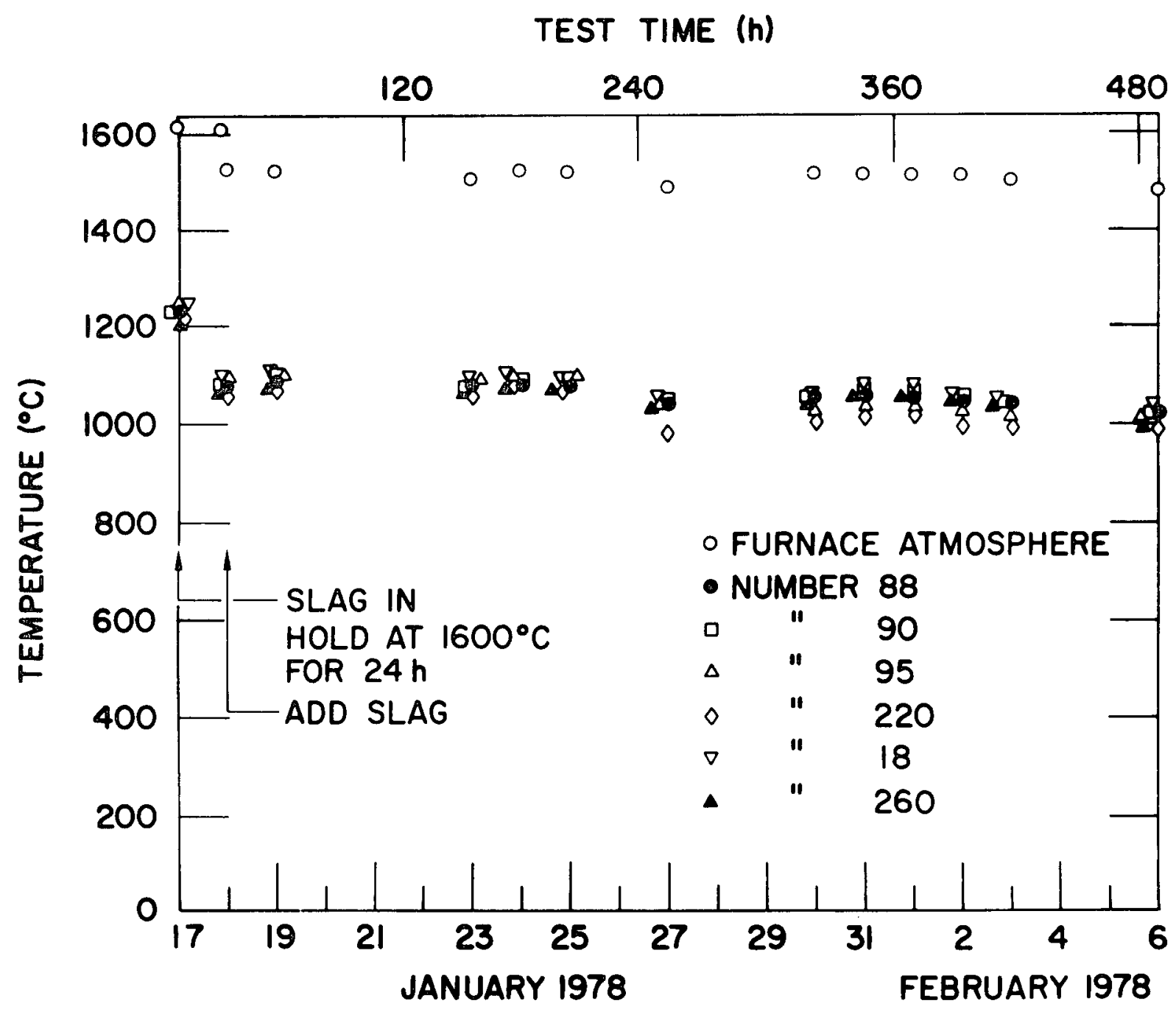

Fig. 18. Furnace Plenum Temperature and Midheight Brick Temperature $38.1 \mathrm{~mm}$ (1.5 in.) from the Hot Face of Full-size Bricks of Each Composition During Test Run 8. ANL Neg. No. 306-78-417. 

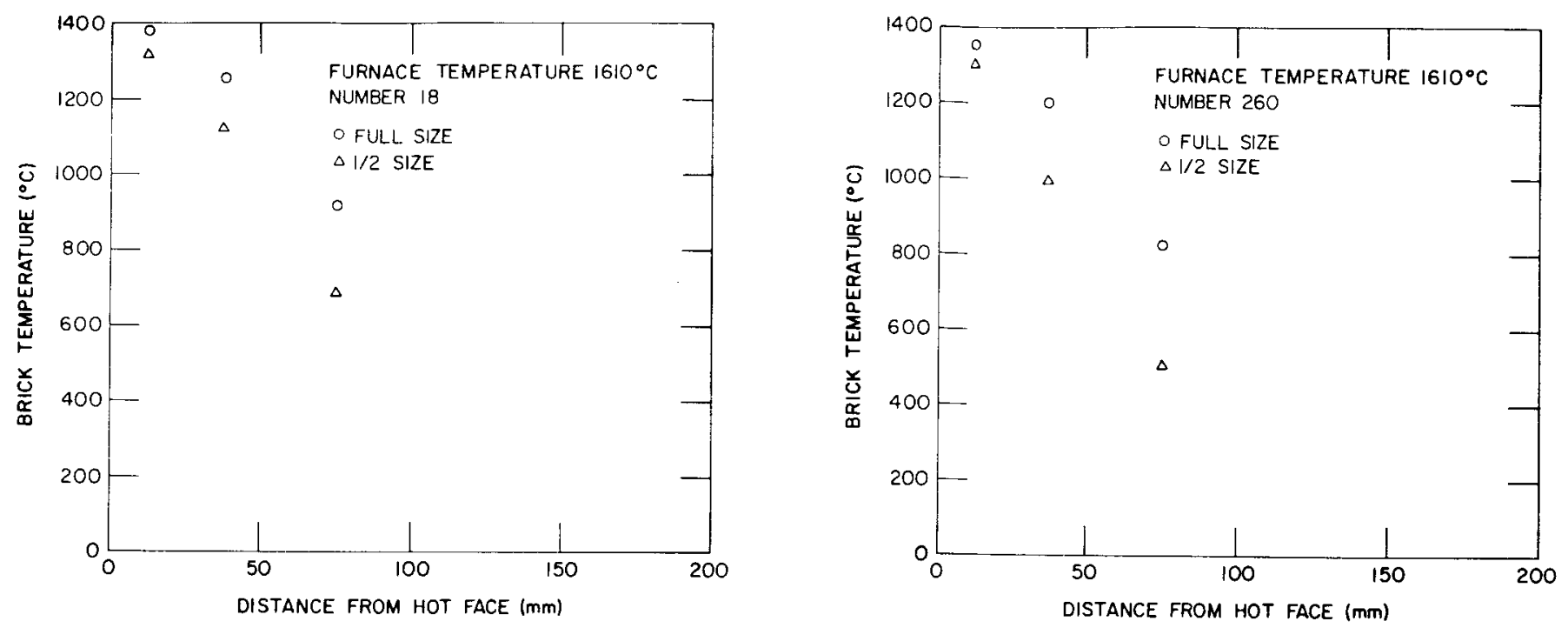

(d)

(e)

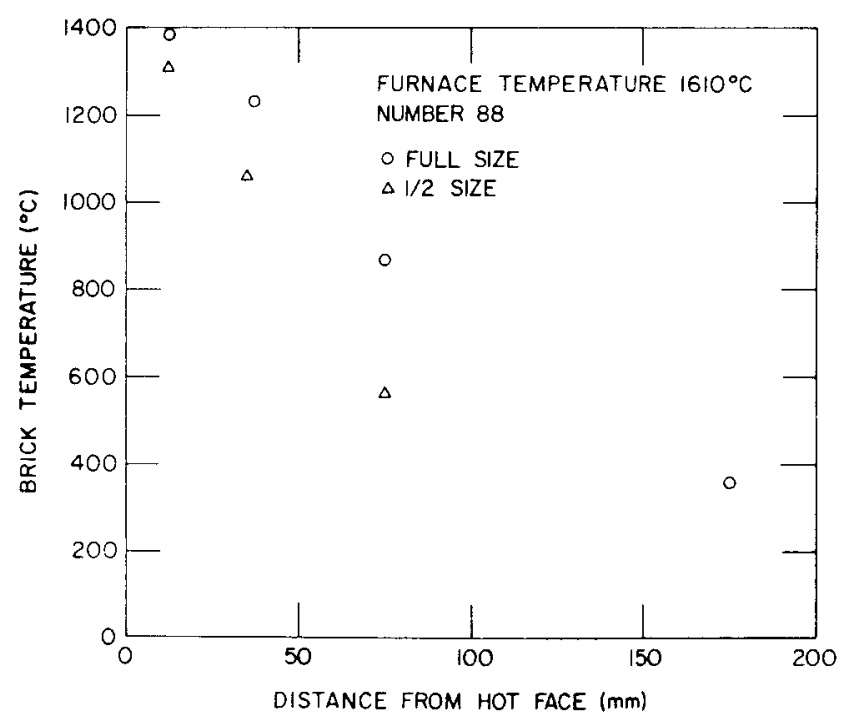

(f)

Fig. 19. Midheight Brick Temperature Versus Distance from Hot Face in Test Run 8 with Furnace Plenum Temperature $=1610^{\circ} \mathrm{C}$. (a) Number 90, (b) number 95 , (c) number 220 , (d) number 18, (e) number 260 , and (f) number 88. ANL Neg. Nos. 306-78-770 and 306-78-771. 


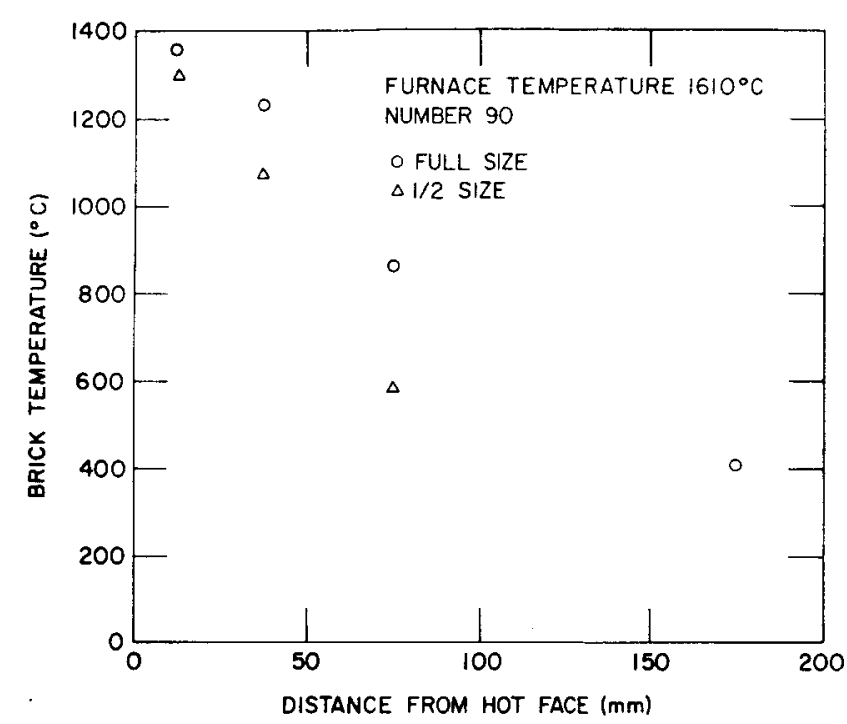

(a)

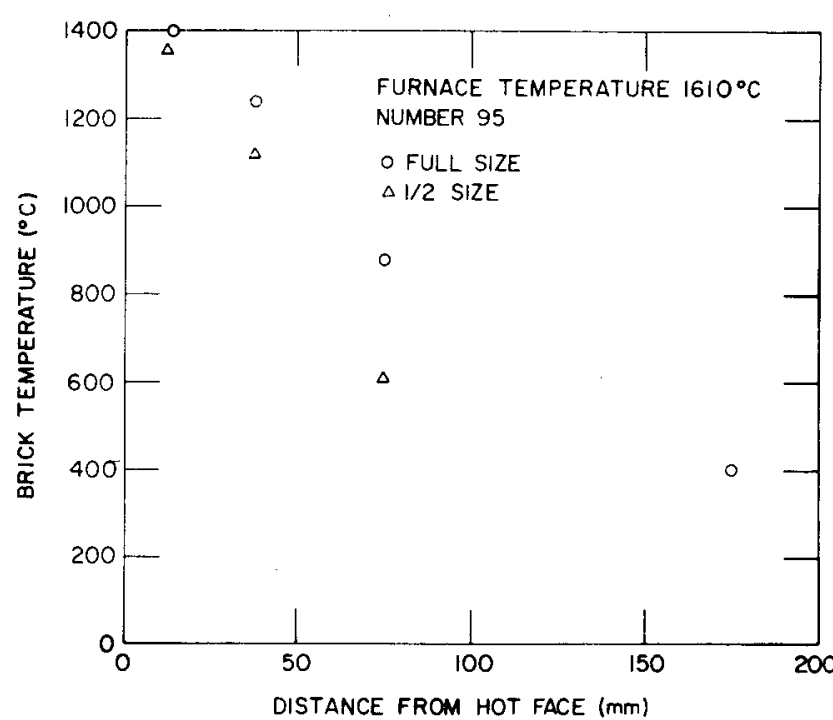

(b)

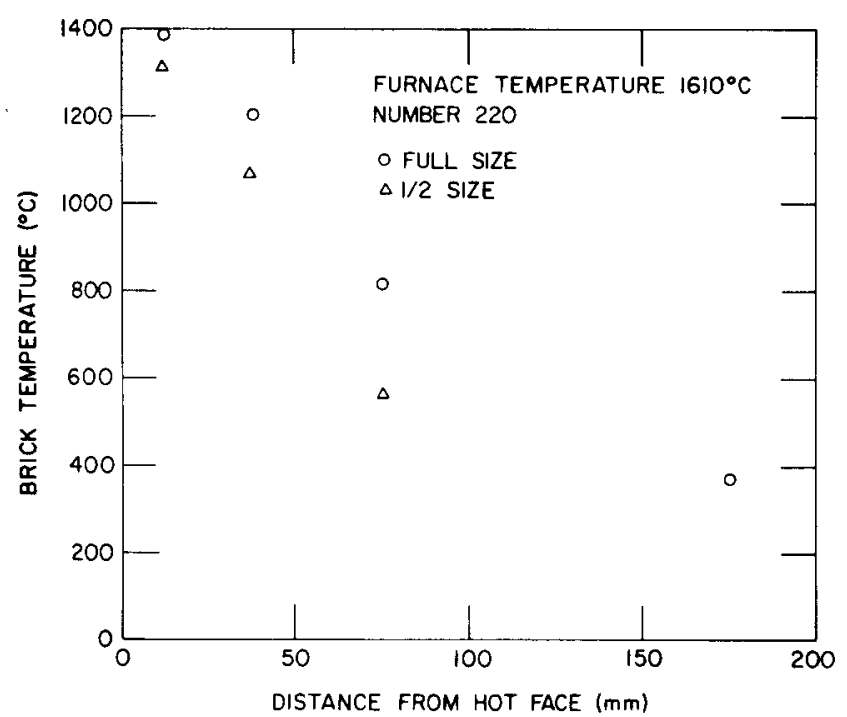

(c)

Fig. 19 (Contd.) 

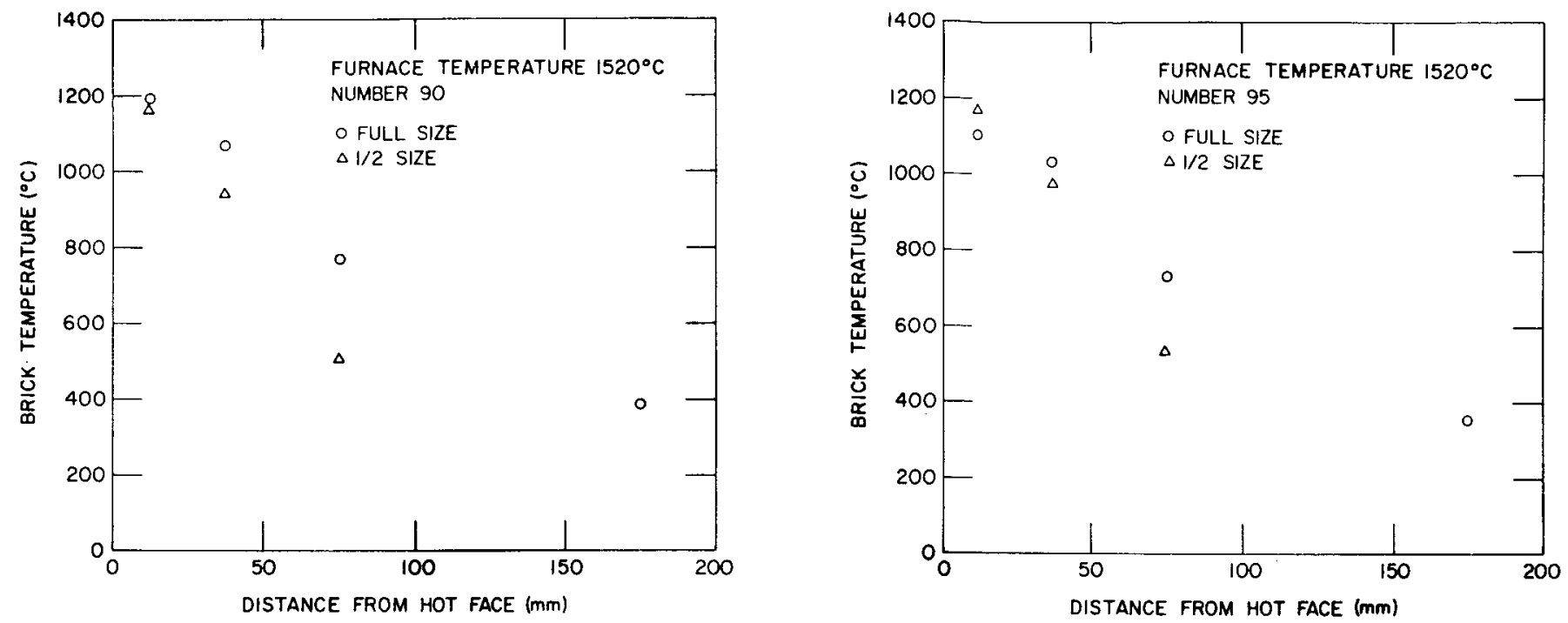

(a)

(b)

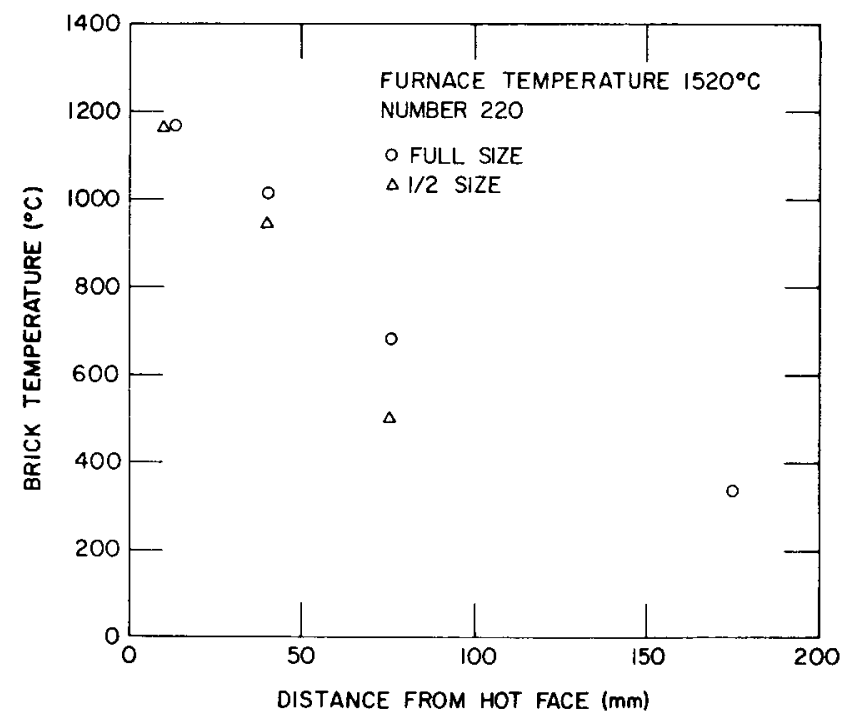

(c)

Fig. 20. Midheight Brick Temperature Versus Distance from Hot Face in Test Run 8 with Furnace Plenum Temperature $=1520^{\circ} \mathrm{C}$. (a) Number 90 , (b) number 95 , (c) number 220 , (d) number 18, (e) number 260, and (f) number 88. ANL Neg. Nos. 306-78-772 and 306-78-773. 


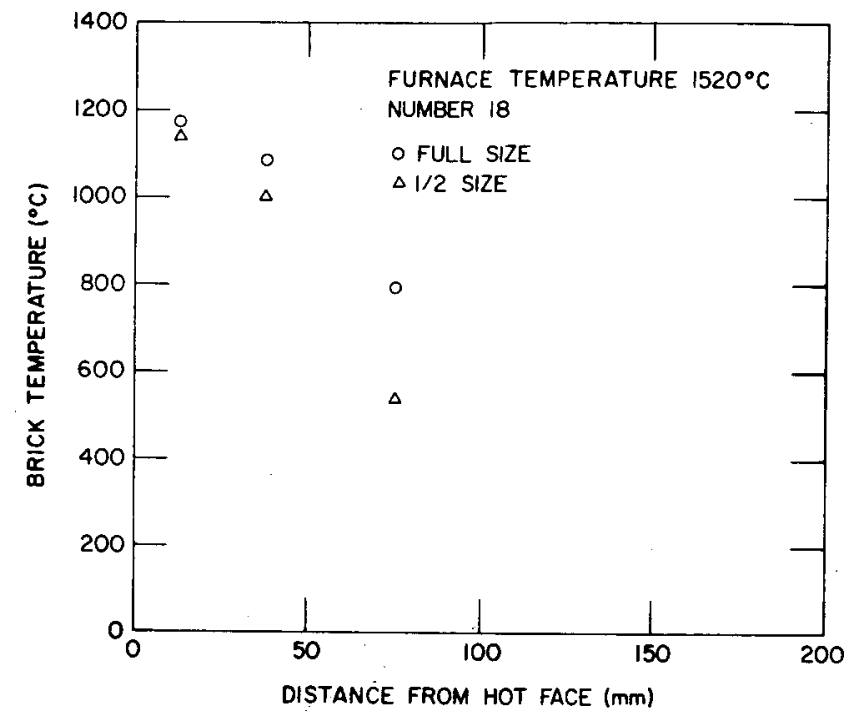

(d)

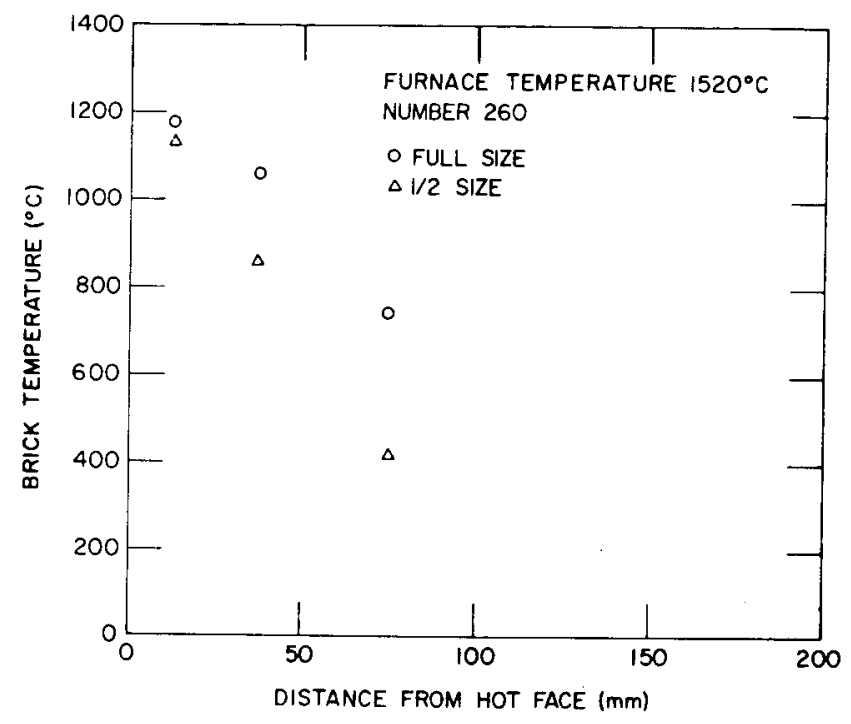

(e)

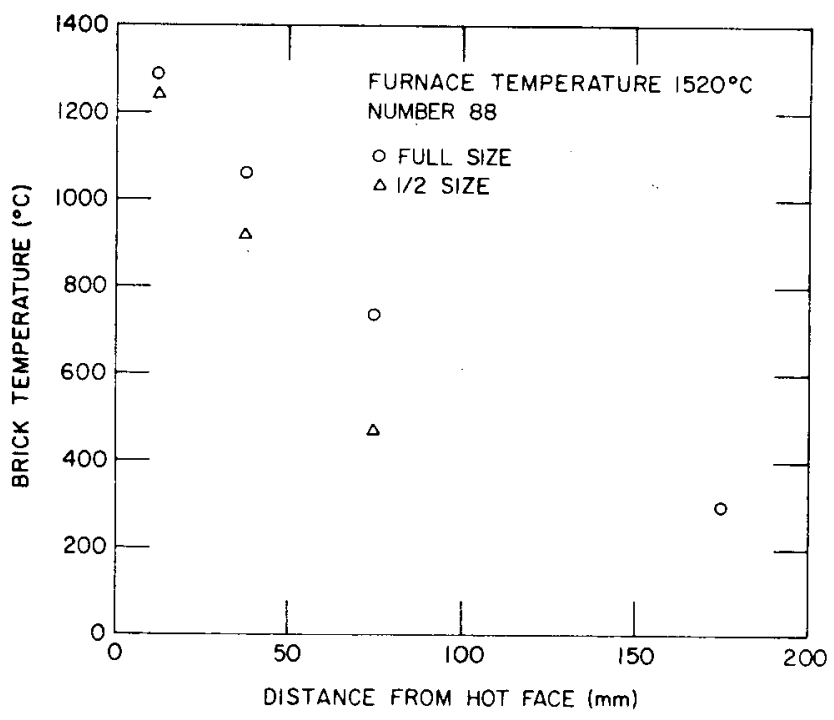

(f)

Fig. 20 (Contd.) 


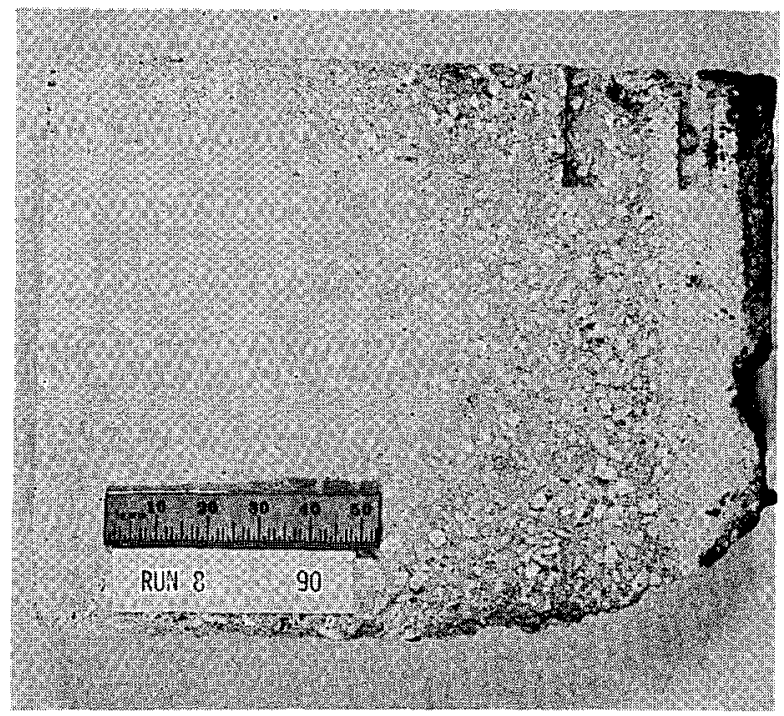

(a)

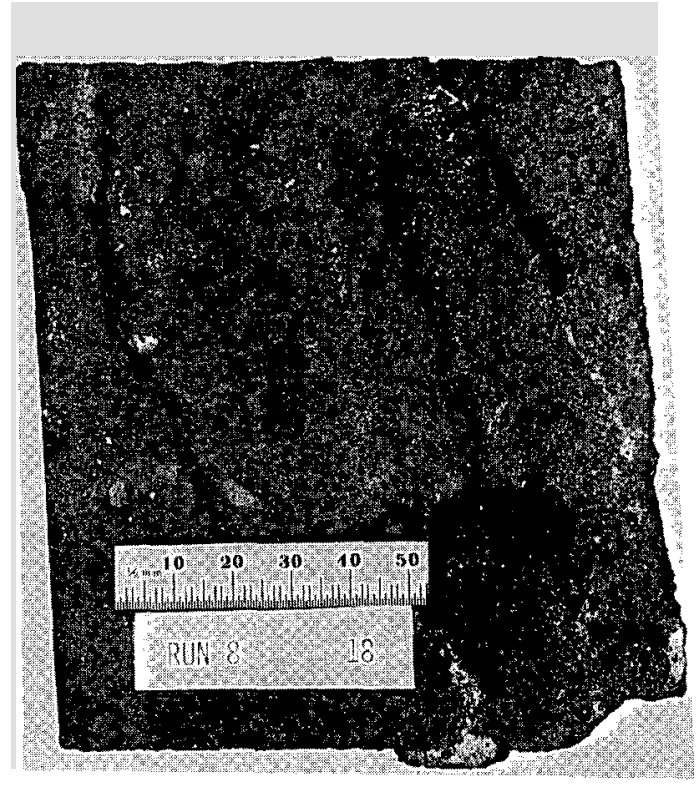

(c)

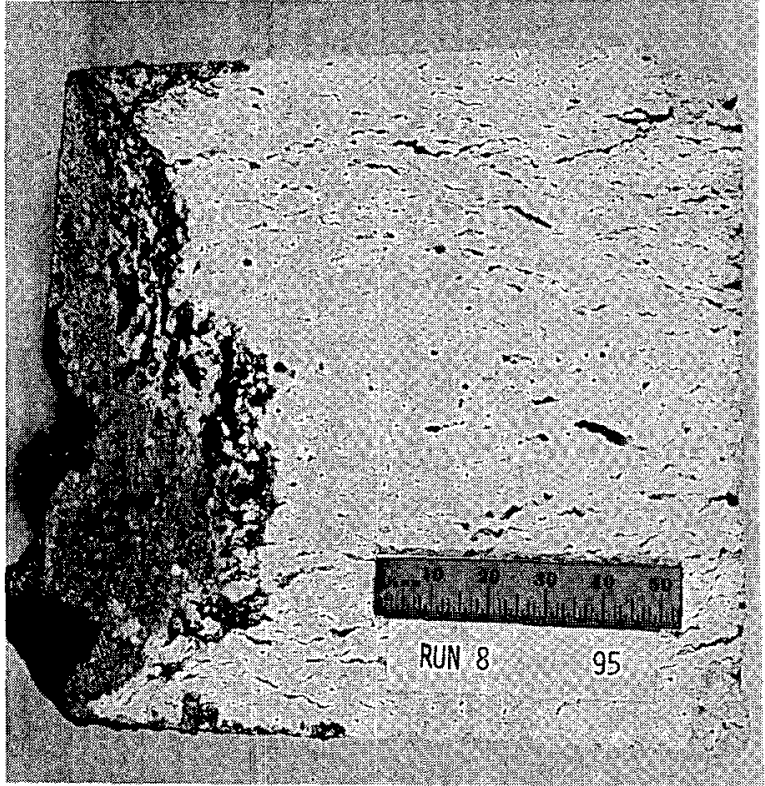

(b)

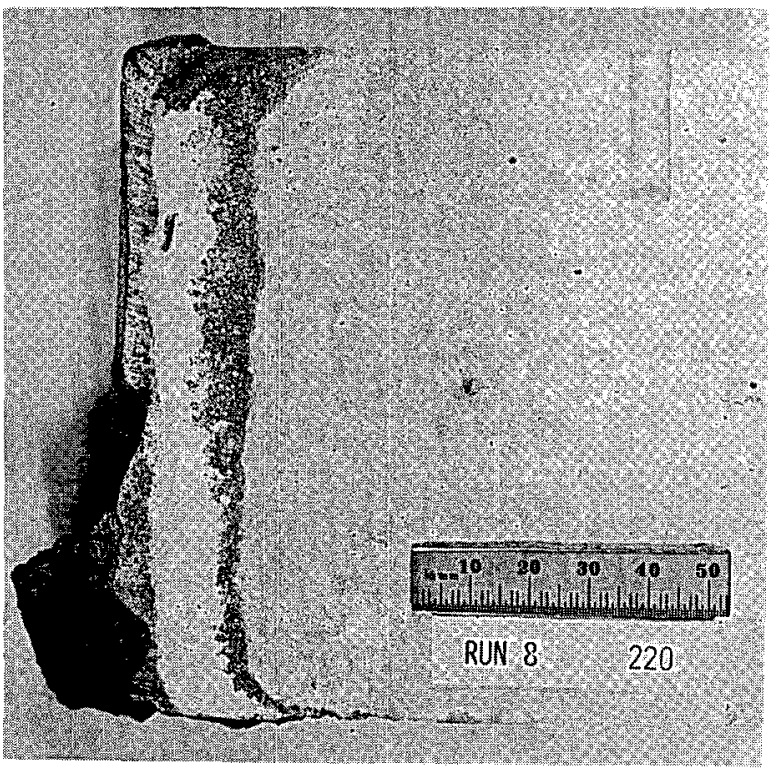

(d)

Fig. 21. Cut Sections of Ful1-length Refractories Exposed to S1ag Attack in Test Run 8. (a) Alumina-silica (number 90), (b) alumina-silica (number 95), (c) alumina-chrome (number 18), and (d) alumina-magnesia (number 220). The vertical faces toward the center of the page were exposed to two levels of slag. In (a) and (c), the bottom slag-attack zones are broken off. ANL Neg. No. 306-78-774. 


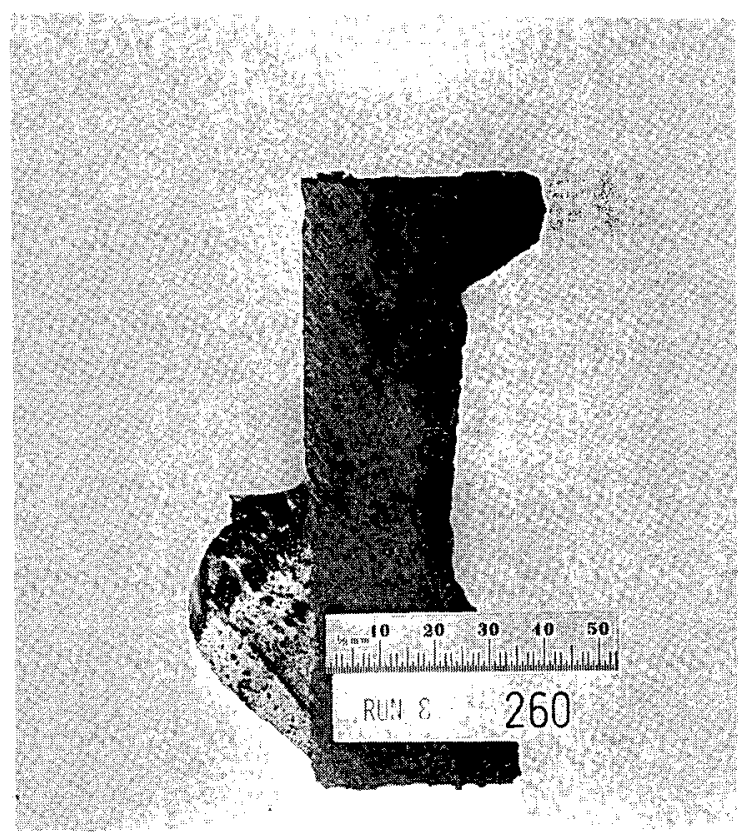

(a)

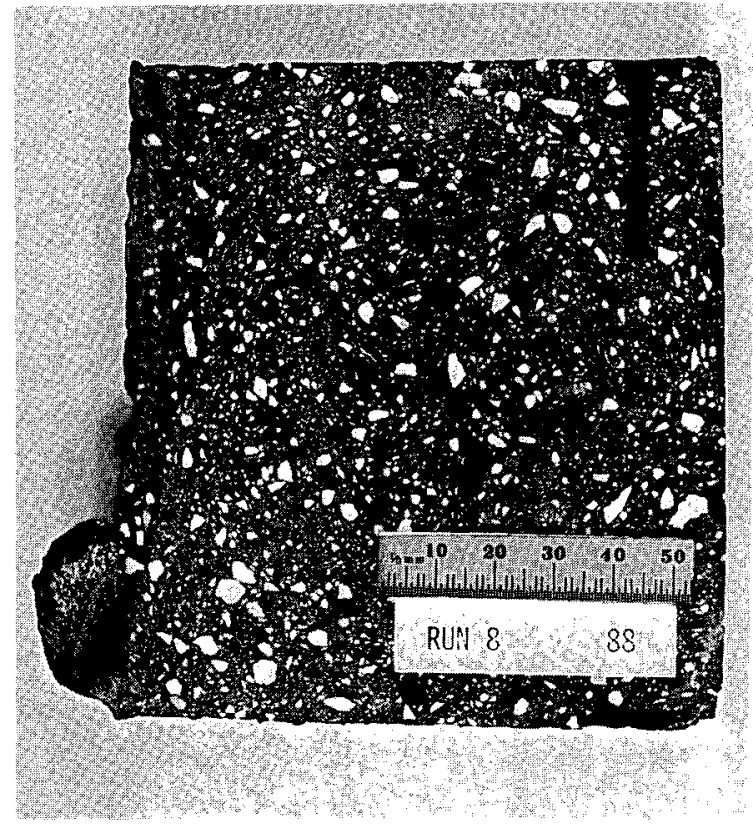

(b)

Fig. 22. Cut Sections of Refractories Exposed to Slag Attack in Test Run 8. (a) Sintered alumina-chrome (number 260) and (b) alumina-chrome (number 88). The left-hand vertical face was exposed. Number 260 fractured $\sim 20 \mathrm{~mm}$ from the hot face (the cooler section of the brick is not shown). ANL Neg. No. $306-78-775$.

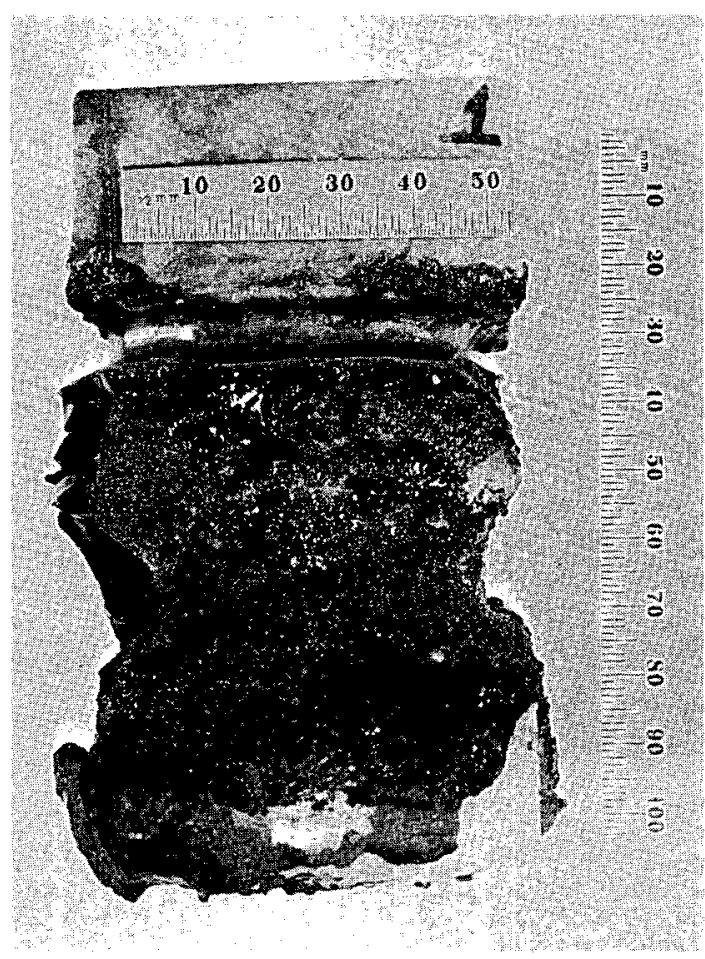

Fig. 23. Posttest Photograph of the Standard Specimen of Refractory Number 2 That Was Partially Immersed in the Slag Bath Without Water Cooling in Test Run 8. Note the two lines of slag attack extending around the specimen. ANL Neg. No. 306-78-776. 


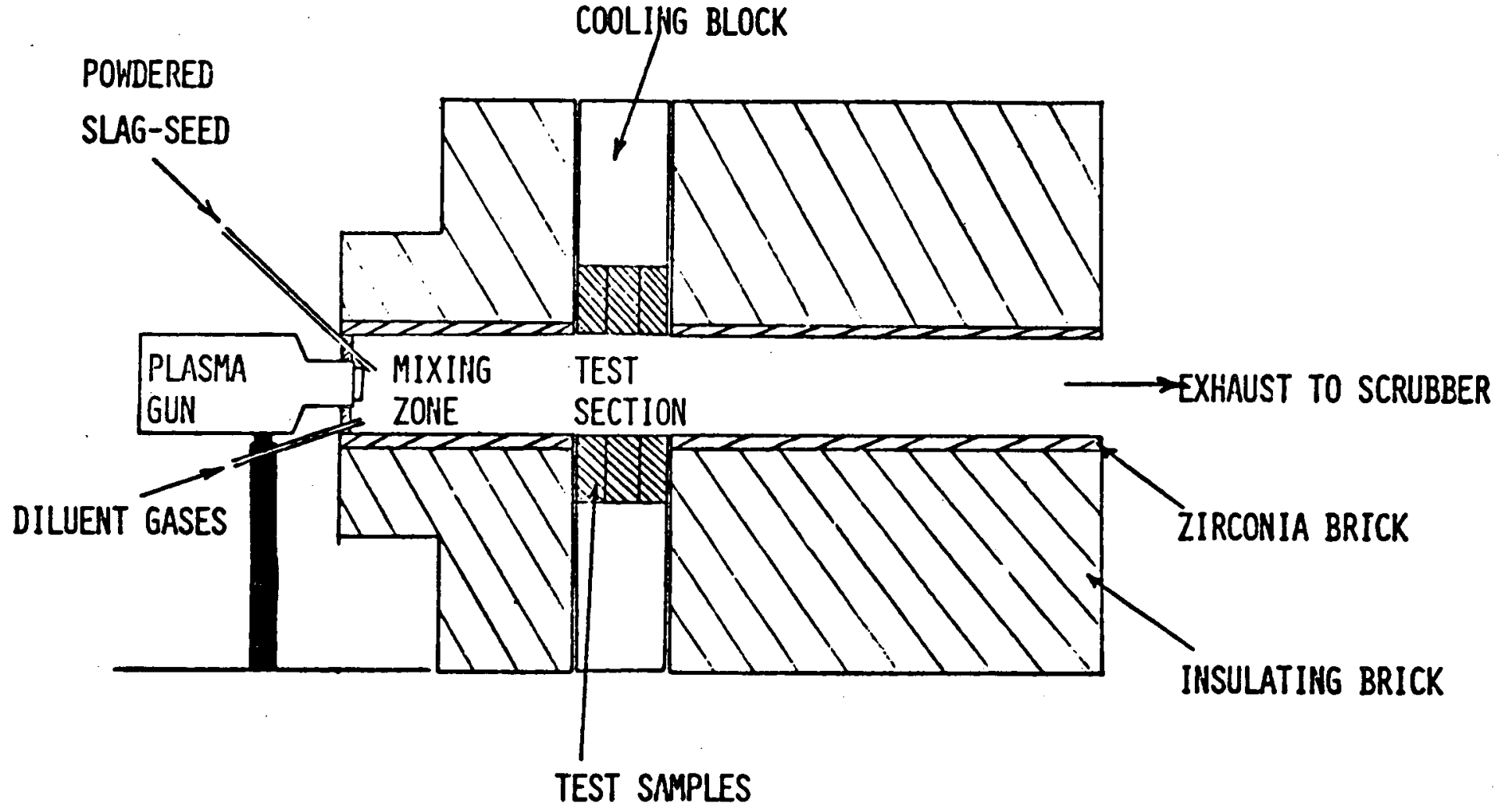

MATERIALS IESTING CHANWEL

Fig. 24. Schematic of the Plasma Torch Materials Testing Facility. Neg. No. MSD-65260. 
III. SUMMARY

The fused-cast $\mathrm{Cr}_{2} \mathrm{O}_{3}-\mathrm{MgO}-\mathrm{Fe}_{2} \mathrm{O}_{3}$ spinel refractory (number 22) exhibited superior corrosion resistance to both acidic and basic slags at $1500^{\circ} \mathrm{C}$, without water cooling. However, the thermal-shock damage resistance of this brick is questionable and the purchase cost is high ( $\$ 50$ per 9-in. straight brick). Several silicon carbide refractories have demonstrated excellent resistance to acidic slags when water cooled. Silicon carbide bricks also possess excellent thermal-shock damage resistance and are moderate in cost ( $\sim 12$ per 9 -in. straight brick). However, recent experiments ${ }^{3}$ have shown that silicon carbide refractories may not be stable in coal-gasification atmospheres if the slag layer does not provide an adequate barrier to gaseous corrosion. An additional drawback is that the extremely high thermal conductivity of these refractories, combined with the necessity for water cooling, would result in large amounts of heat loss.

Several chrome-alumina refractories (both sintered bricks and ramming mixes) have performed well in acidic slags when water cooled. Although the thermal-shock properties of sintered bricks are questionable, the ramming mixes would seem well suited for use in coal-gasification vessels, at least in patching. The cost of sintered chrome-alumina refractories is comparatively low ( $\$ 8-\$ 10$ per 9-in. straight brick) in comparison to those refractories previously mentioned, and the ramming mixes would be even less expensive.

\section{ACKNOWLEDGMENTS}

The authors gratefully acknowledge the support of $\mathrm{R}$. W. Weeks and W. A. Ellingson throughout much of this work and W. T. Bakker of the Division of Coal Conversion, Office of Fossil Energy, U. S. Department of Energy.

\section{REFERENCES}

1. C. R. Kennedy and R. B. Poeppel, "Corrosion Resistance of Refractories Exposed to Molten Acidic Coal-Ash Slags," to be published in Interceram, No. 3, September 1978.

2. J. A. Bonar, C. R. Kennedy, and R. Swaroop, "Coa1-Ash Slag Attack and Corrosion of Refractories," to be submitted to the J. Amer. Ceram. Soc. for possible publication.

3. H. Heystek and L. Y. Sadler III, "Testing and Evaluation of Refractory Linings for Coal-Gasification Equipment," presented at the First International Conference on Materials for Coal Conversion and Utilization, Gaithersburg, MD, October 11-13, 1977. 


\section{Interna1:}
B. R. T. Frost
R. G. Matlock
R. W. Weeks
T. R. Johnson
W. A. Ellingson
K. Tempelmeyer
C. R. Kennedy (50)
D. H. Killpatrick
R. Swaroop (5)
M. Petrick
D. J. Jones (5)
A. B. Krisciunas
R. J. Fousek (5)
ANL Contract File
R. B. Poeppel (5)
ANL Libraries (5)
D. Stahl (5)
TIS Files (6)

E. G. Pewitt

\section{External:}

DOE-TIC, for distribution per UC-90h (236)

Manager, Chicago Operations Office

Chief, Office of Patent Counsel, $\mathrm{CH}$

President, Argonne Universities Association

Materials Science Division Review Committee:

E. A. Aitken, General Electric Co., Sunnyvale

G. S. Ansell, Rensselaer Polytechnic Inst.

R. W. Balluffi, Massachusetts Inst. Technology

R. J. Birgeneau, Massachusetts Inst. Technology

S. L. Cooper, U. Wisconsin

C. Laird, U. Pennsylvania

M. T. Simnad, General Atomic

C. T. Tomizuka, U. Arizona

A. R. C. Westwood, Martin Marietta Labs. 